\author{
ZENTRUM \\ FÜR BIODIVERSITÄT UND NACHHALTIGE LANDNUTZUNG \\ SEKTION \\ BIOdIVERSITÄT, ÖKOLOGIE UND NATURSCHUTZ \\ - Centre of Biodiversity ANd Sustainable LAND USE - \\ SECTION: BIOdIVERsity, Ecology ANd Nature Conservation
}

\title{
Structure of and carbon flux through soil food webs of temperate grassland as affected by land use management
}

\author{
Dissertation zur Erlangung des Doktorgrades der \\ Mathematisch-Naturwissenschaftlichen Fakultäten der \\ Georg-August-Universität Göttingen
}

\author{
vorgelegt von \\ Diplom-Biologin \\ Kathleen Lemanski \\ aus \\ Lüneburg
}

Göttingen, September 2014 
Referentin/Referent: Prof. Dr. Stefan Scheu

Korreferentin/Korreferent: PD Dr. Mark Maraun

Tag der mündlichen Prüfung: 


\section{Table of contents}

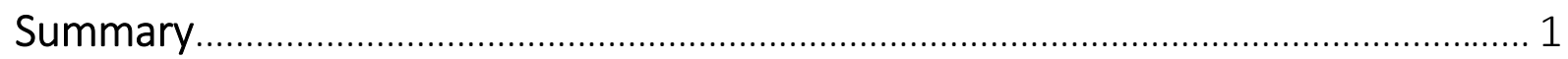

\section{|Chapter 1}

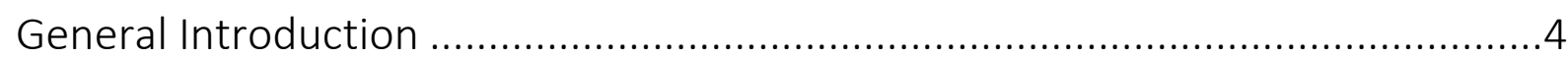

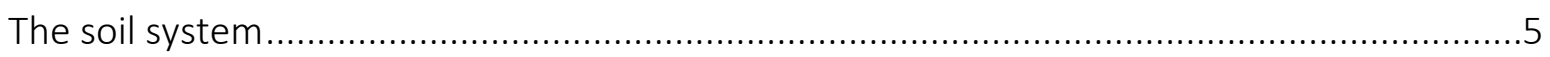

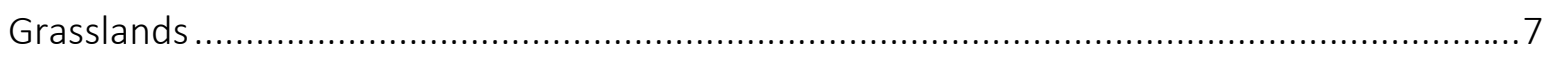

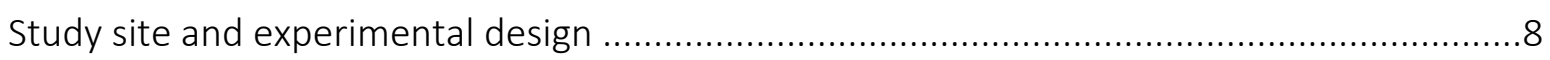

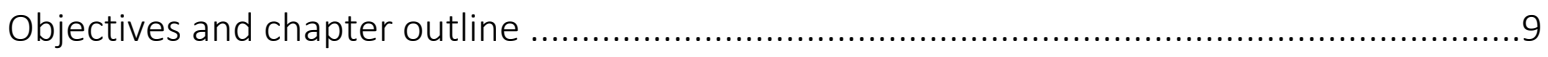

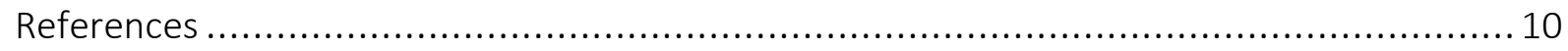

\section{|Chapter 2}

Influence of fertilizer addition, cutting frequency and herbicide application on

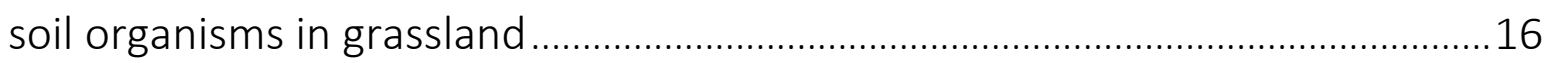

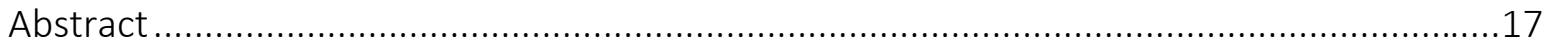

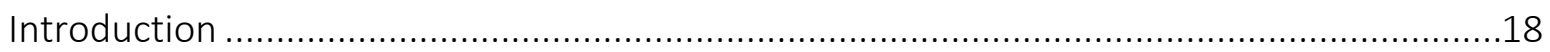

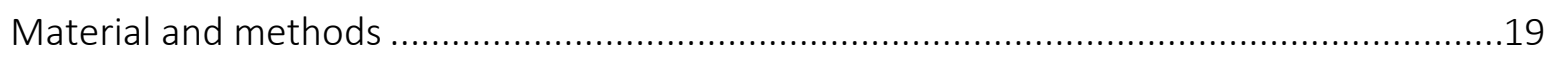

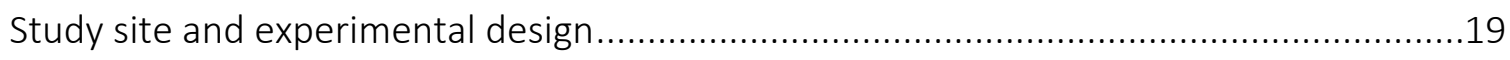

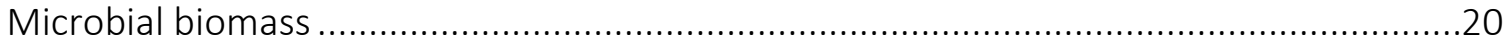

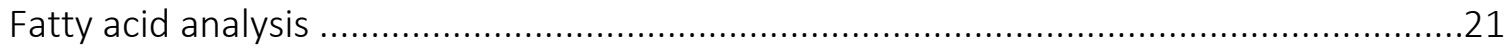

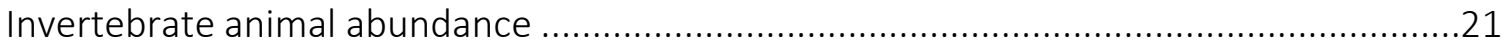

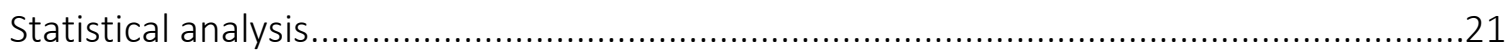

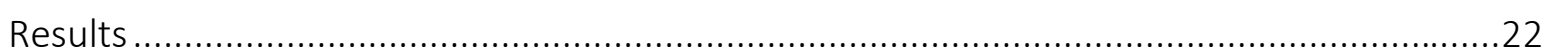

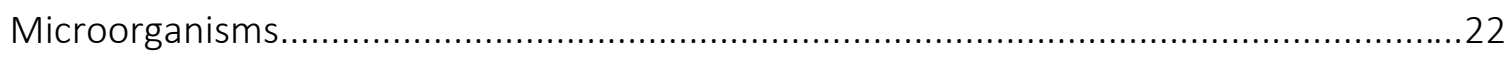

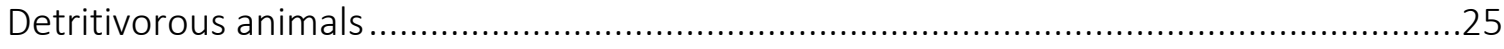

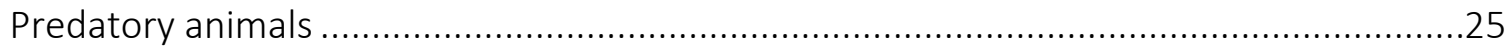

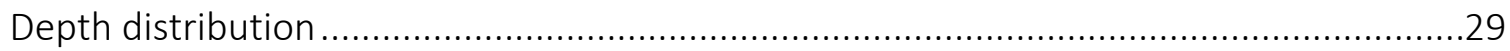

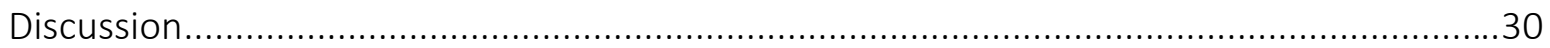

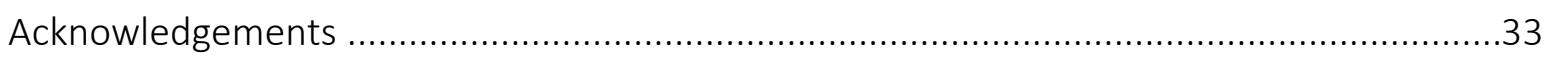

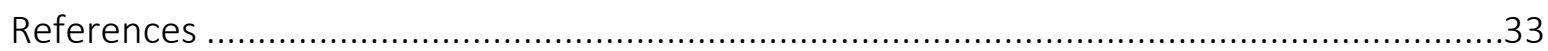




\section{|Chapter 3}

Incorporation of ${ }^{13} \mathrm{C}$ labelled glucose into soil microorganisms of grassland: Effects of fertilizer addition and plant functional group composition nfluence of fertilizer addition, cutting frequency and herbicide application on soil

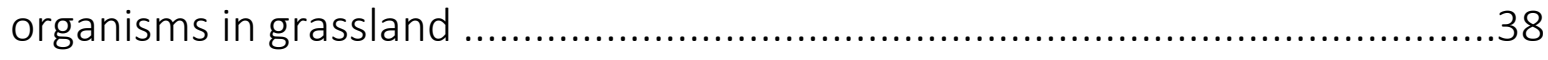

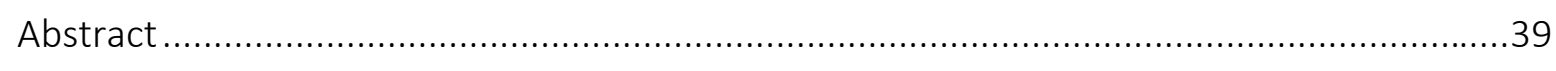

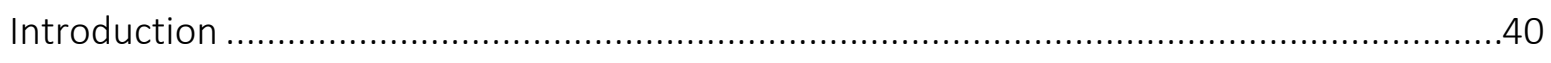

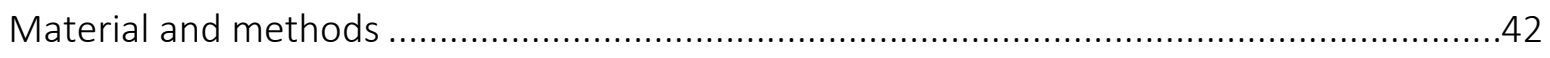

Study site and experimental design ........................................................................42

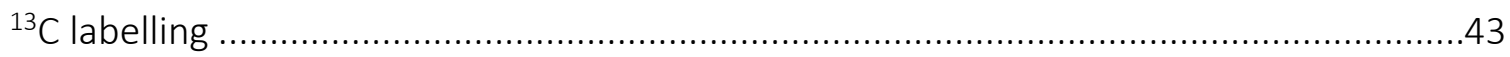

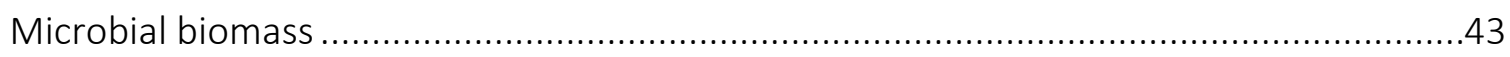

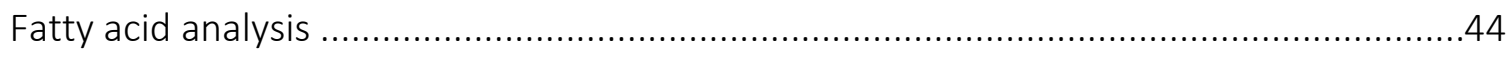

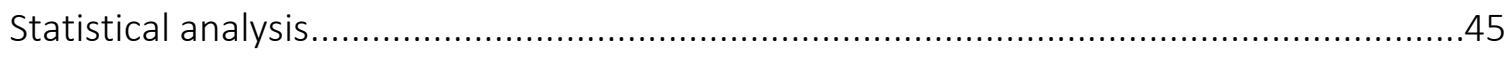

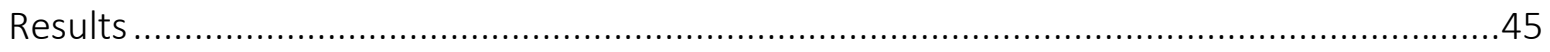

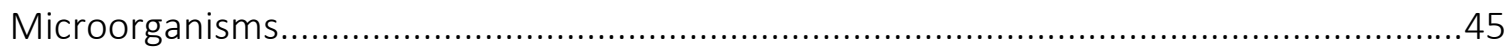

Incorporation of glucose C into microorganisms .........................................................

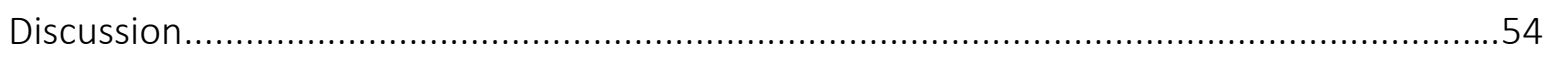

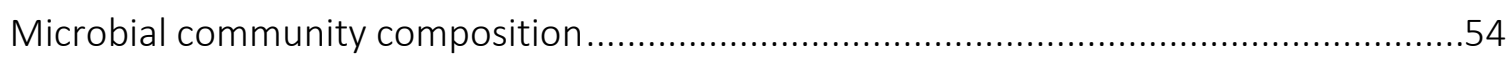

Microbial incorporation of glucose carbon …………………..................................5

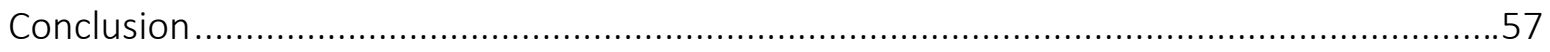

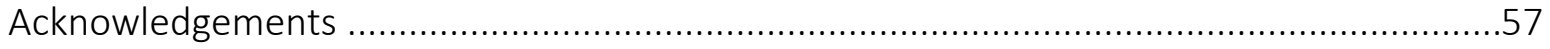

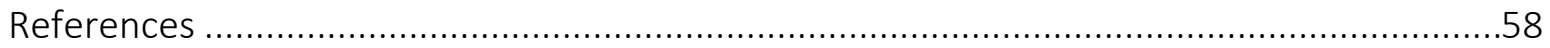

\section{|Chapter 4}

Fertilizer addition lessens the flux of microbial carbon to higher trophic levels in soil food webs of grasslandof fertilizer addition, cutting frequency and herbicide application on soil organisms in grassland............................................62

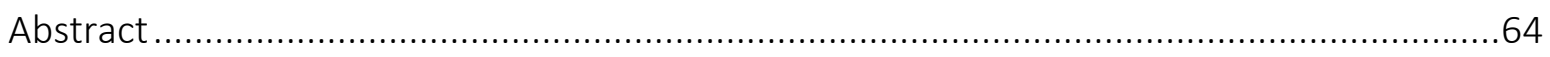

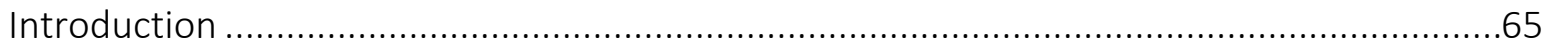

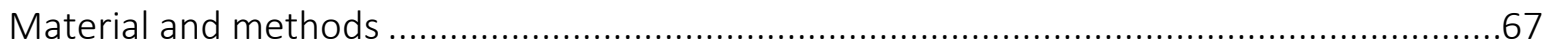

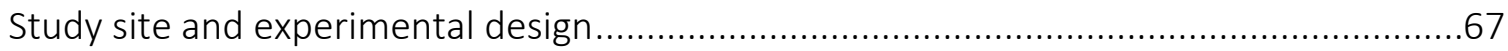

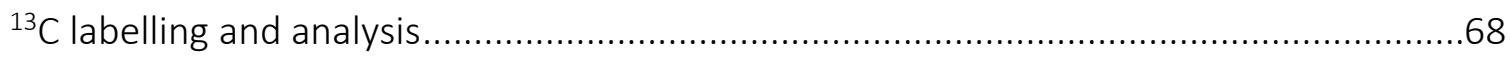

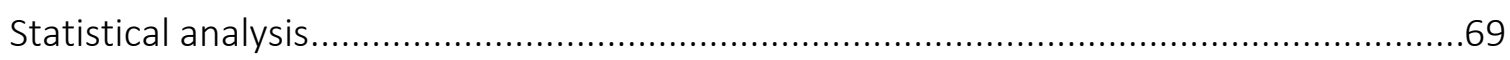

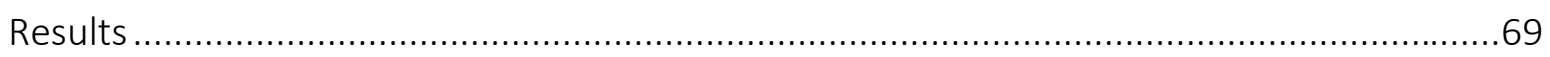




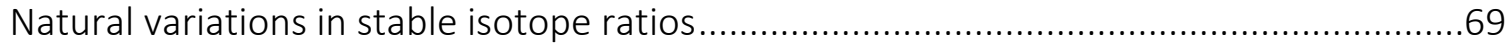

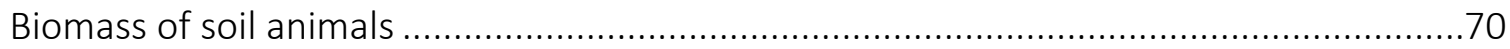

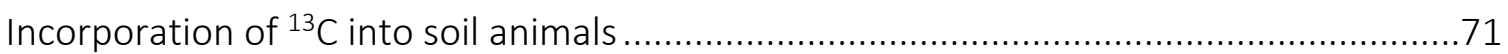

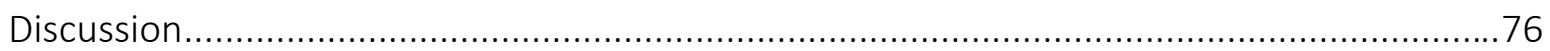

Variation in incorporation of glucose $\mathrm{C}$ between species ...............................................

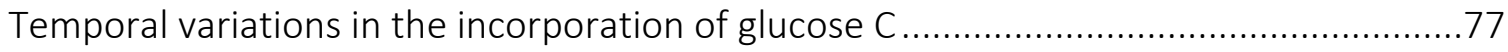

Variation in incorporation of glucose $\mathrm{C}$ with fertilizer addition and sward composition...78

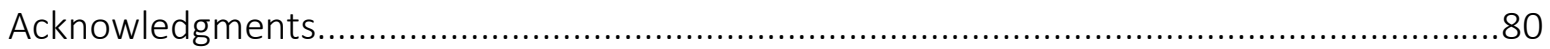

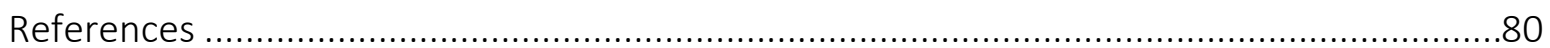

\section{|Chapter 5}

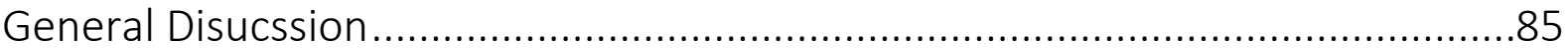

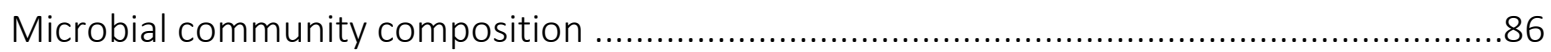

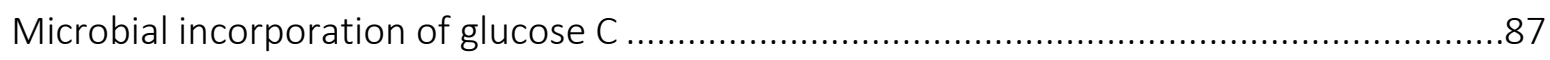

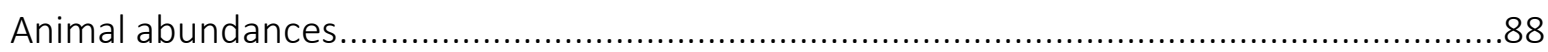

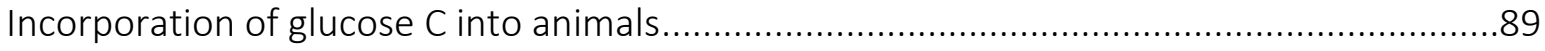

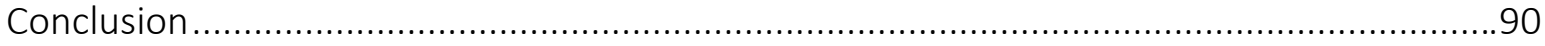

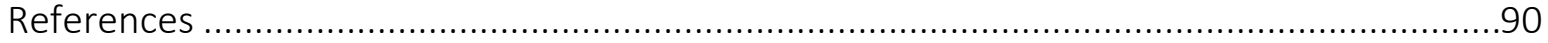

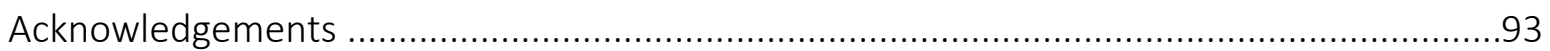

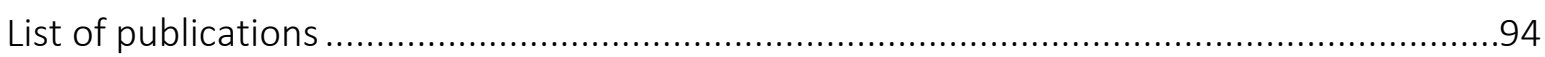

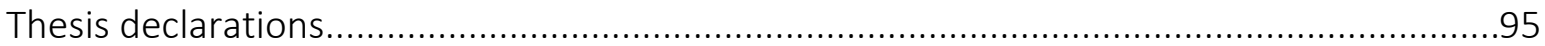




\section{Summary}

In Europe grasslands are among the most important agricultural systems. They are subject to continuous management intensification, which is potentially threatening ecosystem services. Since soil comprises the largest terrestrial carbon (C) pool, processes affecting $C$ sequestration are receiving increasing attention. Exploring the structure and functioning of food webs is crucial for improving the understanding of $\mathrm{C}$ fluxes within the soil system and how they react to anthropogenically induced land use changes. Despite growing attention, soil processes such as the flux of $\mathrm{C}$ from the aboveground to belowground food webs are still poorly understood.

I examined how agricultural management influences soil communities (including microorganisms and invertebrates), in particularly how it affects the flux of $C$ through the soil food web. The study was performed in the framework of the 'GRASSMANN' (Grassland Management) experiment, manipulating agricultural management practices including fertilizer addition (-NPK and +NPK), sward cutting frequency (one and three cuts per year) and sward composition by applying herbicide targeting either dicotyledons or monocotyledons in a temperate grassland.

In the study described in Chapter 2, the abundances of soil microorganisms and soil animals were recorded and evaluated. Microbial biomass $\left(C_{\text {mic }}\right)$ decreased in treatments cut once with fertilizer addition. However, in treatments cut thrice, $\mathrm{C}_{\text {mic }}$ did not decline with fertilizer addition, which suggests that cutting frequency lessens the detrimental effect of fertilizer input. Fungal but not bacterial PLFAs (phospholipid fatty acids) varied with sward composition, indicating fungi to respond more sensitively to changes in grassland management and sward composition as compared to bacteria. Abundances of dipterans and beetles increased with fertilizer addition but decreased with higher cutting frequency. Epigeic earthworms benefited from reduced proportion of monocotyledons. Overall, however, the results indicate that the majority of soil invertebrate taxa are rather insensitive to variations in grassland management practices. Consequently, the results indicate that microbial parameters are more sensitive to intensification of grassland management practices than soil animals, particularly in the shortterm after changes of management practices.

In order to identify root exudate associated trophic chains and their dynamics under different management regimes an in situ ${ }^{13} \mathrm{C}$ labelling experiment was performed by applying ${ }^{13} \mathrm{C}$ labelled 
glucose mimicking root exudates to each of the treatments except 'cutting frequency', aiming to trace the flux of $\mathrm{C}$ into microorganisms (Chapter 3) and soil animals (Chapter 4). As documented in the second study (Chapter 3), focusing on soil microorganisms, the fungal-tobacterial atom percent excess ratio of PLFAs was at a maximum early in the experiment, indicating that in relative terms fungi are initially more efficient in capturing low molecular weight $\mathrm{C}$ compounds entering the soil in pulses than bacteria, whilst in later stages of the experiment the opposite was true. These results challenge the established idea of a 'fast bacterial' and a 'slow fungal' channel. Furthermore, the incorporation of glucose $\mathrm{C}$ into fungi was most pronounced at the first two sampling dates, two and six weeks after glucose addition, and declined thereafter, whereas in bacteria it remained at a similar level for one year, suggesting that microbial residues are processed predominantly by bacteria, but not by fungi. In fertilized swards the fungal-to-bacterial ${ }^{13} \mathrm{C}$ ratio increased, while bacterial ${ }^{13} \mathrm{C}$ incorporation remained at the same level suggesting that NPK fertilizer addition increases the efficiency of resource capture by fungi. Sward composition generally had little effect on microbial community composition and glucose $\mathrm{C}$ incorporation.

Chapter 4 focuses on the incorporation of glucose $\mathrm{C}$ into soil animals, differentiating species into those feeding as primary decomposers on litter or living as herbivores by feeding on roots (not incorporating glucose $\mathrm{C}$ ), from those functioning as secondary decomposers feeding on microorganisms (incorporating glucose C). Each of the studied soil animal species incorporated glucose $\mathrm{C}$ indicating that the majority of grassland soil animal species relies on microorganisms as food resources, which themselves rely on root exudates. However, incorporation of glucose $C$ into soil animal species varied markedly with species identity, suggesting detritivorous microarthropods to complement each other in channelling microbial C through soil food webs. Fertilizer addition markedly reduced the concentration of glucose $\mathrm{C}$ in most soil animal species as well as the absolute transfer of glucose $\mathrm{C}$ into oribatid mites as major secondary decomposers. This suggests that fertilizer addition shifts the basis of the decomposer food web towards utilisation of unlabelled resources, presumably roots, i.e. towards a herbivore system, thereby lessening the link between microorganisms and microbial grazers and hampering the propagation of microbial $\mathrm{C}$ to higher trophic levels.

The results of this thesis advance the understanding of soil food web structure and their role in managed grassland for cycling of $\mathrm{C}$. They document the value of innovative techniques, 
especially stable isotope analysis using glucose as ${ }^{13} \mathrm{C}$ tracer, in advancing our understanding the functioning of soil food webs. The combination of stable isotope analysis, fatty acid analysis and compound specific ${ }^{13} \mathrm{C}$ analyses provide a powerful tool for studying the structure and the flux of $\mathrm{C}$ through the bacterial and fungal channel of grassland.

This thesis documented that grassland management markedly alters the structure of and carbon flux through soil food webs with the effects varying between management regimes and soil organisms. Overall, the results suggest that herbivore species benefit from higher biomass and nutritional status of plants due to fertilizer addition with some detritivorous species shifting to a more herbivorous diet. In contrast, microorganism and secondary decomposer relying on rhizodeposits are detrimentally affected. This suggests that grassland management practices and in particular fertilizer addition alter the interrelationship between the above- and belowground food web which needs closer consideration if we are to conserve the functionality of European grassland systems. 


\section{Chapter 1}

\section{General Introduction}

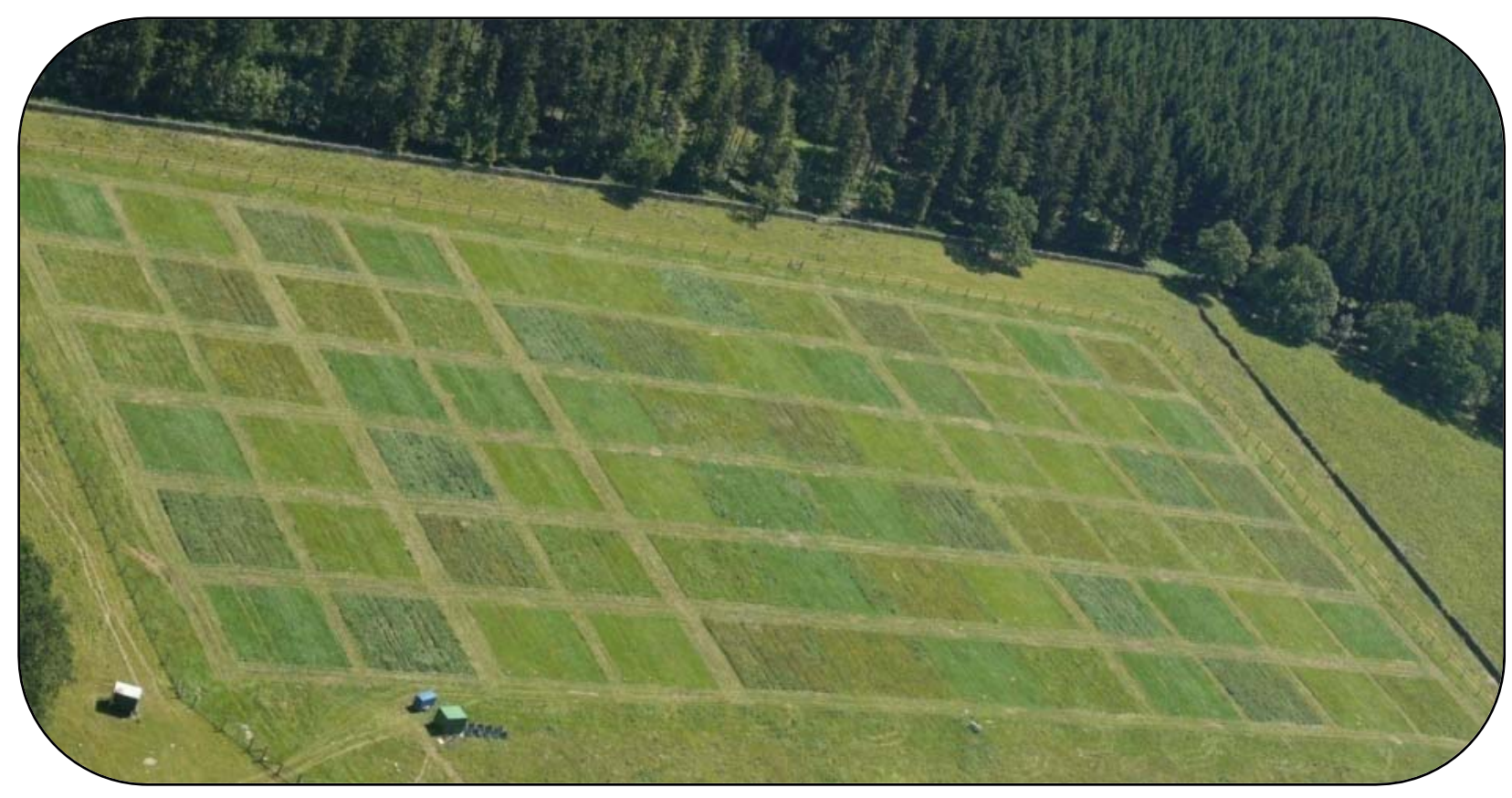

Photo by Laura Rose 


\section{The soil system}

Interest in soil processes such as decomposition and mineralisation is increasing, as these processes affect carbon (C) sequestration. The influence of anthropogenically induced land use change on C sequestration is of major concern (Post and Kwon 2000; Jastrow et al. 2007). Investigations on soil processes are particularly important as soil comprises the largest terrestrial C pool (Jones and Donnelly 2004).

Most $\mathrm{C}$ in belowground systems is bound in complex and recalcitrant compounds, such as lignin and humic acids, and hence not easily available for decomposers. Therefore, most soil microorganisms, as part of the base of food webs, are assumed to be limited predominantly by C (Demoling et al. 2007). A large portion of plant-derived C enters the belowground system via living roots, but the importance of these resources for belowground food webs has long been underestimated (Albers et al. 2006; Pollierer et al. 2007; Paterson et al. 2011). Roots mainly provide $\mathrm{C}$ in the form of exudates consisting of low molecular weight compounds, such as sugars, organic acids and amino acids, easily available to soil organisms (Bertin et al. 2003). The labile fraction of litter and roots is predominantly used by bacteria in contrast to fungi, which utilise more recalcitrant compounds of organic matter (Lundquist et al. 1999; Paterson et al. 2008). Most leaf litter compounds are rather recalcitrant (Bardgett et al. 2005; Berg and McClaugherty 2008) and therefore of minor importance as C source for the decomposer food web in forest systems in comparison of root derived C (Pollierer et al. 2007; Ruf et al. 2006). The importance of root exudates in managed grasslands may be even more pronounced as the aboveground biomass is removed as plant yield. Compartmentalisation into a fast (with $\mathrm{C}$ being cycled eight to ten times per year) and a slow (with C being cycled once every 10-100 years) channel have been suggested. Later these compartments have been ascribed to the bacterial and fungal energy channel, respectively (Coleman et al. 1983; Moore and Hunt 1988). Photosynthate $\mathrm{C}$ inputs via roots are affected by a number of natural and anthropogenic factors, such as nitrogen availability (Hodge et al. 1996), plant species composition (Grayston et al. 1998) and defoliation (Paterson et al. 2005), thereby affecting the way $C$ and nutrients are processed in belowground food webs.

Soil food webs typically comprise several trophic levels including primary decomposers, secondary decomposers and predators. Primary decomposers, such as diplopods, earthworms 
and some groups of oribatid mites, predominantly rely on plant litter and plant derived dead organic matter as food sources. Secondary decomposers, such as most oribatid mite species and collembolans, predominantly feed on microorganisms and microbial residues (Scheu and Falca 2000; Pollierer et al. 2009; Eissfeller et al. 2013). However, rather than occupying distinct trophic levels, species are forming a gradient from those predominantly feeding on litter to those predominantly feeding on microorganisms (Eissfeller et al. 2013; Scheu and Falca 2000). Predatory soil arthropods, such as mesostigmatic mites, centipedes, spiders, carabid and staphylinid beetles commonly are assumed to be food generalists (Scheu and Falca 2000; Scheu and Setälä 2002).

Despite the increasing interest in processes within soils, like the $\mathrm{C}$ flux from the above- into the belowground system, there still are large gaps of knowledge on the subject. The main reasons for this are the complex interactions within the soil food webs and the opaqueness of soil which prevents direct observations. Novel technologies such as stable isotope and fatty acid analysis allow indirect insights into energy fluxes within the belowground system. Natural variations in the ratio between stable isotopes of $\mathrm{C}\left({ }^{13} \mathrm{C} /{ }^{12} \mathrm{C}\right)$ and nitrogen $\left(\mathrm{N} ;{ }^{15} \mathrm{~N} /{ }^{14} \mathrm{~N}\right)$ have been shown to be a powerful tool for analysing the trophic structure of soil animal communities (Scheu and Falca 2000; Tiunov 2007). Furthermore, ${ }^{13} \mathrm{C}$ and ${ }^{15} \mathrm{~N}$ used as stable isotope tracers allow to follow $\mathrm{C}$ and $\mathrm{N}$ fluxes through belowground systems including soil microorganisms and invertebrate communities (Ostle et al. 2007; Pollierer et al. 2007; Strickland et al. 2012). For analysing soil microbial community structure, phospholipid fatty acid (PLFA) analysis is a commonly used method (Frostegård et al. 2011) and allows to reliably determine the relative biomass of bacteria and fungi in soil (Frostegård and Bååth 1996). Using ${ }^{13} \mathrm{C}$ as an isotope tracer, compound-specific stable isotope analysis of fatty acids (FAs), where ${ }^{13} \mathrm{C}$ signatures of individual FAs are measured, has the potential to trace the $\mathrm{C}$ flux into individual fungal or bacterial marker FAs. As glucose is a common component of root exudates (Hodge et al. 1996) it is often used as a model compound to track the incorporation of $\mathrm{C}$ in root exudates into belowground food webs (Evershed et al. 2006). 


\section{Grasslands}

In Europe grasslands are among the most important agricultural systems covering about $22 \%$ of the EU-25 land area (Stoate et al. 2009). Since the 1960s management of grasslands in Europe has been intensified continuously. Nitrogen $(N)$ fertilizer inputs led to increased aboveground plant biomass and resulted in earlier and more frequent cutting (Walker et al., 2004; LeBauer and Treseder 2008) whilst herbicide application reduced unwanted plants. These practices markedly enhanced grassland productivity (Isselstein et al. 2005).

The influence of management regimes including grasslands received increasing interest, as they affect major ecosystem services, such as $\mathrm{C}$ sequestration and storage of soil organic matter (Post and Kwon 2000; Jones and Donnelly 2004; Jastrow et al. 2007). Further, changes in land use are among the most important drivers for present and expected global decline in biodiversity (Vitousek et al. 1997; Sala et al. 2000). A variety of invertebrate taxa function as drivers for ecosystem services, such as low herbivore pest load, pollination and decomposition (Tscharntke et al. 2005; Isaacs et al. 2009).

However, increased plant productivity, due to $\mathrm{N}$ fertilization, is also associated with higher arthropod abundance in the aboveground system, in particular that of herbivore taxa (Siemann 1998; Haddad et al. 2000). In contrast, studies investigating the belowground system documented inconsistent responses of soil invertebrates to $\mathrm{N}$ fertilization with increases or decreases in abundances typically being limited to few taxa whereas most taxa showed no response (Bardgett and Cook 1998; Cole et al. 2005; 2008; Eisenhauer et al. 2013). In a metaanalysis Treseder (2008) found microbial biomass to decline by $15 \%$ on average under $\mathrm{N}$ fertilization. As $\mathrm{N}$ fertilization decreases the amount of $\mathrm{C}$ allocated into roots and into the rhizosphere (Johansson 1992; Bazot et al. 2006), and soil microorganisms are assumed to be limited predominantly by C (Daufresne and Loreau 2001; Demoling et al. 2007), microbial food resource declines and hence microbial biomass decreases. Consistent variations in the release of root $\mathrm{C}$ have been suggested to be responsible for changes in soil microbial biomass and $\mathrm{C}$ accumulation in experimental grassland systems (Eisenhauer et al. 2010).

Frequent cutting of grassland increased the mortality of aboveground invertebrates and stimulated emigration of the surviving mobile fauna (Thorbek and Bilde 2004; Humbert et al. 2012). But, cutting was also reported to increase microbial biomass, presumably due to 
stimulating root exudation (Mawdsley and Bardgett 1997; Guitian and Bardgett 2000), and this likely beneficially affected decomposers and thereby also higher trophic level invertebrates.

Further, herbicide applications reduce plant diversity at least in the short term (Virágh 1987). Increased numbers of plant species in grassland systems are associated with increased C sequestration in soil (Tilman et al. 2006; Fornara and Tilman 2008). However, the increase in C sequestration is unlikely due to plant diversity per se, it more likely results from changes in functional traits of one or more plant functional groups. For example, $\mathrm{N}$ fixing legumes play an important role in enhancing soil C and N storage (Fornara and Tilman 2008; De Deyn et al. 2009). Also, microbial biomass, and the abundance of collembolans and earthworms are increased in presence of legumes (Gastine et al. 2003; Salamon et al. 2004).

The scarce studies on grassland management practices on soil organisms and their inconsistent results call for further investigations. With this thesis I am aiming to elucidate the complex responds of below ground soil systems to management practices, i.e. fertilizer addition, cutting frequency and herbicide application targeting either dicotyledons or monocotyledons. Whereby, I investigated how agricultural management influences soil communities (including microorganisms and invertebrates) in general and how this management particularly affect the flux of $\mathrm{C}$ through the soil food web.

\section{Study site and experimental design}

The studies were carried out within the framework of the 'GRASSMAN' (Grassland Management) experiment, investigating consequences of grassland management intensity and sward composition for grassland functionality (Petersen et al. 2012). The study site is located in the Solling, a mountain range in northern Germany $\left(51^{\circ} 44^{\prime} \mathrm{N}, 9^{\circ} 23^{\prime} \mathrm{E} ; 490 \mathrm{~m}\right.$ a.s.I.). Mean annual temperature is $6.9^{\circ} \mathrm{C}$ and mean annual precipitation is $1028 \mathrm{~mm}$ (average of 1969-1990; German Weather Service). Prior to the experiment, the site was used for cattle grazing. Vegetation is classified as nutrient-poor montane mesic Lolio-Cynosuretum. The soil is characterized as Haplic Cambisol.

The experiment was set up in 2008 in a full factorial design comprising the factors sward composition (three levels differing in the proportion of monocotyledons and dicots), cutting 
frequency (one and three cuts per year) and fertilization (two levels). Each treatment level was replicated six times. For setting up the experiment, the site was mown and plots of a size of 15 x 15 m were established. Sward types of different plant composition were established in 2009 by applying herbicides targeting either dicotyledons or monocotyledons resulting in sward types reduced in dicotyledons (DR) or monocotyledons (MR); plots not treated with herbicides served as control (Ctr). In 2010 the proportion of plant functional groups were 78.0\%, 49.3\% and $65.7 \%$ for grasses, $21.8 \%, 48.7 \%$ and $32.8 \%$ for herbs, and $0.2 \%, 2.0 \%$ and $1.5 \%$ for legumes in DR, MR and Ctr treatments, respectively (T. From, unpubl. data). Fertilization treatments included NPK fertilizer addition (+NPK) and no fertilizer addition (-NPK). Fertilization started in 2008 with the addition of $\mathrm{N}$ and was continued in 2009 until 2012 by the addition of $\mathrm{N}$ split into two equal applications per year while the combined $\mathrm{P}$ and $\mathrm{K}$ fertilizer was applied once per year, resulting in an application of $180-30-100 \mathrm{~kg} \mathrm{~N}-\mathrm{P}-\mathrm{K} \mathrm{ha}{ }^{-1} \mathrm{y}^{-1}$ on respective plots and increased aboveground biomass production (Rose et al. 2012; Petersen et al. 2013). Half of the plots were mown annually once in July, the other half thrice in May, July and September.

\section{Objectives and chapter outline}

Focusing on the belowground food web of grassland in the framework of the GRASSMANexperiment, I aimed to investigate the effect of different management regimes (i.e. fertilizer addition, cutting frequency and sward composition) in temperate grassland on soil microorganisms and animals and particularly the flux of $\mathrm{C}$ within the belowground food web. Therefore, in the first study (Chapter 2), the abundance and community composition of soil microorganisms and soil animals as affected by management regime were evaluated. In the second part of the thesis an labelling experiment was performed applying ${ }^{13} \mathrm{C}$ labelled glucose, mimicking root exudates, aiming to trace the flux of $\mathrm{C}$ into microorganisms (Chapter 3 ) and soil animals (Chapter 4), identifying root exudate associated trophic chains.

In Chapter 2, the abundance of soil microorganisms and soil animals were recorded and evaluated. It was expected that management of grassland alters soil biota, with fertilizer addition and higher proportion of dicotyledons, especially legumes, resulting in an increase in microbial biomass and animal abundances as they benefit from higher and more nutritive food resources. A higher cutting frequency was expected to increase root exudation and therefore 
to be beneficial for microorganisms; on the contrary, animals were expected to be negatively affected due to disturbances. The results indicate a sensitively respond in microbial communities. In contrast soil invertebrate communities are rather insensitive to variations in grassland management practices.

Further an in situ labelling experiment was performed applying ${ }^{13} \mathrm{C}$ labelled glucose, simulating root exudates, to each of the treatments except 'cutting frequency', tracing the flux of $\mathrm{C}$ into soil organisms, identifying root exudate associated trophic chains and their dynamics under different management regimes over the period of one year. In Chapter 3 with the main focus on soil microorganisms, it was hypothesized that bacteria have a high and fast incorporation of glucose $\mathrm{C}$ but also to release the incorporated glucose $\mathrm{C}$ fast, as they rely on low molecular weight $\mathrm{C}$ compounds and have high turnover. In contrast, fungi were expected to have a slower incorporation with a more stable $\mathrm{C}$ pool, relying more on recalcitrant $\mathrm{C}$ sources. Contrary to our expectations in relative terms fungi had a faster and higher ${ }^{13} \mathrm{C}$ incorporation than bacteria, whereas bacteria had a more stable $\mathrm{C}$ pool over the period of the experiment.

Chapter 4 focuses on the incorporation of glucose $\mathrm{C}$ into soil animals, differentiating species feeding as primary decomposer on litter or living as herbivores by feeding on roots (not incorporating glucose C) from those functioning as secondary decomposers feeding on microorganisms (incorporating glucose C). It was expected that in fertilized treatments and swards increased in dicotyledons (especially legumes) the importance of direct feeding on plants and litter to outweigh the importance of microorganisms as food resource, as plants in those treatments have higher nutritional status. ${ }^{13} \mathrm{C}$ incorporation of glucose $\mathrm{C}$ into soil animal species varied markedly with species identity, suggesting detritivorous microarthropods to complement each other in channelling microbial C through soil food webs.

\section{References}

Albers D, Schaefer M, Scheu S (2006) Incorporation of plant carbon into the soil animal food web of an arable system. Ecology 87, 235-245.

Bardgett RD, Bowman WD, Kaufmann R, Schmidt SK (2005) A temporal approach to linking aboveground and belowground ecology. Trends in Ecology and Evolution 20, 634-41. 
Bardgett RD, Cook R (1998) Functional aspects of soil animal diversity in agricultural grasslands. Applied Soil Ecology 10, 263-276.

Bazot S, Ulff L, Blum H, Nguyen C, Robin C (2006) Effects of elevated $\mathrm{CO}_{2}$ concentration on rhizodeposition from Lolium perenne grown on soil exposed to 9 years of $\mathrm{CO}_{2}$ enrichment. Soil Biology and Biochemistry 38, 729-736.

Berg B, McClaugherty C (2008) Plant Litter: Decomposition, Humus Formation, Carbon Sequestration 2nd ed. Springer, Berlin.

Bertin C, Yang X, Weston LA (2003) The role of root exudates and allelochemicals in the rhizosphere. Plant and Soil 256, 67-83.

Cole L, Buckland SM, Bardgett RD (2005) Relating microarthropod community structure and diversity to soil fertility manipulations in temperate grassland. Soil Biology and Biochemistry 37, 1707-1717.

Cole L, Buckland SM, Bardgett RD (2008) Influence of disturbance and nitrogen addition on plant and soil animal diversity in grassland. Soil Biology and Biochemistry 40, 505-514.

Coleman DC, Reid CPP, Cole CV (1983) Biological strategies of nutrient cycling in soil systems. Advances in Ecological Research 13, 1-55.

Daufresne T, Loreau M (2001) Ecological stoichiometry, primary producer-decomposer interactions, and ecosystem persistence. Ecology 82, 3069-3082.

De Deyn GB, Quirk H, Yi Z, Oakley S, Ostle NJ, Bardgett RD (2009) Vegetation composition promotes carbon and nitrogen storage in model grassland communities of contrasting soil fertility. Journal of Ecology 97, 864-875.

Demoling F, Figueroa D, Bååth E (2007) Comparison of factors limiting bacterial growth in different soils. Soil Biology and Biochemistry 39, 2485-2495.

Eisenhauer N, Beßler H, Engels C, Gleixner G, Habekost M, Milcu A, Partsch S, Sabais ACW, Scherber C, Steinbeiss S, Weigelt A, Weisser WW, Scheu S (2010) Plant diversity effects on soil microorganisms support the singular hypothesis. Ecology 91, 485-496.

Eisenhauer N, Dobies T, Cesarz S, Hobbie SE, Meyer RJ, Worm K, Reich PB (2013) Plant diversity effects on soil food webs are stronger than those of elevated $\mathrm{CO}_{2}$ and $\mathrm{N}$ deposition in a long-term grassland experiment. Proceedings of the National Academy of Sciences 110, 6889-6894.

Eissfeller V, Beyer F, Valtanen K, Hertel D, Maraun M, Polle A, Scheu S (2013) Incorporation of plant carbon and microbial nitrogen into the rhizosphere food web of beech and ash. Soil Biology and Biochemistry 62, 76-81. 
Evershed RP, Crossman ZM, Bull ID, Mottram H, Dungait JAJ, Maxfield PJ, Brennand EL (2006) ${ }^{13} \mathrm{C}$-Labelling of lipids to investigate microbial communities in the environment. Current Opinion in Biotechnology 17, 72-82.

Fornara DA, Tilman D (2008) Plant functional composition influences rates of soil carbon and nitrogen accumulation. Journal of Ecology 96, 314-322.

Frostegård A, Bååth E (1996) The use of phospholipid fatty acid analysis to estimate bacterial and fungal biomass in soil. Biology and Fertility of Soils 22, 59-65.

Frostegård Å, Tunlid A, Bååth E (2011) Use and misuse of PLFA measurements in soils. Soil Biology and Biochemistry 43, 1621-1625.

Gastine A, Scherer-Lorenzen M, Leadley PW (2003) No consistent effects of plant diversity on root biomass, soil biota and soil abiotic conditions in temperate grassland communities. Applied Soil Ecology 24, 101-111.

Guitian R, Bardgett RD (2000) Plant and soil microbial responses to defoliation in temperate semi-natural grassland. Plant and Soil 220, 271-277.

Grayston SJ, Wang S, Campbell CD, Edwards AC (1998) Selective influence of plant species on microbial diversity in the rhizosphere. Soil Biology and Biochemistry 30, 369-378.

Haddad NM, Haarstad J, Tilman D (2000) The effects of long-term nitrogen loading on grassland insect communities. Oecologia 124, 73-84.

Hodge A, Grayston S, Ord B (1996) A novel method for characterisation and quantification of plant root exudates. Plant and Soil 184, 97-104.

Humbert J-Y, Ghazoul J, Richner N, Walter T (2012) Uncut grass refuges mitigate the impact of mechanical meadow harvesting on orthopterans. Biological Conservation 152, 96-101.

Isaacs R, Tuell J, Fiedler A, Gardiner M, Landis D (2009) Maximizing arthropod-mediated ecosystem services in agricultural landscapes: the role of native plants. Frontiers in Ecology and the Environment 7, 196-203.

Isselstein J, Jeangros B, Pavlu V (2005) Agronomic aspects of biodiversity targeted management of temperate grasslands in Europe - A review. Agronomy Research 3, 139-151.

Jastrow JD, Amonette JE, Bailey VL (2007) Mechanisms controlling soil carbon turnover and their potential application for enhancing carbon sequestration. Climate Change 80, 5-23.

Johansson G (1992) Below-ground carbon distribution in barley (Hordeum vulgare L.) with and without nitrogen fertilization. Plant and Soil 144, 93-99.

Jones MB, Donnelly A (2004) Carbon sequestration in temperate grassland ecosystems and the influence of management, climate and elevated $\mathrm{CO}_{2}$. New Phytologist 164, 423-439. 
LeBauer DS, Treseder KK (2008) Nitrogen limitation of net primary productivity in terrestrial ecosystems is globally distributed. Ecology 89, 371-379.

Lundquist EJ, Jackson LE, Scow KM, Hsu C (1999) Changes in microbial biomass and community composition, and soil carbon and nitrogen pools after incorporation of rye into three California agricultural soils. Soil Biology and Biochemistry 31, 221-236.

Mawdsley JL, Bardgett RD (1997) Continuous defoliation of perennial ryegrass (Lolium perenne) and white clover (Trifolium repens) and associated changes in the composition and activity of the microbial population of an upland grassland soil. Biology and Fertility of Soils 24, $52-58$.

Moore J, Hunt H (1988) Resource compartmentation and the stability of real ecosystems. Nature 333, 261-263.

Ostle N, Briones MJI, Ineson P, Cole L, Staddon P, Sleep D (2007) Isotopic detection of recent photosynthate carbon flow into grassland rhizosphere fauna. Soil Biology and Biochemistry 39, 768-777.

Paterson E, Osler G, Dawson LA, Gebbing T, Sim A, Ord B (2008) Labile and recalcitrant plant fractions are utilised by distinct microbial communities in soil: Independent of the presence of roots and mycorrhizal fungi. Soil Biology and Biochemistry 40, 1103-1113.

Paterson E, Sim A, Osborne SM, Murray PJ (2011) Long-term exclusion of plant-inputs to soil reduces the functional capacity of microbial communities to mineralise recalcitrant rootderived carbon sources. Soil Biology and Biochemistry 43, 1873-1880.

Paterson E, Thornton B, Midwood AJ, Sim A (2005) Defoliation alters the relative contributions of recent and non-recent assimilate to root exudation from Festuca rubra. Plant, Cell and Environment 28, 1525-1533.

Petersen U, Wrage N, Köhler L, Leuschner C, Isselstein J (2012) Manipulating the species composition of permanent grasslands-A new approach to biodiversity experiments. Basic and Applied Ecology 13, 1-9.

Petersen U, Wrage-Mönnig N, Isselstein J (2013) Effects of herbicide application to control sward composition in different management variants. International Journal of Biodiversity Science, Ecosystem Services and Management, 1-11.

Pollierer MM, Langel R, Körner C, Maraun M, Scheu S (2007) The underestimated importance of belowground carbon input for forest soil animal food webs. Ecology Letters 10, 729736.

Pollierer MM, Langel R, Scheu S, Maraun M (2009) Compartmentalization of the soil animal food web as indicated by dual analysis of stable isotope ratios $\left({ }^{15} \mathrm{~N} /{ }^{14} \mathrm{~N}\right.$ and $\left.{ }^{13} \mathrm{C} /{ }^{12} \mathrm{C}\right)$. Soil Biology and Biochemistry 41, 1221-1226. 
Post WM, Kwon KC (2000) Soil carbon sequestration and land-use change: processes and potential. Global Change Biology 6, 317-327.

Rose L, Coners H, Leuschner C (2012) Effects of fertilization and cutting frequency on the water balance of a temperate grassland. Ecohydrology 5, 64-72.

Ruf A, Kuzyakov Y, Lopatovskaya O (2006) Carbon fluxes in soil food webs of increasing complexity revealed by ${ }^{14} \mathrm{C}$ labelling and ${ }^{13} \mathrm{C}$ natural abundance. Soil Biology and Biochemistry 38, 2390-2400.

Sala O, Chapin F, Armesto J J, Berlow E, Bloomfield J, Dirzo R, Huber-Sanwald E, Huenneke LF, Jackson RB, Kinzig A, Leemans R, Lodge DM, Mooney HA, Oesterheld M, Poff NL, Sykes MT, Walker BH, Walker M, Wall DH (2000) Global biodiversity scenarios for the year 2100. Science 287:1770-1774.

Salamon J, Schaefer M, Alphei J, Schmid B, Scheu S (2004) Effects of plant diversity on Collembola in an experimental grassland ecosystem. Oikos 106, 51-60.

Scheu S, Falca M (2000) The soil food web of two beech forests (Fagus sy/vatica) of contrasting humus type: stable isotope analysis of a macro- and a mesofauna-dominated community. Oecologia 123, 285-296.

Scheu S, Setälä H (2002) Multitrophic interactions in decomposer food-webs, in: Tscharntke T., Hawkins B.A. (Eds.), Multitrophic Level Interactions. Cambridge University Press, Cambridge, pp. 223-264.

Siemann E (1998) Experimental tests of effects of plant productivity and diversity on grassland arthropod diversity. Ecology 79, 2057-2070.

Stoate C, Báldi A, Beja P, Boatman ND, Herzon I, van Doorn A, de Snoo GR, Rakosy L, Ramwell C (2009) Ecological impacts of early 21st century agricultural change in Europe - a review. Journal of Environmental Management 91, 22-46.

Strickland MS, Wickings K, Bradford MA (2012) The fate of glucose, a low molecular weight compound of root exudates, in the belowground foodweb of forests and pastures. Soil Biology and Biochemistry 49, 23-29.

Thorbek P, Bilde T (2004) Reduced numbers of generalist arthropod predators after crop management. Journal of Applied Ecology 41, 526-538.

Tilman D, Hill J, Lehman C (2006) Carbon-Negative Biofuels from Low-Input High-Diversity Grassland Biomass. Science 314, 1598-600.

Tiunov A (2007) Stable isotopes of carbon and nitrogen in soil ecological studies. Biology Bulletin 34, 395-407. 
Treseder KK (2008) Nitrogen additions and microbial biomass: a meta-analysis of ecosystem studies. Ecology Letters 11, 1111-20.

Tscharntke T, Klein AM, Kruess A, Steffan-Dewenter I, Thies C (2005) Landscape perspectives on agricultural intensification and biodiversity - ecosystem service management. Ecology Letters 8, 857-874.

Virágh K (1987) The effect of herbicides on vegetation dynamics: A five year study of temporal variation of species composition in permanent grassland plots. Folia Geobotanica 22, 385403.

Vitousek PM, Mooney HA, Lubchenco J, Melillo JM (1997) Human domination of Earth's ecosystems. Science $277,494-499$.

Walker KJ, Stevens PA, Stevens DP, Mountford JO, Manchester SJ, Pywell RF (2004) The restoration and re-creation of species-rich lowland grassland on land formerly managed for intensive agriculture in the UK. Biological Conservation 119, 1-18. 


\title{
Chapter 2
}

\section{Influence of fertilizer addition, cutting frequency and herbicide application on soil organisms in grassland}

\author{
Kathleen Lemanski \& Stefan Scheu
}
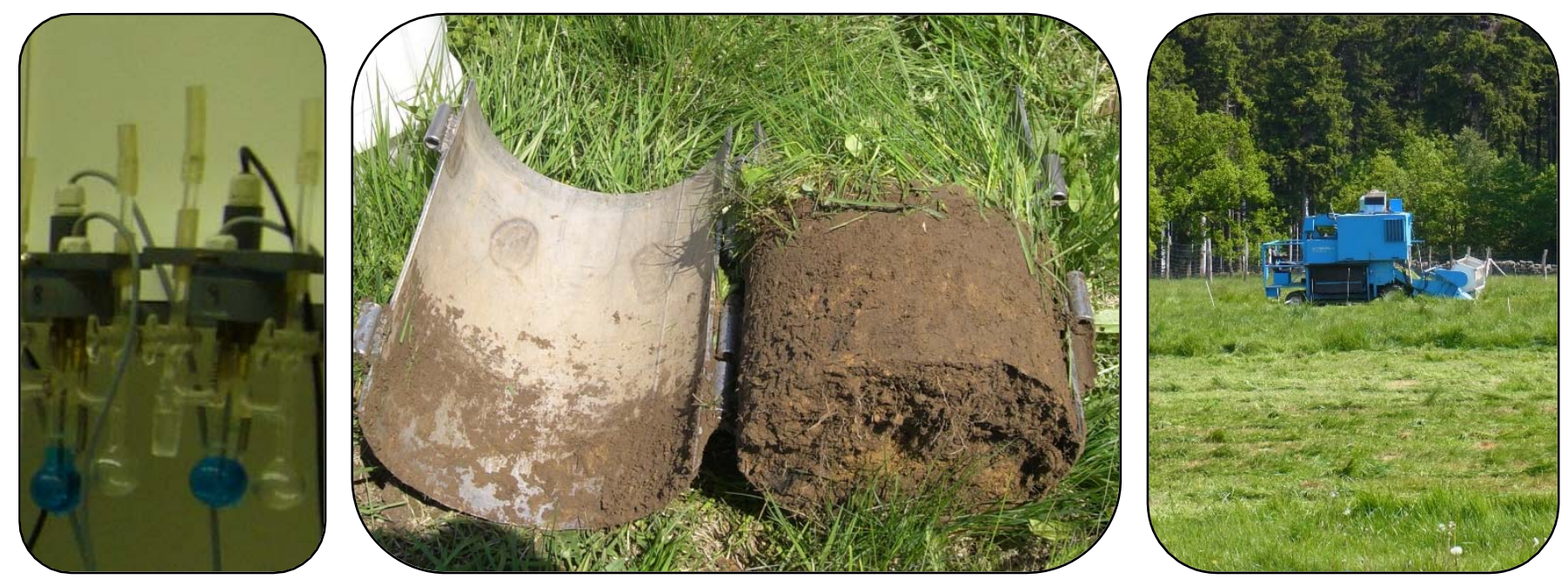

Lemanski K, Scheu S. Influence of fertilizer addition, cutting frequency and herbicide application on soil organisms in grassland. Biology and Fertility of Soils. 


\section{Abstract}

In Europe grasslands are among the most important agricultural systems which are subject to continuous management intensification, potentially threatening ecosystem services. We analysed the impact of management of permanent grassland, i.e. fertilizer addition (-NPK and +NPK), cutting frequency (one and three cuts per year) and herbicide application targeting either dicotyledons or monocotyledons, on microorganisms and soil animals. Microbial biomass decreased in treatments cut once with fertilizer addition. However, in treatments cut thrice microbial biomass did not decline with fertilizer addition, suggesting that cutting frequency alleviates the detrimental effect of fertilizer input. Fungal but not bacterial phospholipid fatty acid biomarkers varied with sward composition, indicating fungi more sensitively respond to changes in grassland management and sward composition than bacteria. The abundance of dipterans and beetles increased with fertilizer addition but decreased with sward cutting frequency. Epigeic earthworms benefited from reduced proportion of monocotyledons. The results indicate that microbial parameters more sensitively respond to intensification of management practices in grassland than soil animals, in particular early after changes of management practices.

\section{Keywords}

Soil microflora; soil fauna; fertilizer; plant functional groups; cutting frequency; PLFA 


\section{Introduction}

In Europe grasslands are among the most important agricultural systems covering about $22 \%$ of the EU-25 (European Union, with 25 member states, 2004-2006) land area (Stoate et al. 2009). Since the 1960s management of grasslands in Europe has been intensified continuously, enhancing productivity (Isselstein et al. 2005). Nitrogen (N) fertilizer is applied to increase aboveground plant biomass and swards are cut earlier and more frequently (Walker et al. 2004; LeBauer and Treseder 2008). Further, herbicide applications reduced unwanted plants. At the same time, changes in land use are among the most important drivers for present and expected global decline in biodiversity (Virágh 1987; Vitousek et al. 1997; Sala et al. 2000) and ecosystem functioning (Suding et al. 2005; Harpole and Tilman 2007). A variety of groups of invertebrates function as drivers of ecosystem services, such as low herbivore pest load, pollination and decomposition (Tscharntke et al. 2005; Isaacs et al. 2009). However, beside negative effects on diversity increased plant productivity is associated by higher arthropod abundance in aboveground system (Siemann 1998; Haddad et al. 2000). Similarly, in the belowground system microarthropod abundance and biomass has been found to increase with $\mathrm{N}$ fertilization, presumably, due to increased plant biomass and associated increased microbial biomass acting as resource for soil decomposer animals (Cole et al. 2005; van der Wal et al. 2009). In contrast, $\mathrm{N}$ fertilization decreases the amount of carbon (C) allocated by plants into roots and via root exudates into the rhizosphere (Marschner et al. 1996; Bazot et al. 2006). Variations in the release of root $\mathrm{C}$ are likely to be responsible for changes in soil microbial biomass in grassland systems of different diversity (Eisenhauer et al. 2010), but effects of nitrogen addition on microorganisms remain little understood (Treseder 2008).

Frequent cutting of grassland increases the mortality of aboveground invertebrates and stimulates emigration of the surviving mobile fauna (Thorbek and Bilde 2004; Humbert et al. 2012). On the other hand, cutting increases microbial biomass, presumably due to stimulating root exudation (Mawdsley and Bardgett 1997; Guitian and Bardgett 2000), and this likely beneficially affects decomposers and thereby also higher trophic level invertebrates.

Increased plant species number in $\mathrm{N}$ limited grassland systems is associated by increased $\mathrm{C}$ sequestration in soil (Tilman et al. 2006). However, the increase in C sequestration is unlikely due to plant diversity per se, rather, it likely results from changes in functional traits of one or more plant functional groups. For example, $\mathrm{N}$ fixing legumes play an important role in 
enhancing soil C and N storage (Fornara and Tilman 2008; De Deyn et al. 2009). Also, microbial biomass, and the abundance of collembolans (Collembola) and earthworms (Lumbricidae) are increased in presence of legumes (Gastine et al. 2003; Salamon et al. 2004). However, soil microorganisms also have been found to respond little to changes in plant functional group composition (Marshall et al. 2011), but rather to changes in plant diversity (Eisenhauer et al. 2013) and fungal communities have been shown to vary with grass species identity (Mouhamadou et al. 2013).

The scarce studies on effects of grassland management practices on soil organisms and their inconsistent results call for further investigations. Therefore, we studied variations in community structure of soil microorganisms and animals in a temperate grassland system as affected by NPK fertilizer addition, cutting frequency and sward composition, i.e. variations in plant functional groups. We hypothesized that (1) fertilizer addition increases, (2) more frequent cutting decreases, and (3) herbicide-induced increase in the abundance of dicotyledons increases the abundance of soil biota. We expected the beneficial impact of fertilizer addition to be due to increased resource availability, i.e. increased plant productivity, the negative effect of frequent cutting to be due to disturbances overriding beneficial effects of increased root exudation, and the positive effect of higher frequency of dicotyledons to be due in particular to increased abundance of legumes.

\section{Material and methods}

\section{Study site and experimental design}

The experiment was carried out within the framework of the 'GRASSMAN' (Grassland Management) experiment investigating effects of grassland management on ecosystem functioning (Petersen et al. 2012). The study site is located in the Solling, a small mountain range in the north of Germany $\left(51^{\circ} 44^{\prime} \mathrm{N}, 9^{\circ} 23^{\prime} \mathrm{E} ; 490 \mathrm{~m}\right.$ a.s.I.). Mean annual temperature is $6.9^{\circ} \mathrm{C}$ and mean annual precipitation is $1028 \mathrm{~mm}$ (average of 1969-1990; German Weather Service). Until two years before the start of the experiment the grassland had been used for cattle grazing and received $80 \mathrm{~kg} \mathrm{~N} \mathrm{ha}^{-1} \mathrm{y}^{-1}$. Vegetation is classified as nutrient poor montane mesic Lolio-Cynosuretum and the soil is characterized as Haplic Cambisol. 
The experiment was set up in 2008 in a full factorial design comprising the factors sward composition (three levels differing in the proportion of plant functional groups), cutting frequency (one and three cuts per year) and fertilization (with and without fertilizer addition). Each treatment level was replicated six times. For setting up the experiment the site was mown and plots of a size of $15 \times 15$ m were established. Sward compositions were manipulated by applying herbicides targeting either dicotyledons or monocotyledons, resulting in sward composition reduced in dicotyledons (DR) or monocotyledons (MR); plots not treated with herbicides served as control (Ctr). In 2010 the DR sward comprised 78.0\%, 21.8\% and $0.2 \%$, the MR sward $49.3 \%, 48.7 \%$ and $2.0 \%$ and the Ctr sward $65.7 \%, 32.8 \%$ and $1.5 \%$ of grasses, herbs and legumes, respectively. (T. From. unpubl. data). Fertilization treatments included NPK fertilizer addition (+NPK) and no fertilizer addition (-NPK). Fertilization started in 2008 with the addition of $\mathrm{N}$ and was continued in 2009 by the addition of $\mathrm{N}$, which was split into two equal applications per year, while the combined $\mathrm{P}$ and $\mathrm{K}$ fertilizer was applied once per year, resulting in the application of 180-30-100 kg N-P-K ha-1 $\mathrm{y}^{-1}$ on respective plots. Half of the plots were mown annually once in July, the other half thrice in May, July and September.

\section{Microbial biomass}

In May 2010 three soil cores $(5 \mathrm{~cm} \varnothing)$ per plot were taken, mixed and sieved to determinate soil microbial biomass $\left(\mathrm{C}_{\text {mic }}\right)$ and phospholipid fatty acids (PLFA). $\mathrm{C}_{\text {mic }}$, basal respiration and specific respiration were determined using SIR (substrate-induced respiration), i.e., the respiratory response of microorganisms to glucose addition (Anderson and Domsch 1978). Respiration rates were measured using an automated $\mathrm{O}_{2}$ microcompensation system (Scheu 1992). Soil basal respiration $\left(\mu \mathrm{O}_{2} \mathrm{~g}^{-1}\right.$ soil dry $w \mathrm{~h} \mathrm{~h}^{-1}$ ) was calculated as mean of $\mathrm{O}_{2}$ consumption rates between 14 and $22 \mathrm{~h}$ (without addition of substrate) after attachment of the vessels to the measurement system. Subsequently, samples were supplemented with $6 \mathrm{mg}$ glucose $\mathrm{g}^{-1}$ soil dry wt (Beck et al. 1993) and the mean of the three lowest values within 2-10 h after addition of glucose was taken as maximum initial respiratory response (MIRR). $C_{\text {mic }}\left(\mu g \mathrm{C} \mathrm{g}^{-1}\right.$ soil dry wt) was calculated as 38 x MIRR (Beck et al. 1997). From basal respiration and microbial biomass microbial specific respiration $\left(\mu \mathrm{O}_{2} \mathrm{mg}^{-1} \mathrm{C}_{\text {mic }} \mathrm{h}^{-1}\right)$ was calculated. 
Fatty acid analysis

From the six replicates four were selected at random for fatty acid (FA) analysis. PLFAs were extracted following Frostegård et al. (1991) and analysed by gas chromatography using Clarus 500 (Perkin Elmer, Waltham, USA). PLFAs a15:0, i15:0, i16:0 and i17:0 were used as marker FAs for gram positive bacteria, cy17:0 and cy19:0 as marker FAs for gram negative bacteria, $18: 2 \omega 6,9$ as saprotrophic fungal marker and $16: 1 \omega 7$ as unspecific bacterial marker (Ruess and Chamberlain 2010).

\section{Invertebrate animal abundance}

In May 2010 one small $(5 \mathrm{~cm} \varnothing)$ and one large soil core $(20 \mathrm{~cm} \varnothing)$ per plot were taken for extracting soil meso- and macrofauna, respectively. Samples were divided into sward, hereinafter termed litter layer, and $0-3 \mathrm{~cm}$ soil layer, and extracted using a modified heat extractor (Kempson et al. 1963). Invertebrates were filtered into collection vials and stored in $70 \%$ ethanol until determination and counting.

\section{Statistical analysis}

The effect of fertilizer addition, sward composition and cutting frequency on $\mathrm{C}_{\text {mic, }}$ basal respiration, specific respiration, ratios of FAs (fungal-to-bacterial PLFA ratio and gram negativeto-gram positive PLFA ratio) and total bacterial and fungal PLFA were analysed by individual ANOVAs. Animal taxa were analysed using General Linear Model (GLM) accounting for missing values. Earthworms and collembolans were first analysed by MANOVA and individual taxonomic groups with (protected) ANOVAs. Analyses were performed using SAS 9.2 (SAS Institute, Cary, NC, USA) Principal components analysis (PCA) was performed using CANOCO for Windows 5 (Microcomputer Power, Ithaca, NY, USA) (ter Braak and Šmilauer 2012), with experimental treatments included as supplementary variables. Prior to the analyses the data were inspected for homogeneity of variance using Levene test; log-transformation generally improved homogeneity of variance and therefore we uniformly used log-transformed data for statistical analyses. Means given in text and tables are based on non-transformed data. 


\section{Results}

\section{Microorganisms}

$\mathrm{C}_{\text {mic }}$ was on average 922 ( $\left.\pm 188 \mathrm{SD}\right) \mu \mathrm{g} \mathrm{C} \mathrm{g}{ }^{-1}$ dry wt but significantly varied with fertilizer addition and cutting frequency. Fertilized treatments cut once per year had lower $\mathrm{C}_{\text {mic }}$, whereas this was not the case if swards were cut thrice (Table 1; Fig. 1). Neither basal respiration nor microbial specific respiration varied significantly between treatments (Table 1 and 2).

Fungal PLFA in MR sward significantly exceeded that in DR and Ctr sward. Similarly, the fungalto-bacterial PLFA ratio in MR sward significantly exceeded that in DR and Ctr (Table 1 and 2). Neither bacterial PLFAs nor gram negative-to-gram positive PLFA ratio significantly varied between treatments (Table 1 and 2).

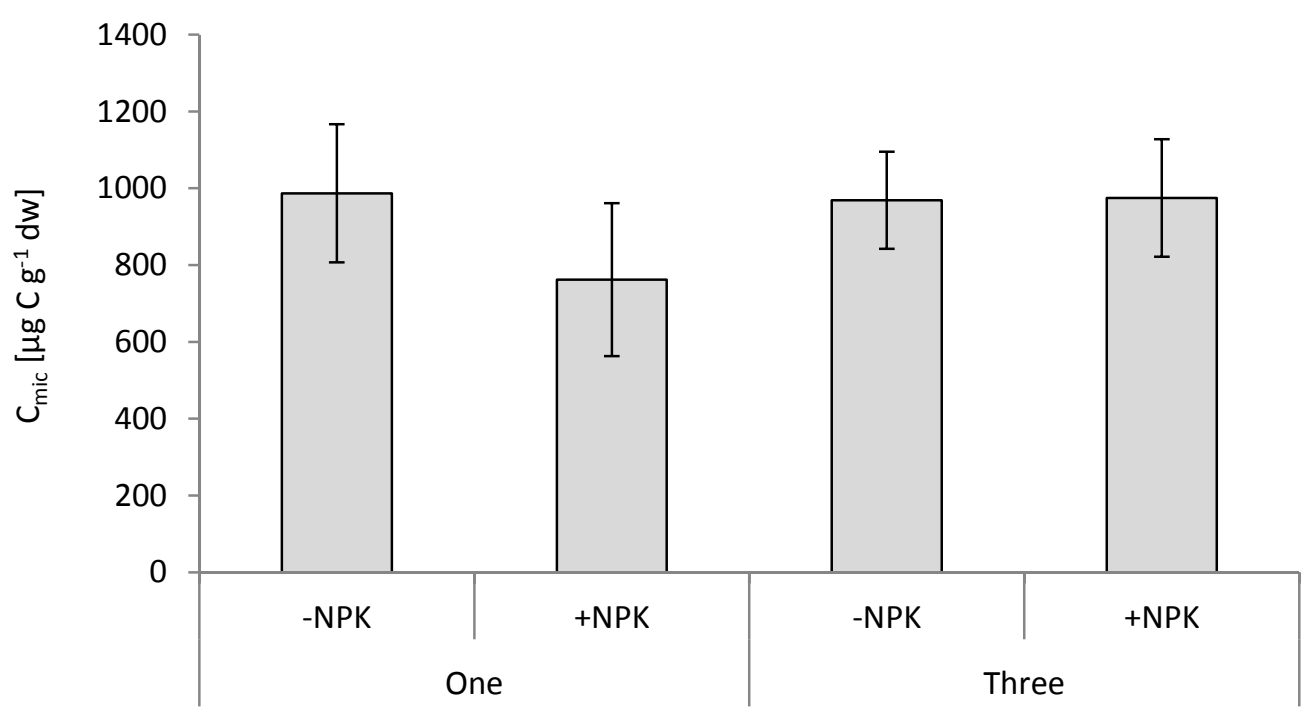

Figure 1 Effect of the addition of fertilizer and cutting frequency on soil microbial biomass $\left(C_{\text {mic }}\right)$; means with standard deviation; for statistical analyses see Table 1. 
Table 1 GLM table of F- and P-values on the effect of fertilizer addition, sward composition and cutting frequency on microbial biomass ( $C_{\text {mic }}$ ), basal respiration (BR), microbial specific respiration (Mic SR), bacterial and fungal PLFAs, fungal-to-bacterial and Gram negative-to-Gram positive PLFA ratio. Significant effects are given in bold. None of the interactions were significant (not shown).

\begin{tabular}{|c|c|c|c|c|c|c|c|c|c|c|}
\hline & \multicolumn{2}{|c|}{ Block } & \multicolumn{2}{|c|}{ Fertilizer } & \multicolumn{2}{|c|}{ Sward } & \multicolumn{2}{|c|}{ Cut } & \multicolumn{2}{|c|}{ Fertilizer $\times$ Cut } \\
\hline & $F$ & $P$ & $\mathrm{~F}$ & $P$ & $\mathrm{~F}$ & $P$ & $F$ & $P$ & $\mathrm{~F}$ & $P$ \\
\hline $\mathrm{C}_{\text {mic }}$ & 0.67 & 0.649 & 7.31 & 0.009 & 0.34 & 0.711 & 6.78 & 0.012 & 7.21 & 0.010 \\
\hline BR & 0.75 & 0.593 & 2.55 & 0.116 & 0.96 & 0.389 & 2.30 & 0.135 & 3.04 & 0.087 \\
\hline Bacterial PLFAs & 17.55 & $<0.0001$ & 2.66 & 0.113 & 0.63 & 0.542 & 2.61 & 0.117 & 1.10 & 0.302 \\
\hline Fungal PLFA & 9.62 & 0.000 & 0.87 & 0.359 & 6.01 & 0.006 & 0.40 & 0.534 & 2.04 & 0.163 \\
\hline Fungal-to-bacterial PLFA ratio & 3.88 & 0.019 & 2.29 & 0.141 & 6.52 & 0.004 & 0.03 & 0.854 & 1.08 & 0.306 \\
\hline
\end{tabular}




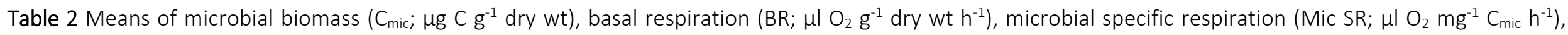
bacterial and fungal PLFAs ( $\mathrm{nmol} \mathrm{g} \mathrm{g}^{-1} \mathrm{dry}$ wt), fungal-to-bacterial and Gram negative-to-Gram positive PLFA ratio affected by fertilizer addition, sward composition and cutting frequency. Significant effects are given in bold.

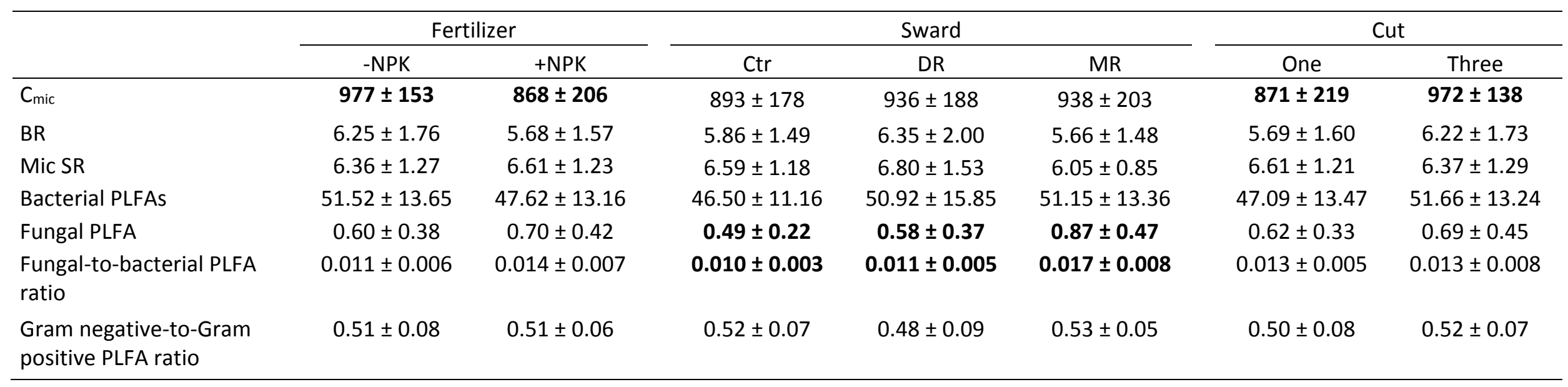




\section{Detritivorous animals}

The total abundance (including soil and litter layer and hereafter just named abundance) of epigeic earthworms varied with sward composition and was higher in MR than in DR swards, with the Ctr being intermediate (Table 3 and 4). The abundance of dipterans (Diptera) was significantly higher in fertilized as compared to non-fertilized treatments (Table 3 and 4; Fig. 2a). Further, the abundance of dipterans in treatments cut once per year exceeded that in treatments cut thrice per year with the difference being more pronounced in DR as compared to Ctr and MR sward (interaction between sward composition and cutting frequency; Table 3). The abundance of oribatid mites (Oribatida) in trend was higher in non-fertilized as compared to fertilized treatments (Table 3 and 4 ; Fig. 2b). Collembolans mainly comprised Isotomidae (42 $\pm 24 \%)$ and Onychiuridae (31 $\pm 25 \%)$ but also Symphypleona (14 $\pm 16 \%)$, Entomobryidae $(9 \pm$ $13 \%)$, and Hypogastruridae and Neanuridae (together $3 \pm 4 \%$ ). Neither the abundance of total collembolans nor that of individual collembolan groups, with exception for the Entomobryidae, was significantly affected by experimental treatments but varied markedly between blocks (Table 1). Entomobryidae reached higher abundance in non-fertilized treatments, with 2693 $( \pm 2596)$ ind. $\mathrm{m}^{-2}$ in comparison to 1527 ( \pm 1936$)$ ind. $\mathrm{m}^{-2}$ in fertilized treatments (ANOVA, $F_{1,45}$ $=5.24, P=0.027)$.

\section{Predatory animals}

The majority of beetles (Coleoptera) were larvae (73 $\pm 12 \%)$ and comprised mainly predatory taxa including Staphylinidae (78 $\pm 19 \%)$, Cantharidae $(10 \pm 17 \%)$, Elateridae $(7 \pm 8 \%)$ and Carabidae $(4 \pm 6 \%)$. Adult beetles also comprised mainly predators such as Staphylinidae (83 \pm $17 \%)$ and Carabidae $(8 \pm 12 \%)$, but also herbivores such as Curculionidae (5 $\pm 9 \%)$ and Nitidulidae $(4 \pm 10 \%)$. The abundance of beetles in treatments with fertilizer addition and only one cut per year exceeded that in treatments without fertilizer addition cut thrice (significant interaction between fertilizer addition and cutting frequency; Table 3).

Spiders (Aranea) comprised mainly Linyphiidae (96 $\pm 7 \%)$ and some Lycosidae $(3 \pm 6 \%)$ and Tetragnathidae ( $1 \pm 4 \%)$. For centipedes (Chilopoda) the interaction between fertilizer, sward and cutting frequency was significant (Table 3). In fertilized treatments centipede abundance increased in the order MR $<\mathrm{DR}<\mathrm{Ctr}$, with abundances being generally lower in treatments cut 
once per year. In fertilized treatments the MR sward cut once had the lowest abundance with $16( \pm 17)$ ind. $\mathrm{m}^{-2}$ and the Ctr sward cut thrice per year the highest abundance with $57( \pm 93)$ ind. $\mathrm{m}^{-2}$. In non-fertilized treatments abundances increased in swards cut once per year in the order $\mathrm{DR}<\mathrm{Ctr}<\mathrm{MR}$, whereas abundances declined in this order in treatments cut thrice per year. In treatments cut thrice this effect was more pronounced, reaching a maximal abundance of 118 ( \pm 86 ) ind. $\mathrm{m}^{-2}$ in the DR sward and a minimum of zero in the MR sward. However, because of the low number of individuals interpreting these differences remains ambiguous.

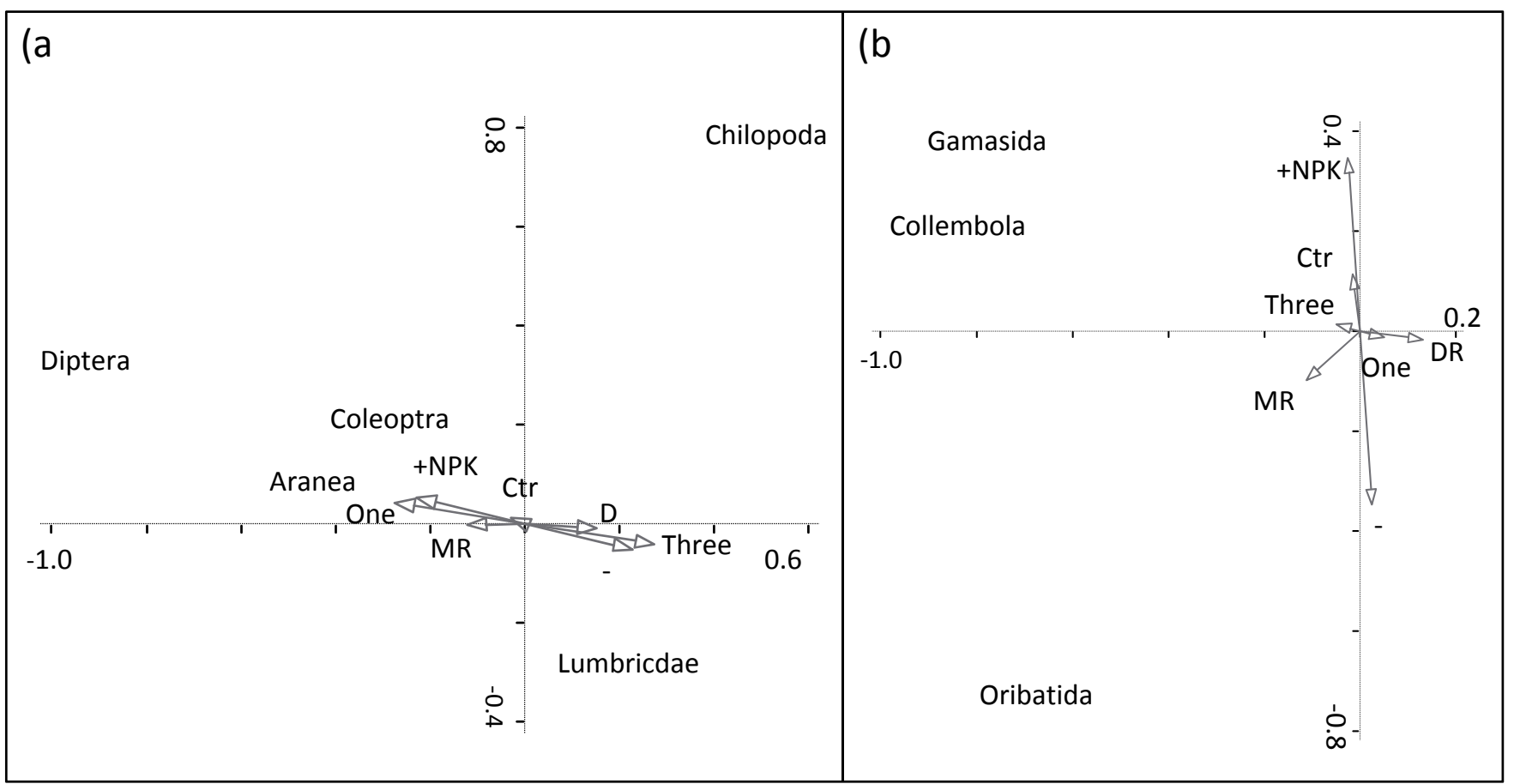

Figure 2 Principal components analysis (PCA) with experimental treatments included as supplementary variables for the soil (a) macrofauna and (b) mesofauna; eigenvalues of the first and second axis of 0.477 and 0.209 (a) and of 0.625 and $0.220(b)$, respectively. 
Table 3 GLM and MANOVA (for total Lumbricidae and Collembola) table of F- and P- values on the effect of fertilizer addition, sward composition and cutting frequency on the abundance (in soil and litter) of animal taxa. Significant effects are given in bold.

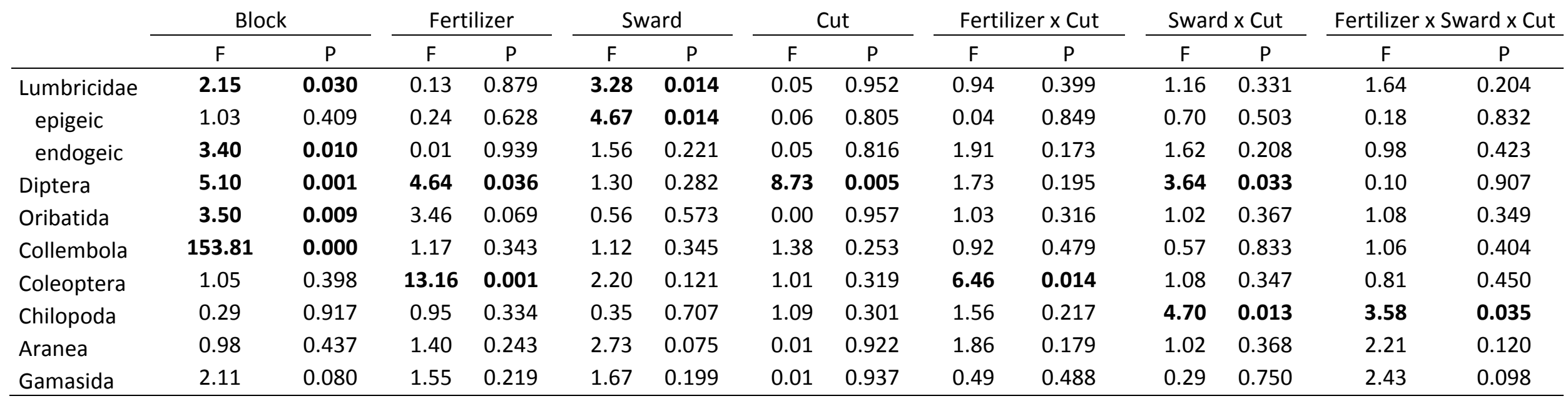


Table 4 Mean abundance (in soil and litter) and standard deviation (ind. $\mathrm{m}^{-2}$ ) of taxa as affected by fertilizer addition, sward composition and cutting frequency. Significant effects are given in bold.

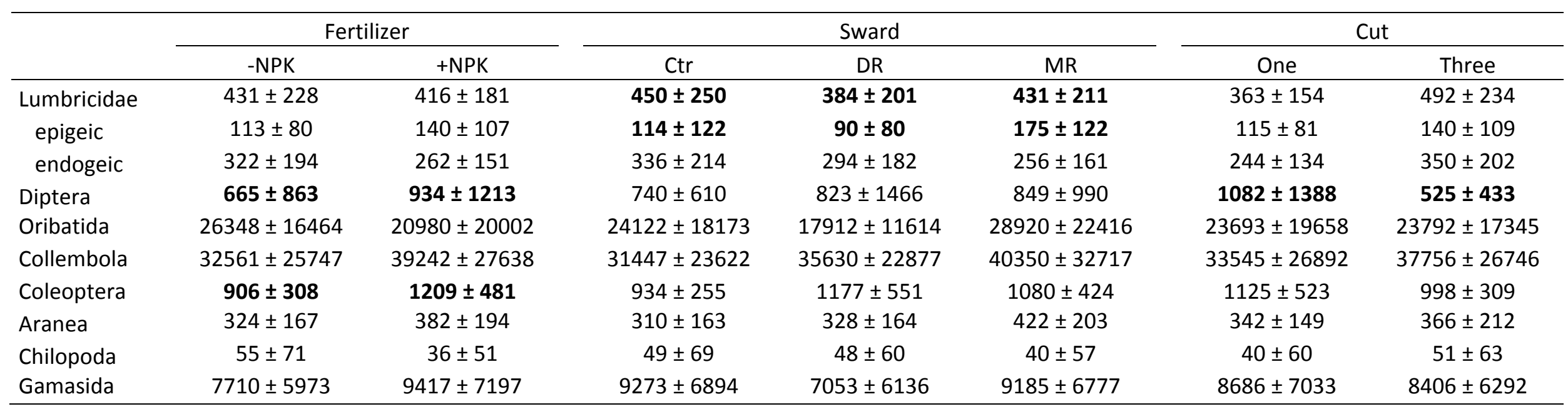




\section{Depth distribution}

The majority of animal taxa were more abundant in the litter than in the soil layer. Only in centipedes the abundance in soil (58 $\pm 45 \%)$ exceeded that in litter. Generally, the percentage of animals in the litter layer decreased in the following order oribatid mites $\geq$ spiders $>$ beetles $>$ dipterans > gamasid mites (Gamasida) > earthworms > collembolans > centipedes (Fig. 3).

Dipterans predominantly occurred in the litter layer and this was most pronounced in treatments cut thrice $\left(F_{1,50}=4.88, P=0.032\right)$. Oribatid mites also mainly occurred in the litter layer but this was more pronounced in non-fertilized treatments $\left(F_{1,48}=5.99, P=0.018\right)$. The percentage of beetle larvae in the litter layer of swards cut once increased in the order MR > Ctr $>D R$, whereas in treatments cut thrice it declined in this order $\left(F_{2,51}=4.52, P=0.016\right.$ for the interaction between sward composition and cutting frequency, data not shown).

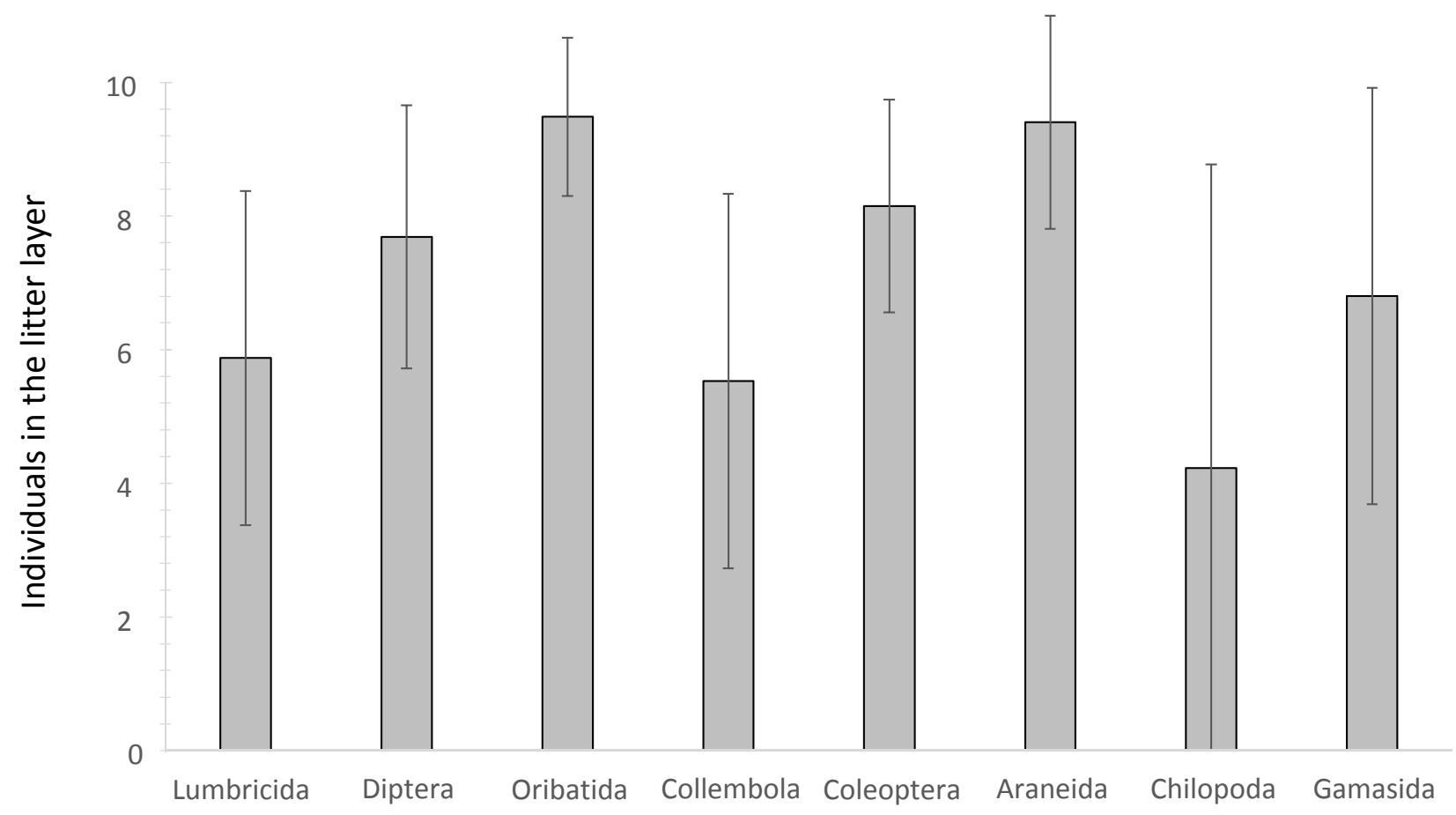

Figure 3 Individuals of soil animal groups in the litter layer as percentages of total, i.e. of those in both the litter and $0-3 \mathrm{~cm}$ of the soil; means with standard deviation. 


\section{Discussion}

We analysed the impact of management of permanent grassland, i.e. fertilizer addition, cutting frequency and herbicide application targeting either dicotyledons or monocotyledons, on biomass, activity and composition of microorganisms and abundance of soil animals. Microbial biomass and soil arthropods (dipterans and beetles) responded to cutting frequency and fertilizer addition, whereas fungal abundance and earthworm abundance to sward composition.

In swards cut once microbial biomass decreased with fertilization, supporting earlier findings that soil microorganisms in grassland are negatively affected by fertilization (de Vries et al. 2007), presumably due to reduced release of root $C$ into the rhizosphere (Marschner et al. 1996), which has been suggested to be responsible for changes in soil microbial growth (Eisenhauer et al. 2010). However, in swards cut thrice microbial biomass did not decline with fertilizer addition suggesting that cutting frequency alleviates the detrimental effect of fertilizer input, presumably due to higher root exudation (Mawdsley and Bardgett 1997; Guitian and Bardgett 2000). Interestingly, fungal PLFA but not bacterial PLFAs varied with sward composition, supporting earlier findings that fungi more sensitively respond to changes in plant functional groups than bacteria (Lange et al. 2014). In our study a higher fungal biomass was associated with MR, as compared to the DR and Ctr sward. In line Smith et al. (2008) found the fungal-to-bacterial ratio to be higher in swards dominated by forbs including legumes, whereas Lange et al. (2014) found legumes to negatively affect fungal biomass. Further studies are needed to uncover the mechanisms how sward composition affects the relationship between bacteria and fungi in soil.

As expected, fertilizer addition increased the abundance of some taxa of soil invertebrates, namely beetles and dipterans, but the opposite was true for entomobryid collembolans and in trend also for oribatid mites. However, in general the effect of fertilizer addition on the abundance of most soil invertebrate taxa was minor e.g., total collembolans and all other collembolan groups except Entomobryidae did not respond significantly to experimental treatments. Earlier studies reported inconsistent response of soil invertebrates to $\mathrm{N}$ fertilization with increases or decreases in abundances typically being limited to certain taxa and most taxa being unresponsive (Bardgett and Cook 1998; Cole et al. 2005, 2008; Eisenhauer et al. 2013). This contrasts the aboveground systems where fertilizer-induced higher plant biomass and 
increased plant nutrient concentrations generally resulting in increased abundances of arthropods in particular that of herbivore taxa (Haddad et al. 2000; Siemann 1998). Dipterans either increased or did not respond to mineral fertilizer addition (Frouz 1999). In our study dipterans increased significantly with fertilization, suggesting that they benefited from higher resource supply, which is consistent with the findings of Frouz (1999) that the biomass of dipteran larvae increased with increased plant litter input in unmown meadows. Similarly, in our study the abundance of dipterans decreased with higher cutting frequency suggesting that it was mainly due to detritivorous taxa. Interestingly, other groups of mainly detritivorous taxa, i.e. entomobryid collembolans and oribatid mites, respond in the opposite way with the abundance decreasing with fertilization. Most entomobryid collembolans and oribatid mite species are secondary decomposers relying on microorganism as food (Schneider et al. 2004; Chahartaghi et al. 2005; Maraun et al. 2011), the decline in abundance in these groups therefore likely was due to reduced microbial biomass in fertilized treatments.

Epigeic earthworms were more abundant in MR than DR sward. Feeding on litter epigeic earthworms heavily rely on high quality food resources such as legume litter (Gastine et al. 2003). Therefore, they likely benefited from reduced proportion of grasses and increased proportion of herbs, in particular legumes, in MR sward. Supporting this conclusion root $N$ concentrations of herbs at the study site were higher than those of grasses (Leuschner et al. 2013).

The majority of beetles at our study sites comprised Staphylinidae, which typically live as generalist predators, feeding on small arthropods (Bohac 1999). As the abundance of microarthropods was little affected by experimental treatments variations in the abundance of staphylinid beetles likely was due to different abundances of dipteran larvae. Indeed, the abundance of beetles increased parallel to that of dipterans in fertilized treatments as well as in treatments cut only once per year. However, beetles may also have benefited from denser vegetation in treatments with fertilizer addition and only one cut per year as Staphylinidae prefer shaded microhabitats (Bohac 1999; Dauber et al. 2005). Further, lower cutting frequency may have improved overwintering conditions of Staphylinidae (Collins et al. 2003). The more pronounced response of beetles and dipterans to experimental treatments as compared to other taxa studied likely was due to the fact that both are good dispersers enabling them to aggregate at sites with favourable environmental conditions and ample food supply. 
In accordance to our hypotheses some soil animal groups significantly responded to the studied variations in grassland management. However, in general, soil animals responded little to the studied management practices and variations in sward composition. Potentially, the low responsiveness was due to the relatively short time the experiment was lasting, as it was set up only two years before taking samples. A number of studies stressed the need for long term studies lasting several years allowing evaluation of management effects on soil organisms (Wardle et al. 1999; Gastine et al. 2003). Eisenhauer et al. (2012) emphasised the time lag between changes in plant diversity and community composition and the response of the belowground system, due to buffering by the pool of soil organic matter. Generally, the importance of soil history for current soil processes and soil community structure and functioning, i.e. the legacy of soil, is increasingly recognized (Elgersma et al. 2011; de Vries et al. 2012; Allison et al. 2013). Also, it has to be considered that abundances of arthropods vary considerably with season and year due to changes in biotic and abiotic conditions (Boyer et al. 2003; Yang et al. 2008), which we did not record in present study.

As indicated by the significant response of microorganisms, with microbial biomass responding to the interaction of cutting frequency and fertilizer addition, and fungal abundances responding to sward composition, microorganisms are more sensitively responding to changes in grassland management than soil invertebrates. The more sensitive response of microorganisms also is reflected by the fact that fertilizer addition and cutting frequency interactively affected microbial biomass, with higher cutting frequency lessening the detrimental effect of fertilizer addition. Notably, the response of soil invertebrates was most pronounced in taxa at the base of the food web such as (detritivorous) dipterans, earthworms, entomobryid collembolans and in trend oribatid mites, suggesting that management effects diminish at higher trophic levels and the direction of effects varies among taxa, presumably due to changes in the availability of food resources. The results indicate that microbial parameters more sensitively respond to intensification of management practices in grassland than soil animals, at least early after changes of management practices. Studies lasting several years are needed to clarify if this also holds in the long term. 


\section{Acknowledgements}

The study formed part of the Cluster of Excellence 'Functional Biodiversity Research' funded by the Ministry of Science and Culture of Lower Saxony and the 'Niedersächsisches Vorab'. We thank Mark Maraun for advice in data analysis, Christel Fischer for help in sorting mesofauna and Guido Humpert for support in the laboratory.

\section{References}

Allison SD, Lu Y, Weihe C, Goulden ML, Martiny AC, Treseder KK, Martiny JBH (2013) Microbial abundance and composition influence litter decomposition response to environmental change. Ecology 94, 714-725.

Anderson J, Domsch K (1978) A physiological method for the quantitative measurement of microbial biomass in soils. Soil Biology and Biochemistry 10, 215-221.

Bardgett RD, Cook R (1998) Functional aspects of soil animal diversity in agricultural grasslands. Applied Soil Ecology 10, 263-276.

Bazot S, Ulff L, Blum H, Nguyen C, Robin C (2006) Effects of elevated $\mathrm{CO}_{2}$ concentration on rhizodeposition from Lolium perenne grown on soil exposed to 9 years of $\mathrm{CO}_{2}$ enrichment. Soil Biology and Biochemistry 38, 729-736.

Beck T, Joergensen R, Kandeler E, Makeschin F, Nuss E, Oberholzer HR, Scheu S (1997) An interlaboratory comparison of ten different ways of measuring soil microbial biomass C. Soil Biology and Biochemistry 29, 1012-1032.

Beck T, Öhlinger R, Baumgarten A (1993) Bestimmung der Biomasse mittels substratinduzierter Respiration (SIR). In: Schinner F, Öhlinger R, Kandeler E, Margesin R (eds) Bodenbiol. Arbeitsmethoden, 2nd ed. Springer, Berlin, pp 68-72

Bohac J (1999) Staphylinid beetles as bioindicators. Agriculture, Ecosystems and Environment 74, 357-372.

Boyer AG, Swearingen RE, Blaha MA, Fortson CT, Gremillion SK, Osborn KA, Moran MD (2003) Seasonal variation in top-down and bottom-up processes in a grassland arthropod community. Oecologia 136, 309-316.

Chahartaghi M, Langel R, Scheu S, Ruess L (2005). Feeding guilds in Collembola based on nitrogen stable isotope ratios. Soil Biology and Biochemistry 37, 1718-1725.

Cole L, Buckland SM, Bardgett RD (2008) Influence of disturbance and nitrogen addition on plant and soil animal diversity in grassland. Soil Biology and Biochemistry 40, 505-514. 
Cole L, Buckland SM, Bardgett RD (2005) Relating microarthropod community structure and diversity to soil fertility manipulations in temperate grassland. Soil Biology and Biochemistry 37, 1707-1717.

Collins KL, Boatman ND, Wilcox A, Holland JM (2003). Effects of different grass treatments used to create overwintering habitat for predatory arthropods on arable farmland. Agriculture, Ecosystems and Environment 96, 59-67.

Dauber J, Purtauf T, Allspach A, Frisch J, Voigtländer K, Wolters V (2005) Local vs. landscape controls on diversity: a test using surface-dwelling soil macroinvertebrates of differing mobility. Global Ecology and Biogeography 14, 213-221.

De Deyn GB, Quirk H, Yi Z, Oakley S, Ostle NJ, Bardgett RD (2009) Vegetation composition promotes carbon and nitrogen storage in model grassland communities of contrasting soil fertility. Journal of Ecology 97, 864-875.

De Vries FT, Bloem J, van Eekeren N, Brusaard L, Hoffland E (2007) Fungal biomass in pastures increases with age and reduced N input. Soil Biology and Biochemistry 39, 1620-1630.

De Vries FT, Liiri ME, Bjørnlund L, Setälä HM, Christensen S, Bardgett RD (2012) Legacy effects of drought on plant growth and the soil food web. Oecologia 170, 821-33.

Eisenhauer N, Beßler H, Engels C, Gleixner G, Habekost M, Milcu A, Partsch S, Sabais ACW, Scherber C, Steinbeiss S, Weigelt A, Weisser WW, Scheu S (2010) Plant diversity effects on soil microorganisms support the singular hypothesis. Ecology 91, 485-496.

Eisenhauer N, Dobies T, Cesarz S, Hobbie SE, Meyer RJ, Worm K, Reich PB (2013) Plant diversity effects on soil food webs are stronger than those of elevated $\mathrm{CO}_{2}$ and $\mathrm{N}$ deposition in a long-term grassland experiment. Proceedings of the National Academy of Sciences 110, 6889-6894

Eisenhauer N, Reich PB, Scheu S (2012) Increasing plant diversity effects on productivity with time due to delayed soil biota effects on plants. Basic and Applied Ecology 13, 571-578.

Elgersma KJ, Ehrenfeld JG, Yu S, Vor T (2011) Legacy effects overwhelm the short-term effects of exotic plant invasion and restoration on soil microbial community structure, enzyme activities, and nitrogen cycling. Oecologia 167, 733-45.

Fornara DA, Tilman D (2008) Plant functional composition influences rates of soil carbon and nitrogen accumulation. Journal of Ecology 96, 314-322.

Frostegård A, Tunlid A, Bååth E (1991) Microbial biomass measured as total lipid phosphate in soils of different organic content. Journal of Microbiol Methods 14, 151-163.

Frouz J (1999) Use of soil dwelling Diptera (Insecta, Diptera) as bioindicators: a review of ecological requirements and response to disturbance. Agriculture, Ecosystems and Environment 74, 167-186. 
Gastine A, Scherer-Lorenzen M, Leadley P (2003) No consistent effects of plant diversity on root biomass, soil biota and soil abiotic conditions in temperate grassland communities. Applied Soil Ecology 24, 101-111.

Guitian R, Bardgett RD (2000) Plant and soil microbial responses to defoliation in temperate semi-natural grassland. Plant and Soil 220, 271-277.

Haddad NM, Haarstad J, Tilman D (2000) The effects of long-term nitrogen loading on grassland insect communities. Oecologia 124, 73-84.

Harpole WS, Tilman D (2007) Grassland species loss resulting from reduced niche dimension. Nature 446, 791-793.

Humbert JY, Ghazoul J, Richner N, Walter T (2012) Uncut grass refuges mitigate the impact of mechanical meadow harvesting on orthopterans. Biological Conservation 152, 96-101.

Isaacs R, Tuell J, Fiedler A, Gardiner M, Landis D (2009) Maximizing arthropod-mediated ecosystem services in agricultural landscapes: the role of native plants. Frontiers in Ecology and the Environment 7:196-203.

Isselstein J, Jeangros B, Pavlu V (2005) Agronomic aspects of biodiversity targeted management of temperate grasslands in Europe - A review. Agronomy Research 3, 139-151.

Kempson D, Lloyd M, Ghelardi R (1963) A new extractor for woodland litter. Pedobiologia 3, 121.

Lange $\mathrm{M}$, Habekost $\mathrm{M}$, Eisenhauer $\mathrm{N}$, Roscher $\mathrm{C}$, Bessler $\mathrm{H}$, Engels $\mathrm{C}$, Oelmann $\mathrm{Y}$, Scheu $\mathrm{S}$, Wilcke W, Schulze ED, Gleixner G (2014) Biotic and Abiotic Properties Mediating Plant Diversity Effects on Soil Microbial Communities in an Experimental Grassland. PLoS One 9:e96182.

LeBauer D, Treseder K (2008) Nitrogen limitation of net primary productivity in terrestrial ecosystems is globally distributed. Ecology 89, 371-379.

Leuschner C, Gebel S, Rose L (2013) Root trait responses of six temperate grassland species to intensive mowing and NPK fertilisation: a field study in a temperate grassland. Plant and Soil 373, 687-698.

Maraun M, Erdmann G, Fischer BM, Pollierer MM, Norton RA, Schneider K, Scheu S (2011) Stable isotopes revisited: Their use and limits for oribatid mite trophic ecology. Soil Biology and Biochemistry 43, 877-882.

Marschner H, Kirkby EA, Cakmak I (1996) Effect of mineral nutritional status on shoot-root partitioning of photoassimilates and cycling of mineral nutrients. Journal of Experimental Botany 47, 1255-1263. 
Marshall CB, McLaren JR, Turkington R (2011) Soil microbial communities resistant to changes in plant functional group composition. Soil Biology and Biochemistry 43, 78-85.

Mawdsley JL, Bardgett RD (1997) Continuous defoliation of perennial ryegrass (Lolium perenne) and white clover (Trifolium repens) and associated changes in the composition and activity of the microbial population of an upland grassland soil. Biology and Fertility of Soils 24, $52-58$.

Mouhamadou B, Puissant J, Personeni E, Desclos-Theveniau M, Kastl EM, Schloter M, Zinger L, Roy J, Geremia RA, Lavorel S (2013) Effects of two grass species on the composition of soil fungal communities. Biology and Fertility of Soils 49, 1131-1139.

Petersen U, Wrage N, Köhler L, Leuschner C, Isselstein J (2012) Manipulating the species composition of permanent grasslands - A new approach to biodiversity experiments. Basic and Applied Ecology 13, 1-9.

Ruess L, Chamberlain PM (2010) The fat that matters: Soil food web analysis using fatty acids and their carbon stable isotope signature. Soil Biology and Biochemistry 42, 1898-1910.

Sala O, Chapin F, Armesto J J, Berlow E, Bloomfield J, Dirzo R, Huber-Sanwald E, Huenneke LF, Jackson RB, Kinzig A, Leemans R, Lodge DM, Mooney HA, Oesterheld M, Poff NL, Sykes MT, Walker BH, Walker M, Wall DH (2000) Global biodiversity scenarios for the year 2100. Science 287:1770-1774.

Salamon J, Schaefer M, Alphei J, Schmid B, Scheu S (2004) Effects of plant diversity on Collembola in an experimental grassland ecosystem. Oikos 106, 51-60.

Scheu S (1992) Automated measurement of the respiratory response of soil microcompartments: active microbial biomass in earthworm faeces. Soil Biology and Biochemistry 24, 1-6.

Schneider K, Migge S, Norton RA, Scheu S, Langel R, Reineking A, Maraun M (2004) Trophic niche differentiation in soil microarthropods (Oribatida, Acari): evidence from stable isotope ratios $\left({ }^{15} \mathrm{~N} /{ }^{14} \mathrm{~N}\right)$. Soil Biology and Biochemistry 36, 1769-1774.

Siemann E (1998) Experimental tests of effects of plant productivity and diversity on grassland arthropod diversity. Ecology 79, 2057-2070.

Smith RS, Shiel RS, Bardgett RD, Millward D, Corkhill P, Evans P, Quirk H, Hobbs PJ, Kometa ST (2008) Long-term change in vegetation and soil microbial communities during the phased restoration of traditional meadow grassland. Journal of Apllied Ecology 45, 670-679.

Stoate C, Báldi A, Beja P, Boatman ND, Herzon I, van Doorn A, de Snoo GR, Rakosy L, Ramwell C (2009) Ecological impacts of early 21st century agricultural change in Europe - a review. Journal of Environmental Management 91, 22-46. 
Suding KN, Collins SL, Gough L, Clark C, Cleland EE, Gross KL, Milchunas DG, Pennings S (2005) Functional- and abundance-based mechanisms explain diversity loss due to $\mathrm{N}$ fertilization. Proceedings of the National Academy of Sciences of the United States of America 102, 4387-4392.

Ter Braak CJF, Šmilauer P (2012) Canoco Reference Manual and User's Guide: Software for Ordination (Version 5.0). Microcomputer Power, Ithaca.

Thorbek P, Bilde T (2004) Reduced numbers of generalist arthropod predators after crop management. Journal of Apllied Ecology 41, 526-538.

Tilman D, Hill J, Lehman C (2006) Carbon-Negative Biofuels from Low-Input High-Diversity Grassland Biomass. Science 314, 1598-600.

Treseder KK (2008) Nitrogen additions and microbial biomass: a meta-analysis of ecosystem studies. Ecology Letters 11, 1111-20.

Tscharntke T, Klein AM, Kruess A, Steffan-Dewenter I, Thies C (2005) Landscape perspectives on agricultural intensification and biodiversity - ecosystem service management. Ecology Letters 8, 857-874.

Van der Wal A, Geerts RHEM, Korevaar H, Schouten AJ, Jagers op Akkerhuis GAJM, Rutgers M, Mulder C (2009) Dissimilar response of plant and soil biota communities to long-term nutrient addition in grasslands. Biology and Fertility of Soils 45, 663-667.

Virágh K (1987) The effect of herbicides on vegetation dynamics: A five year study of temporal variation of species composition in permanent grassland plots. Folia Geobotanica 22, 385403.

Vitousek PM, Mooney HA, Lubchenco J, Melillo JM (1997) Human domination of Earth's ecosystems. Science 277, 494-499.

Walker KJ, Stevens PA, Stevens DP, Mountford JO, Manchester SJ, Pywell RF (2004) The restoration and re-creation of species-rich lowland grassland on land formerly managed for intensive agriculture in the UK. Biological Conservation 119, 1-18.

Wardle D, Bonner K, Barker GM, Yeates GW, Nicholson KS, Bardgett RD, Watson RN, Ghani A (1999) Plant removals in perennial grassland: vegetation dynamics, decomposers, soil biodiversity, and ecosystem properties. Ecological Monographs 69, 535-568.

Yang LH, Bastow JL, Spence KO, Wright AN (2008) What can we learn from resource pulses? Ecology 89, 621-634. 


\section{Chapter 3}

\section{Incorporation of ${ }^{13} \mathrm{C}$ labelled glucose into soil microorganisms of grassland: Effects of fertilizer addition and plant functional group composition}

Kathleen Lemanski \& Stefan Scheu
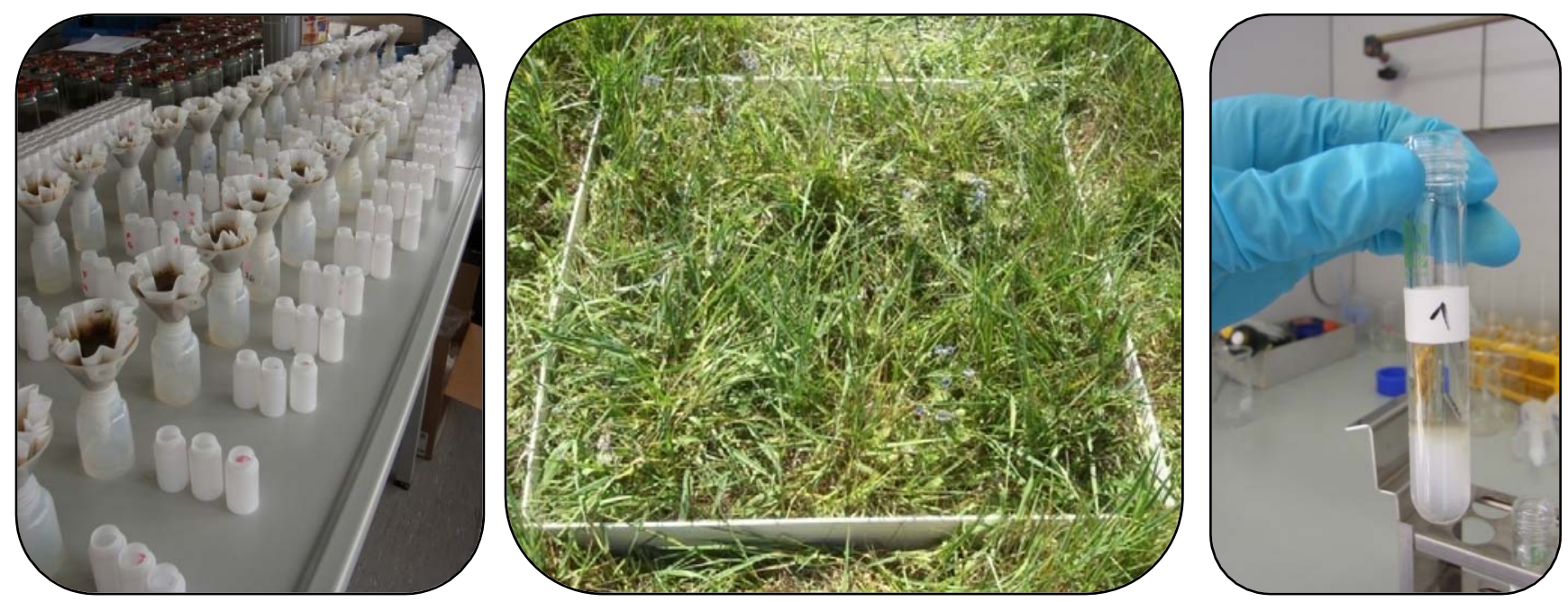

Published in: Lemanski K, Scheu S (2014) Incorporation of ${ }^{13} \mathrm{C}$ labelled glucose into soil microorganisms of grassland: Effects of fertilizer addition and plant functional group composition. Soil Biology and Biochemistry 69, 38-45. 


\section{Abstract}

In permanent grassland the influence of NPK fertilizer addition and sward composition (proportion of plant functional groups) on soil microorganisms and the incorporation of ${ }^{13} \mathrm{C}$ labelled glucose into microbial tissue were studied for 52 weeks. Microbial biomass was analysed by chloroform fumigation-extraction (CFE), soil microbial community structure by phospholipid fatty acids (PLFAs) and incorporation of labelled glucose into microorganisms by gas chromatography-combustion-isotope ratio mass spectrometry (GC-C-IRMS). ${ }^{13} \mathrm{C}$ incorporation into PLFA biomarkers suggested that after two and six weeks fungi most efficiently captured glucose C compared to later sampling dates, whereas in bacteria it remained at a similar level for 52 weeks, suggesting that microbial residues are processed predominantly by bacteria not by fungi. Further the fungal-to-bacterial atom percent excess ratio of PLFA concentrations after two and six weeks exceeded one, indicating that in relative terms initially fungi are more efficient in capturing low molecular weight $\mathrm{C}$ compounds entering the soil in pulses than bacteria. NPK fertilizer decreased soil microbial biomass and changed microbial community structure but did not affect the fungal-to-bacterial PLFA ratio. In fertilized swards the fungal-to-bacterial ${ }^{13} \mathrm{C}$ ratio increased, while bacterial ${ }^{13} \mathrm{C}$ incorporation remained at the same level, suggesting that NPK fertilizer addition increases the efficiency of resource capture by fungi. Sward composition little affected microbial community composition and glucose $\mathrm{C}$ incorporation.

\section{Keywords}

Fertilization, Microbial community structure, PLFA, Bacteria, Fungi, Microbial biomass, GC-CIRMS, Herbicide, Management 


\section{Introduction}

Soils contain large amounts of organic carbon (C) but most of this $\mathrm{C}$ is bound in complex and recalcitrant compounds, such as lignin and humic acids, and therefore is not easily available for decomposers. Low molecular weight organic matter, such as organic acids, amino acids and sugars, have short residence time in soil due to rapid uptake and assimilation by microorganisms (Van Hees et al. 2005; Rinnan and Bååth 2009). Soil microorganisms therefore are assumed to be limited predominantly by available C (Daufresne and Loreau 2001; Demoling et al. 2007). Labile compounds have been suggested to be incorporated predominantly by the 'fast' bacterial pathway, whereas recalcitrant compounds by the 'slow' fungal pathway (Moore et al. 2005; Paterson et al. 2008). The turnover time of soil bacteria presumably is in the order of days to weeks, whereas the turnover time for fungi is in the range of tens to hundreds of days (Rousk and Bååth 2011). However, there also is evidence that fungi fastly capture C from roots and efficiently use low molecular weight carbon compounds such as glucose, acetic acids and glycine (Butler et al. 2003; Rinnan and Bååth 2009). Processing of organic matter through these pathways is affected by both natural and anthropogenic disturbances, thereby affecting the way $C$ and nutrients are processed in belowground food webs (Frey et al. 2003; Moore et al. 2005; Zhang et al. 2013).

C resources enter the belowground system either via root exudates synthesized from currently assimilated C by plants ('green C') or via plant litter, i.e. dead roots and leaves ('brown C'). Generally, it is assumed that the grand majority of plant biomass enters the decomposer system as dead organic matter (Gessner et al. 2010). However, e.g. in managed grasslands, root exudates may override the importance of litter in fuelling decomposer systems as in these systems the aboveground biomass is removed as plant yield. Plants release up to $20 \%$ of the photosynthetically fixed $\mathrm{C}$ through roots (Hütsch et al. 2002), but C input via root exudates and rhizodeposits is affected by a number of factors. For example, $\mathrm{N}$ fertilization decreases $\mathrm{C}$ allocation into roots and root exudates (Marschner et al. 1996; Bazot et al. 2006), and the amount of $C$ released by roots varies between plant species (Aerts et al. 1992). Variations in root $C$ release has been suggested to be responsible for changes in soil microbial biomass and C accumulation in experimental grassland systems (Eisenhauer et al. 2010). A greater plant species number in $\mathrm{N}$ limited grassland communities enhances $\mathrm{C}$ storage in soil and roots (Fornara and Tilman 2008). However, there is evidence that $C$ accumulation does not depend 
on plant diversity per se, but rather on the presence of key plant functional groups in the plant community. Legumes play an important role in enhancing the storage of $\mathrm{C}$ and $\mathrm{N}$ in soil (Fornara and Tilman 2008; De Deyn et al. 2009). However, removal of individual plant functional groups may not necessarily translate into changes in soil microbial community composition and storage of soil C of grassland (Marshall et al. 2011).

Since the 1960s management of grasslands in Europe has been intensified continuously. High fertilizer inputs, increased mowing frequencies and herbicide application markedly enhanced grassland productivity (Isselstein et al. 2005). Changes in land use and management are among the most important drivers for the present and expected global decline in biodiversity (Vitousek et al. 1997; Sala et al. 2000; Suding et al. 2005; Harpole and Tilman 2007). The influence of management regimes including grasslands received increasing interest, as they affect major ecosystem services, such as $\mathrm{C}$ sequestration and storage in soil organic matter (Post and Kwon 2000; Jones and Donnelly 2004; Jastrow et al. 2007). Typically, in grasslands a high ratio of fungal-to-bacterial biomass has been ascribed to more natural less intensively managed ecosystems (Bardgett and McAlister 1999; Grayston et al. 2001; Zeller et al. 2001; Innes et al., 2004). However, other studies did not detect significant changes in the fungal-to-bacterial ratio with land use intensification (De Vries et al. 2007; 2013; Denef et al. 2009).

Phospholipid fatty acid (PLFA) analysis is a commonly used method for analysing the composition of soil microbial community structure (Frostegård et al. 2011) and allows to reliably determine the relative bacterial and fungal biomass in soil (Frostegård and Bååth 1996). Further, gas chromatography-combustion-isotope ratio mass spectrometry (GC-C-IRMS) is a powerful tool to follow the incorporation of $\mathrm{C}$ of different origin into soil microorganisms thereby allowing to trace the channelling of these compounds into basal decomposer taxa (Evershed et al. 2006; Bird et al. 2011; Yao et al. 2012). In this study we used PLFAs to analyse soil microbial community structure and GC-C-IRMS to follow the incorporation of labelled glucose in situ into the microbial community of temperate grassland systems as affected by NPK fertilizer addition and sward composition, i.e. variations in plant functional groups, over one year. We hypothesized that (1) bacteria have a fast incorporation of glucose, but also lose the incorporated glucose $\mathrm{C}$ fast due to high tissue turnover, whereas fungi have a slow incorporation, but a more stable $\mathrm{C}$ pool, (2) fertilizer addition increases the incorporation of glucose $\mathrm{C}$ into soil microorganisms by reducing possible microbial nutrient limitation, and (3) 
increase in dicotyledonous plants (especially legumes) increases the incorporation of glucose C as rhizosphere microorganisms of legumes are used to process high amounts of root exudates including glucose.

\section{Material and methods}

\section{Study site and experimental design}

The experiment was carried out within the framework of the 'GRASSMAN' (Grassland Management) experiment investigating consequences of grassland management intensity and sward composition for grassland functionality (Petersen et al. 2012). The study site is located in the Solling mountains (Germany, $51^{\circ} 44^{\prime} \mathrm{N}, 9^{\circ} 23^{\prime} \mathrm{E} ; 490 \mathrm{~m}$ a.s.I.). Mean annual temperature is $6.9^{\circ} \mathrm{C}$ and mean annual precipitation is $1031 \mathrm{~mm}$ (average of 1969-1990; German Weather Service). Prior to the experiment the site was used for extensive cattle grazing. Vegetation is classified as nutrient poor montane mesic Lolio-Cynosuretum. The soil is characterized as Haplic Cambisol.

The experiment was set up in 2008 in a full factorial design comprising the factors sward composition (three levels differing in the proportion of plant functional groups) and fertilization (two levels). Each treatment level was replicated six times. For setting up the experiment the site was mown and plots of a size of $15 \times 15$ m were established. Sward types of different plant composition were established by applying herbicides targeting either dicotyledons or monocotyledons resulting in sward types reduced in dicotyledons (DR) or monocotyledons (MR); plots not treated with herbicides served as control (C). In 2011 the proportion of plant functional groups were 75.0, 68.1 and $71.7 \%$ for grasses, 24.6, 29.9 and $26.9 \%$ for herbs, and 0.5, 2.0 and $1.4 \%$ for legumes in DR, MR and C treatments, respectively (T. From, unpubl. data). Fertilization treatments included NPK fertilizer addition (+NPK) and no fertilizer addition (-NPK). Fertilization started in 2008 with the addition of Nand was continued in 2009 until 2012 by the addition of $\mathrm{N}$ fertilizer, which was split into two equal applications per year while the combined $\mathrm{P}$ and $\mathrm{K}$ fertilizer was applied once a year, resulting in the application of 180-30-100 kg N-P-K $\mathrm{ha}^{-1} \mathrm{y}^{-1}$ on respective plots. All plots were mown annually in July. 


\section{${ }^{13}$ Clabelling}

In May $20110.5 \mathrm{~g}{ }^{13} \mathrm{C}$ labelled glucose $\left(99\right.$ atom $\%{ }^{13} \mathrm{C}$ ) dissolved in $500 \mathrm{ml}$ water was applied to an enclosed area of $0.5 \times 0.5 \mathrm{~m}$ at each plot. Soil samples were taken after two weeks (June 2011), six weeks (July 2011), 18 weeks (October 2011) and 52 weeks (May 2012). For each sample two soil cores of a diameter of $5 \mathrm{~cm}$ to a depth of $5 \mathrm{~cm}$ were taken, mixed, homogenized and sieved $(2 \mathrm{~mm})$. An aliquot of the samples were adjusted to a gravimetric water content of approximately $50 \%$ of the water holding capacity of the soil and used for microbial biomass determination, the remaining soil was stored at $-20^{\circ} \mathrm{C}$ and used for fatty acid analysis. Control samples were taken the year before (2010) for analysing natural variations in stable isotope ratios.

\section{Microbial biomass}

Soil microbial biomass $\left(\mathrm{C}_{\text {mic }}\right)$ was determined using the chloroform fumigation-extraction (CFE) method (Vance et al., 1987). Samples were extracted with $60 \mathrm{ml}$ of $0.05 \mathrm{M}$ potassium sulphate $\left(\mathrm{K}_{2} \mathrm{SO}_{4}\right)$ (Potthoff et al., 2003). Filtrates for analysing microbial biomass were frozen until measurement with Dohrmann DC-80 Carbon analyser equipped with an infrared detector (Rosemount Analytical Division, Santa Clara, USA) using ultraviolet enhanced persulfate oxidation. Microbial biomass C was calculated using a $k_{\mathrm{EC}}$ value of 0.45 (Wu et al., 1990). Further, filtrates were used for ${ }^{13} \mathrm{C}$ analysis by drying aliquots at $50^{\circ} \mathrm{C}$ and transferring the dry material into tin capsules. ${ }^{13} \mathrm{C}$ concentrations were analysed using a NA1500 elemental analyser (Fisons-Instruments, Milan, Italy) coupled with a Conflo III interface (Thermo Electron, Bremen, Germany) to a Finnigan MAT Delta plus isotope ratio mass spectrometer (Bremen, Germany).

Incorporation of ${ }^{13} \mathrm{C}$ into microbial biomass was calculated as ${ }^{13} \mathrm{C}_{\text {mic }}=\left(F_{\text {labelled }}-\mathrm{F}_{\text {control }}\right) \times \mathrm{C}_{\text {mic }}$, with $F_{\text {labelled }}$ the fraction of ${ }^{13} \mathrm{C}$ in the labelled sample, $F_{\text {control }}$ the fraction of ${ }^{13} \mathrm{C}$ in the unlabelled control sample and $\mathrm{C}_{\text {mic }}$ the amount of ${ }^{13} \mathrm{C}$ in the labelled sample, expressed as $\mu \mathrm{g}{ }^{13} \mathrm{C}$ incorporated g-1 soil; $F$ was calculated as $F=R /(R+1)$, with $R$ the ${ }^{13} C /{ }^{12} C$ ratio in the respective sample (Nold et al. 1999). 
Fatty acid analysis

From the six replicates four were selected at random for fatty acid analysis. Lipid extraction followed Frostegård et al. (1991). FAs were analysed by gas chromatography using Clarus 500 (Perkin Elmer, Waltham, USA). PLFAs a15:0, i15:0, i16:0 and i17:0 were used as marker FAs for gram positive bacteria, cy17:0 and cy19:0 as marker PLFAs for gram negative bacteria, 18:2 $\omega 6,9$ as saprotrophic fungal marker, $16: 1 \omega 7$ and $18: 1 \omega 7$ as unspecific bacterial marker and 22:0 and 24:0 as marker for plants (Ruess and Chamberlain, 2010). The NLFA 16:1 $\omega 5$ was used as marker for arbuscular mycorrhizal (AM) fungi (Olsson et al. 1997; Ngosong et al. 2012). As ${ }^{13} \mathrm{C}$ concentrations of the NLFA 16:1 $\omega 5$ did not differ from unlabelled control samples in half of the samples, we did not analyse the second half.

The isotopic composition of individual FAs was analysed by gas-chromatography-combustionisotope-ratio-monitoring mass spectrometer (GC-C-IRMS) using Thermo Finnigan Trace GC coupled via a GP interface to a Delta Plus mass spectrometer (Finnigan, Bremen, Germany). To verify correct identification of FAs some samples were analysed by GC-MS using a Varian CP3800 chromatograph coupled to a $1200 \mathrm{~L}$ mass spectrometer (Varian, Palo Alto, USA). The measured isotope ratios were corrected for the additional methanol group added during transesterification using the procedure of Abraham et al. (1998).

One quarter of the samples was measured twice to estimate variations in stable isotope signatures due to handling and machine errors. The variation was negligible in comparison to the variation between replicate samples; therefore, the other three quarters of the samples were measured only once.

Carbon isotope ratios are reported in $\delta$ notation (\%o) relative to Vienna Pee Dee Belemnite standard (V-PDB) calculated as $\delta^{13} \mathrm{C}=\left(\mathrm{R}_{\text {sample }} / \mathrm{RV}_{\mathrm{P}-\mathrm{PDB}}-1\right) \times 1000$, with $\mathrm{R}_{\text {sample }}$ and $\mathrm{R}_{\mathrm{V}-\mathrm{PDB}}$ the ${ }^{13} \mathrm{C} /{ }^{12} \mathrm{C}$ ratios of the sample and V-PDB $(0.0111802)$, respectively. Samples with the mean $\delta^{13} \mathrm{C}$ values of PLFAs differing from the mean $\delta^{13} \mathrm{C}$ of control samples $(-27.44)$ by less than the average standard deviation of samples measured twice, i.e. by less than $5.64 \delta$ units, were assumed not to be labelled and excluded from the analysis. This was the case for eight samples. For all others samples ${ }^{13} \mathrm{C}$ incorporation into individual PLFAs was calculated as ${ }^{13} \mathrm{C}_{\mathrm{PLFA}}=\left(\mathrm{F}_{\text {labelled }}\right.$ - $\left.F_{\text {control }}\right) \times$ PLFA described for $\mathrm{C}_{\text {mic }}$ (see above). PLFA concentrations are expressed as $\mathrm{ng}{ }^{13} \mathrm{C}$ incorporated $\mathrm{g}^{-1}$ soil (Nold et al. 1999). 
${ }^{13} \mathrm{C}$ atom percent excess (APE) of individual PLFAs were calculated as APE $=100 \times\left[\left({ }^{13} \mathrm{C}\right.\right.$ labelled $/$ $\left.\left.\left({ }^{13} C_{\text {labelled }}+{ }^{12} C_{\text {labelled }}\right)\right)-\left({ }^{13} C_{\text {control }} /\left({ }^{13} C_{\text {control }}+{ }^{12} C_{\text {control }}\right)\right)\right]$, with ${ }^{13} C_{\text {labelled }}$ and ${ }^{12} C_{\text {labelled }}$ the abundance of carbon atoms and corresponding isotopes in the labelled samples and ${ }^{13} \mathrm{C}_{\text {control }}$ and ${ }^{12} C_{\text {control }}$ the respective amount in the unlabelled control samples.

\section{Statistical analysis}

The effect of fertilizer, sward type and sampling time on absolute values of PLFAs (total bacterial PLFAs and fungal PLFA), ratios of PLFAs (fungal-to-bacterial PLFA ratio and gram negative-to-gram positive PLFA ratio) and relative abundances (percentages) based on molar concentration of individual PLFAs were analysed by repeated measures MANOVA. The effect of fertilizer, sward type and sampling time on $C_{\text {mic }},{ }^{13} \mathrm{C}$ incorporation into $C_{\text {mic }}$ and $A M$ fungal NLFA were analysed by repeated measures ANOVA. ${ }^{13} \mathrm{C}$ incorporation into PLFAs, ratios of ${ }^{13} \mathrm{C}$ incorporation and differences in $\delta^{13} \mathrm{C}$ signatures ( $\mathrm{AM}$ and plant marker) were analysed using repeated measures General Linear Model (GLM) accounting for missing values.

Profiles of PLFAs (percentages of total PLFA) were analysed by discriminant function analysis (DFA). DFA was carried out using STATISTICA 10 for Windows (StatSoft, Tulsa, USA). Repeated measures MANOVA and GLMs were performed using SAS 9.2 (SAS Institute, Cary, NC, USA).

Prior to the analyses relative abundances of PLFA expressed in percentages were arcsinesquare root transformed and all other data were log transformed to improve homogeneity of variance. Means given in text and tables are based on non-transformed data.

\section{Results}

\section{Microorganisms}

$C_{\text {mic }}$ was on average $725 \pm 18$ (SE) $\mu \mathrm{g} \mathrm{C} \mathrm{g-1}$ dry wt but significantly varied with fertilizer and time (significant fertilizer $\times$ time interaction, Table 1). On average the addition of fertilizer decreased $C_{\text {mic }}$ by $20 \%$ but the decline was less pronounced at later sampling dates; two weeks after glucose addition it decreased by 35\% (from 866 to $566 \mu \mathrm{g} \mathrm{C} \mathrm{g}{ }^{-1}$ dry wt), after six weeks by $18 \%$ 
(from 933 to $769 \mu \mathrm{g} \mathrm{C} \mathrm{g}{ }^{-1}$ dry wt) and after 18 and 52 weeks by $12 \%$ (from 722 and 696 to 637 and $614 \mu \mathrm{g} \mathrm{C} \mathrm{g}{ }^{-1}$ dry wt, respectively).

The amount of total bacterial PLFAs decreased with fertilization by $20 \%$. Fungal PLFA after 52 weeks significantly exceeded that at the three earlier sampling dates by on average $47 \%$ (Table 1 and 2). The amount of NLFA 16:1w5 in non-fertilized as compared to fertilized treatments was increased on average by $126 \%$, however, it varied significantly with time. It was similar at the first two sampling dates in two and six weeks after glucose addition, increased by $9 \%$ after 18 weeks and then decreased after 52 weeks by $37 \%$ (Table 1 and 2). The fungal-to-bacterial PLFA ratio in MR swards significantly exceeded that in DR swards on average by $24 \%$, again the C sward was intermediate (+7\% as compared to the DR sward). The fungal-to-bacterial PLFA ratio varied with season; it was at a maximum after 52 weeks exceeding the level of the three dates of the previous year by on average 36\%. Gram negative PLFA was less abundant than gram positive as indicated by the ratio between the two. In fertilized treatments this ratio further decreased significantly by $6 \%$. Gram negative-to-gram positive bacteria ratio varied with season; it was at a maximum after 52 weeks exceeding the ratio from after six weeks by $7 \%$.

As indicated by PLFA composition microbial community structure changed significantly with time. Two and six weeks after glucose addition PLFA composition differed only slightly, whereas at each of the other sampling dates PLFA composition differed significantly between each other, mainly due to FAs i17:0 and cy17:0 (DFA; $F_{30,244}=7.58, P<0.001$ ). As there were no significant interactions with time data were pooled for time. PLFA composition differed significantly between fertilized and non-fertilized treatments. Further, in non-fertilized treatments the DR sward differed from the $C$ and MR sward (DFA; $F_{50,372}=2.87, P<0.001$; Fig. 1 and Table 3). PLFA i16:0 and in trend PLFAs a15:0 and 16:1w7 contributed to the separation of the treatments in DFA space. Protected ANOVAs suggested that relative amounts of the gram positive bacterial markers a15:0 and i16:0 in fertilization treatments exceeded those in treatments without fertilization, in FA a15:0 with the differences increasing in the order C $<$ DR $<M R$ sward (fertilizer $x$ sward type interaction; $F_{2,69}=5.21, P=0.008$ and $F_{1,69}=11.70, P=$ 0.001 for PLFAs a15:0 and i16:0, respectively). By contrast, the bacterial marker 16:1w7 decreased with fertilization $\left(F_{1,69}=6.22, P=0.015\right)$. 
Table 1 Repeated measures MANOVA table of $F$ - and $P$-values on the effect of fertilizer, sward type and sampling time on $\mathrm{C}_{\text {mic }}$, bacterial PLFAs, fungal PLFAs, fungal-to-bacterial PLFA ratio, gram negative-togram positive bacteria ratio and AM fungal NLFA 16:1w5. Significant effects are given in bold. $C_{\text {mic }}$ had a significant fertilizer $x$ time interaction $\left(F_{3,25}=4.30, P=0.007\right)$ not shown in the table, none of the other interactions were significant.

\begin{tabular}{|c|c|c|c|c|c|c|}
\hline & \multicolumn{2}{|c|}{ Fertilizer } & \multicolumn{2}{|c|}{ Sward type } & \multicolumn{2}{|c|}{ Time } \\
\hline & $F$ & $P$ & $F$ & $P$ & $F$ & $P$ \\
\hline $\mathrm{C}_{\text {mic }}$ & 10.34 & 0.004 & 1.38 & 0.271 & 10.99 & $<0.001$ \\
\hline Bacterial PLFAs & 12.52 & 0.003 & 0.90 & 0.426 & 4.21 & 0.010 \\
\hline Fungal PLFA & 3.93 & 0.066 & 3.67 & 0.051 & 9.96 & $<0.001$ \\
\hline $\begin{array}{l}\text { Fungal-to-bacterial } \\
\text { PLFA ratio }\end{array}$ & 1.35 & 0.253 & 5.07 & 0.021 & 11.62 & $<0.001$ \\
\hline $\begin{array}{l}\text { Gram negative-to-gram } \\
\text { positive bacteria ratio }\end{array}$ & 9.95 & 0.007 & 0.73 & 0.499 & 6.16 & 0.001 \\
\hline AM fungal NLFA & 19.67 & 0.001 & 0.30 & 0.747 & 5.61 & 0.002 \\
\hline
\end{tabular}


Table 2 Effects of fertilizer, sward type and sampling time after addition of glucose (in weeks) on Cmic, bacterial PLFAs, fungal PLFA, fungal-to-bacterial PLFA ratio, gram negative-to- gram positive bacteria ratio and AM fungal NLFA 16:1w5. Values represent means with standard errors. Significant differences are given in bold.

\begin{tabular}{|c|c|c|c|c|c|c|c|c|c|}
\hline & \multicolumn{2}{|c|}{ Fertilizer } & \multicolumn{3}{|c|}{ Sward type } & \multicolumn{4}{|c|}{ Time } \\
\hline & $-N P K$ & $+\mathrm{NPK}$ & $\mathrm{C}$ & $\mathrm{DR}$ & $M R$ & 2 & 6 & 18 & 52 \\
\hline $\begin{array}{l}C_{\text {mic }} \\
{\left[\mu g \mathrm{Cg}^{-1} \text { soil] }\right.}\end{array}$ & $\begin{array}{l}804 \\
\pm 48\end{array}$ & $\begin{array}{l}646 \\
\pm 33\end{array}$ & $\begin{array}{l}785 \\
\pm 35\end{array}$ & $\begin{array}{l}689 \\
\pm 24\end{array}$ & $\begin{array}{l}702 \\
\pm 31\end{array}$ & $\begin{array}{l}716 \\
\pm 47\end{array}$ & $\begin{array}{l}851 \\
\pm 47\end{array}$ & $\begin{array}{l}680 \\
\pm 28\end{array}$ & $\begin{array}{l}655 \\
\pm 41\end{array}$ \\
\hline $\begin{array}{l}\text { Bacterial PLFAs } \\
{\left[\mathrm{nmol} \mathrm{g}^{-1} \text { soil] }\right.}\end{array}$ & $\begin{array}{l}79.20 \\
\pm 2.50\end{array}$ & $\begin{array}{l}63.64 \\
\pm 2.21\end{array}$ & $\begin{array}{l}75.91 \\
\pm 3.49\end{array}$ & $\begin{array}{l}68.25 \\
\pm 2.41\end{array}$ & $\begin{array}{l}70.09 \\
\pm 3.50\end{array}$ & $\begin{array}{l}64.89 \\
\pm 4.05\end{array}$ & $\begin{array}{l}74.71 \\
\pm 3.30\end{array}$ & $\begin{array}{l}71.62 \\
\pm 3.83\end{array}$ & $\begin{array}{l}74.45 \\
\pm 3.38\end{array}$ \\
\hline $\begin{array}{l}\text { Fungal PLFA } \\
{\left[\mathrm{nmol} \mathrm{g}^{-1} \text { soil] }\right.}\end{array}$ & $\begin{array}{l}1.81 \\
\pm 0.10\end{array}$ & $\begin{array}{l}1.56 \\
\pm 0.09\end{array}$ & $\begin{array}{l}1.74 \\
\pm 0.11\end{array}$ & $\begin{array}{l}1.44 \\
\pm 0.09\end{array}$ & $\begin{array}{l}1.86 \\
\pm 0.14\end{array}$ & $\begin{array}{l}1.60 \\
\pm 0.16\end{array}$ & $\begin{array}{l}1.50 \\
\pm 0.10\end{array}$ & $\begin{array}{l}1.41 \\
\pm 0.11\end{array}$ & $\begin{array}{l}2.21 \\
\pm 0.12\end{array}$ \\
\hline $\begin{array}{l}\text { Fungal-to-bacterial } \\
\text { PLFA ratio }\end{array}$ & $\begin{array}{l}0.022 \\
\pm 0.001\end{array}$ & $\begin{array}{l}0.024 \\
\pm 0.001\end{array}$ & $\begin{array}{l}0.023 \\
\pm 0.001\end{array}$ & $\begin{array}{l}0.021 \\
\pm 0.001\end{array}$ & $\begin{array}{l}0.026 \\
\pm 0.002\end{array}$ & $\begin{array}{l}0.024 \\
\pm 0.002\end{array}$ & $\begin{array}{l}0.020 \\
\pm 0.001\end{array}$ & $\begin{array}{l}0.019 \\
\pm 0.001\end{array}$ & $\begin{array}{l}0.029 \\
\pm 0.001\end{array}$ \\
\hline $\begin{array}{l}\text { Gram negative-to-gram } \\
\text { positive bacteria ratio }\end{array}$ & $\begin{array}{l}0.49 \\
\pm 0.01\end{array}$ & $\begin{array}{l}0.46 \\
\pm 0.01\end{array}$ & $\begin{array}{l}0.48 \\
\pm 0.01\end{array}$ & $\begin{array}{l}0.48 \\
\pm 0.01\end{array}$ & $\begin{array}{l}0.46 \\
\pm 0.01\end{array}$ & $\begin{array}{l}0.46 \\
\pm 0.01\end{array}$ & $\begin{array}{l}0.46 \\
\pm 0.01\end{array}$ & $\begin{array}{l}0.47 \\
\pm 0.01\end{array}$ & $\begin{array}{l}0.50 \\
\pm 0.01\end{array}$ \\
\hline $\begin{array}{l}\text { AM fungal NLFA } \\
{\left[\mathrm{nmol} \mathrm{g}^{-1} \text { soil] }\right.}\end{array}$ & $\begin{array}{l}8.24 \\
\pm 0.61\end{array}$ & $\begin{array}{l}3.64 \\
\pm 0.38\end{array}$ & $\begin{array}{l}6.81 \\
\pm 0.81\end{array}$ & $\begin{array}{l}5.54 \\
\pm 0.59\end{array}$ & $\begin{array}{l}5.54 \\
\pm 0.82\end{array}$ & $\begin{array}{l}6.12 \\
\pm 0.88\end{array}$ & $\begin{array}{l}6.69 \\
\pm 1.06\end{array}$ & $\begin{array}{l}6.96 \\
\pm 0.81\end{array}$ & $\begin{array}{l}4.02 \\
\pm 0.48\end{array}$ \\
\hline
\end{tabular}




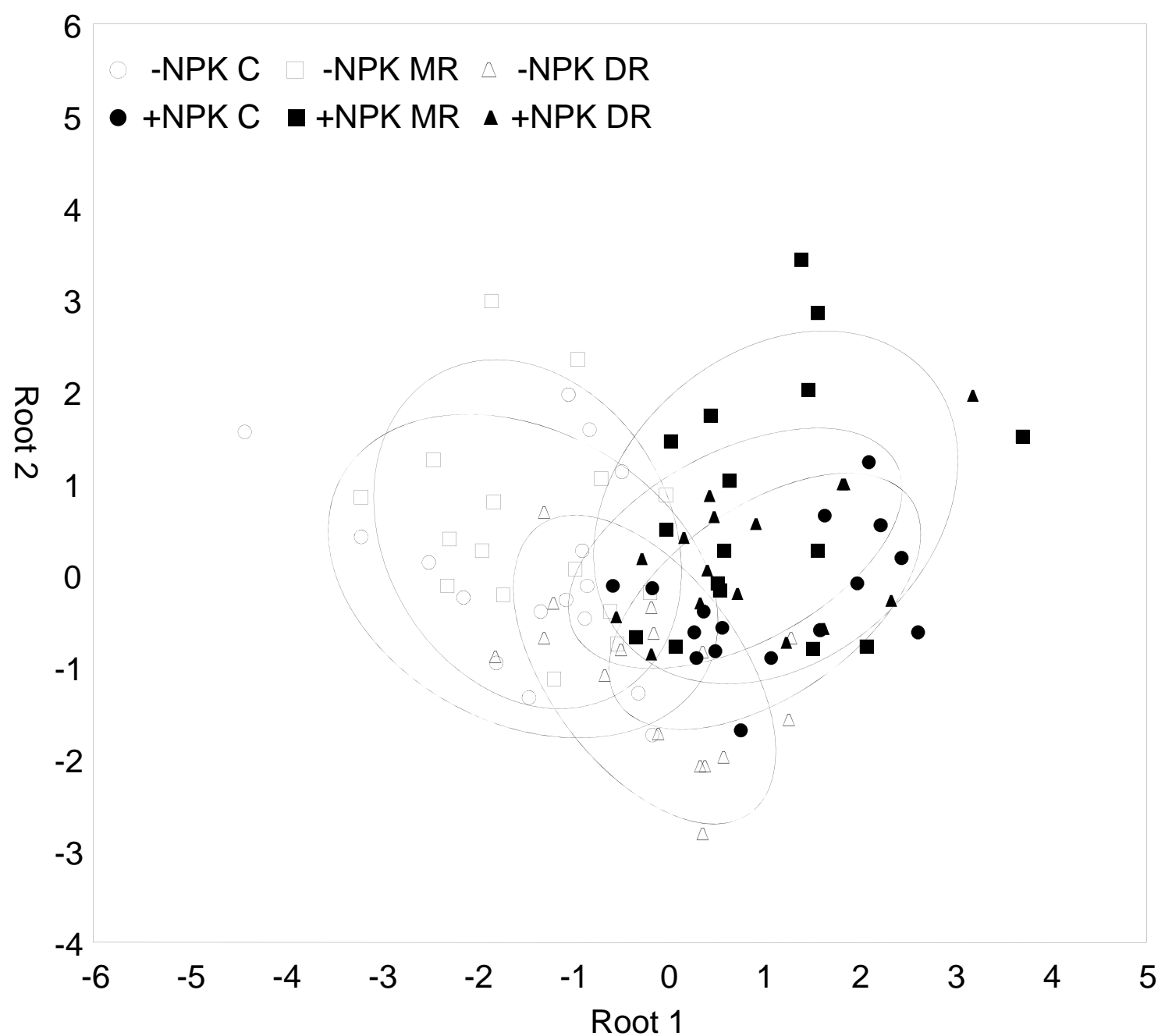

Figure 1 Differences in FA patterns between experimental treatments as indicated by discriminant

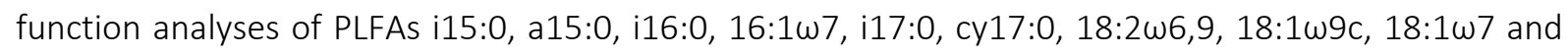
cy19:0; Wilks $\lambda F=2.87, P<0.001$; ellipses represent confidence ranges at $P<0.05$. -NPK $=$ not fertilized, $+\mathrm{NPK}=$ fertilized, $\mathrm{C}=$ Control, $\mathrm{DR}=$ Dicotyledons reduced, $\mathrm{MR}=$ Monocotyledons reduced.

Table $3 \mathrm{~F}$ - and $P$-values of Mahalanobis distances between treatment means presented in Fig. 1. Significant effects are given in bold. As there were no significant interactions with time data were pooled for time, i.e. only effects of fertilization and sward type are shown. - NPK $=$ not fertilized, + NPK $=$ fertilized, $C=$ Control, $D R=$ dicotyledons reduced, $M R=$ monocotyledons reduced.

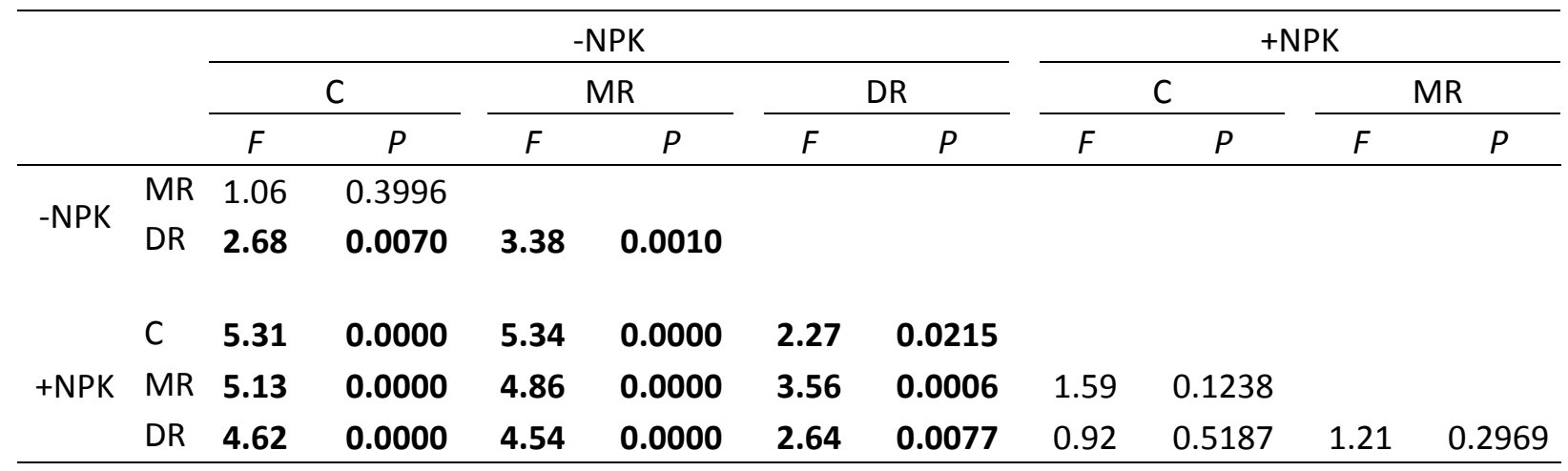


Incorporation of glucose C into microorganisms

${ }^{13} \mathrm{C}$ incorporation into $\mathrm{C}_{\text {mic }}$ in the non-fertilized MR sward two weeks after addition of glucose $\left(0.05 \mu \mathrm{g}^{13} \mathrm{C} \mathrm{g}^{-1}\right.$ ) significantly exceeded that in the other treatments (overall mean $0.01 \mu \mathrm{g}{ }^{13} \mathrm{C} \mathrm{g}^{-}$ 1; fertilizer $x$ sward $x$ time interaction; $\left.F_{6,25}=2.55, P=0.027\right) \cdot{ }^{13} \mathrm{C}$ incorporation into PLFA $18: 2 \omega 6,9$ as marker for saprotrophic fungi was at a maximum two weeks after addition of glucose and decreased by $48-71 \%$ at the following sampling dates (Fig. 3 and Table 4).The fungal-to-bacterial ratio of ${ }^{13} \mathrm{C}_{\text {PLFA }}$ increased significantly with fertilization by $61 \%$ (Fig. 2 and Table 4). It was at a maximum two weeks after addition of glucose and declined by 31 - $66 \%$ later in the experiment. Accordingly, the fungal-to-bacterial APE ratio of PLFA concentrations differed with time $\left(F_{3,15}=13.03, P<0.001\right)$. It was at a maximum after two weeks with a ratio of $1.85 \pm 0.25$ (SE), declined towards $1.34 \pm 0.21$ after six weeks and then to $0.74 \pm 0.09$ and $0.71 \pm 0.11$ after 18 and 52 weeks, respectively. In contrast, the gram negative-to-gram positive bacterial ${ }^{13} C_{\text {PLFA }}$ ratio was lowest two weeks after addition of glucose, increased by $61 \%$ after six weeks and remained at that level at the following sampling dates (Fig. 3 and Table 4).The gram negative-to-gram positive bacteria ratio decreased with fertilization in MR and $\mathrm{C}$ sward by $33 \%$ and $13 \%$ respectively, whereas it moderately increased in DR sward with fertilization by 9\% (fertilizer $x$ sward type interaction; $F_{2,15}=3.80, P=0.047$ ).

The $\delta^{13} \mathrm{C}$ value of the AM fungi marker NLFA 16:1w5 generally did not differ significantly between control and labelled samples and was on average $-29.82 \pm 0.78$. Similarly, $\delta^{13} \mathrm{C}$ values of PLFAs 22:0 and 24:0, both abundant in plants, did not significantly differ between control and labelled samples and were on average $-35.18 \pm 0.36$ and $-32.60 \pm 0.60$, respectively. 
Table 4 Repeated measures GLM table of $F$ - and $P$-values on the effect of the addition of fertilizer, sward type and sampling date on incorporation of glucose $C$ into microbial biomass $\left(C_{\text {mic }}\right)$, bacterial PLFAs and fungal PLFA as well as fungal-to-bacterial PLFA ratio and gram negative-to-gram positive PLFA ratio. Significant effects are given in bold. Gram negative-to-gram positive PLFA ratio had a significant fertilizer $x$ sward type interaction $\left(F_{2,15}=3.80, P=0.046\right)$ and $C_{\text {mic }}$ had a significant fertilizer $x$ sward type $x$ time interaction $\left(F_{6,25}=2.55, P=0.028\right)$ not shown in the table, none of the other interactions were significant.

\begin{tabular}{|c|c|c|c|c|c|c|}
\hline & \multicolumn{2}{|c|}{ Fertilizer } & \multicolumn{2}{|c|}{ Sward } & \multicolumn{2}{|c|}{ Time } \\
\hline & $F$ & $P$ & $F$ & $P$ & $F$ & $P$ \\
\hline $\mathrm{C}_{\text {mic }}$ & 2.94 & 0.099 & 1.23 & 0.310 & 11.6 & $<0.001$ \\
\hline Bacterial PLFAs & 0.00 & 0.988 & 1.02 & 0.385 & 0.27 & 0.850 \\
\hline Fungal PLFA & 3.06 & 0.100 & 0.21 & 0.811 & 5.31 & 0.003 \\
\hline $\begin{array}{l}\text { Fungal-to-bacterial } \\
\text { PLFA ratio }\end{array}$ & 4.81 & 0.045 & 0.62 & 0.553 & 9.51 & $<0.001$ \\
\hline $\begin{array}{l}\text { Gram negative-to-gram } \\
\text { positive bacteria ratio }\end{array}$ & 2.96 & 0.106 & 0.37 & 0.697 & 9.43 & $<0.001$ \\
\hline
\end{tabular}



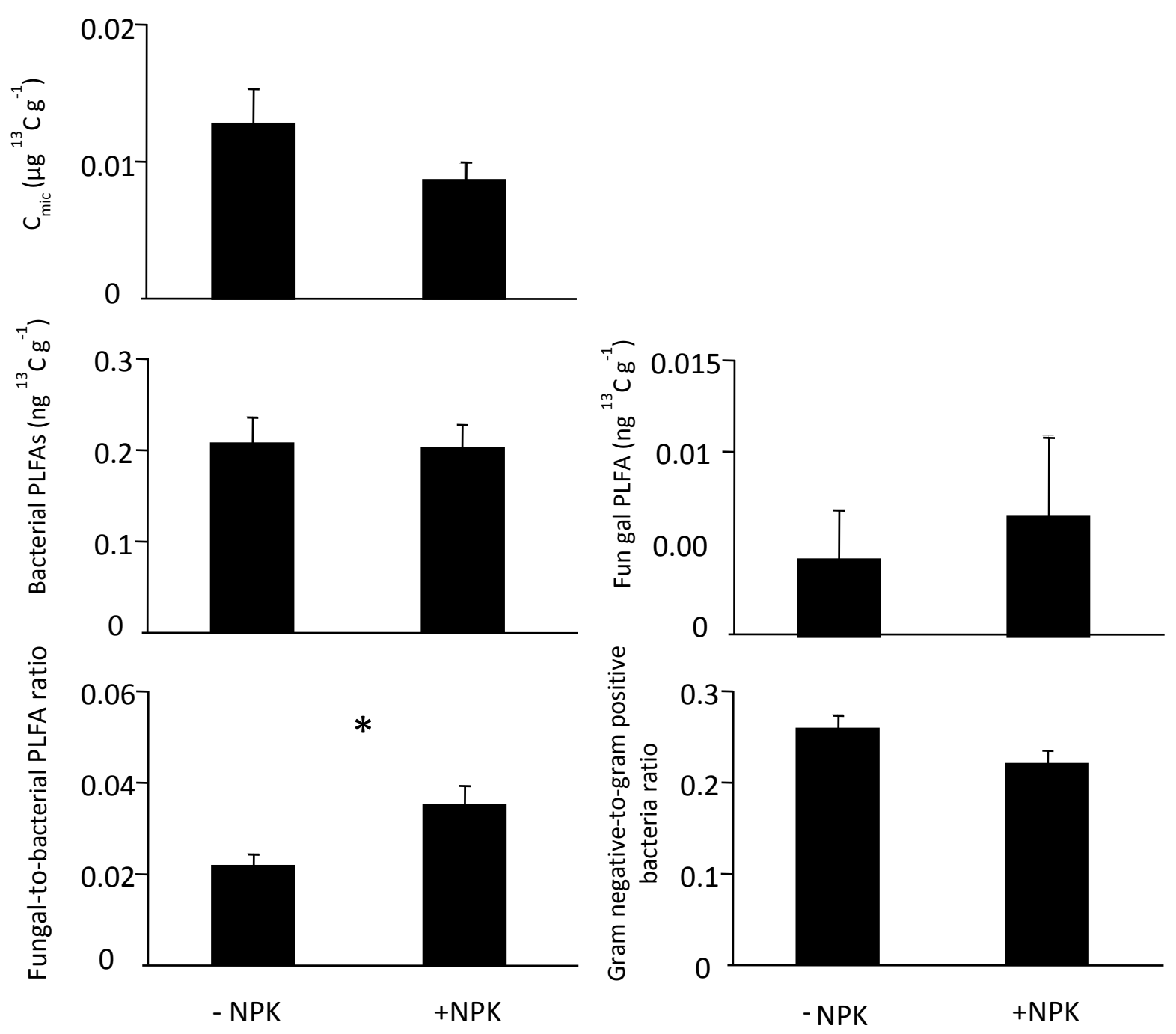

Figure 2 Effect of the addition of fertilizer on incorporation of glucose $C$ into soil microbial biomass $\left(C_{\text {mic }}\right)$, total bacterial biomass, fungal biomass, fungal-to-bacterial biomass ratio and gram negative-to-gram positive bacteria ratio; means with standard errors. Repeated measures GLM; *, $P<0.05$. 

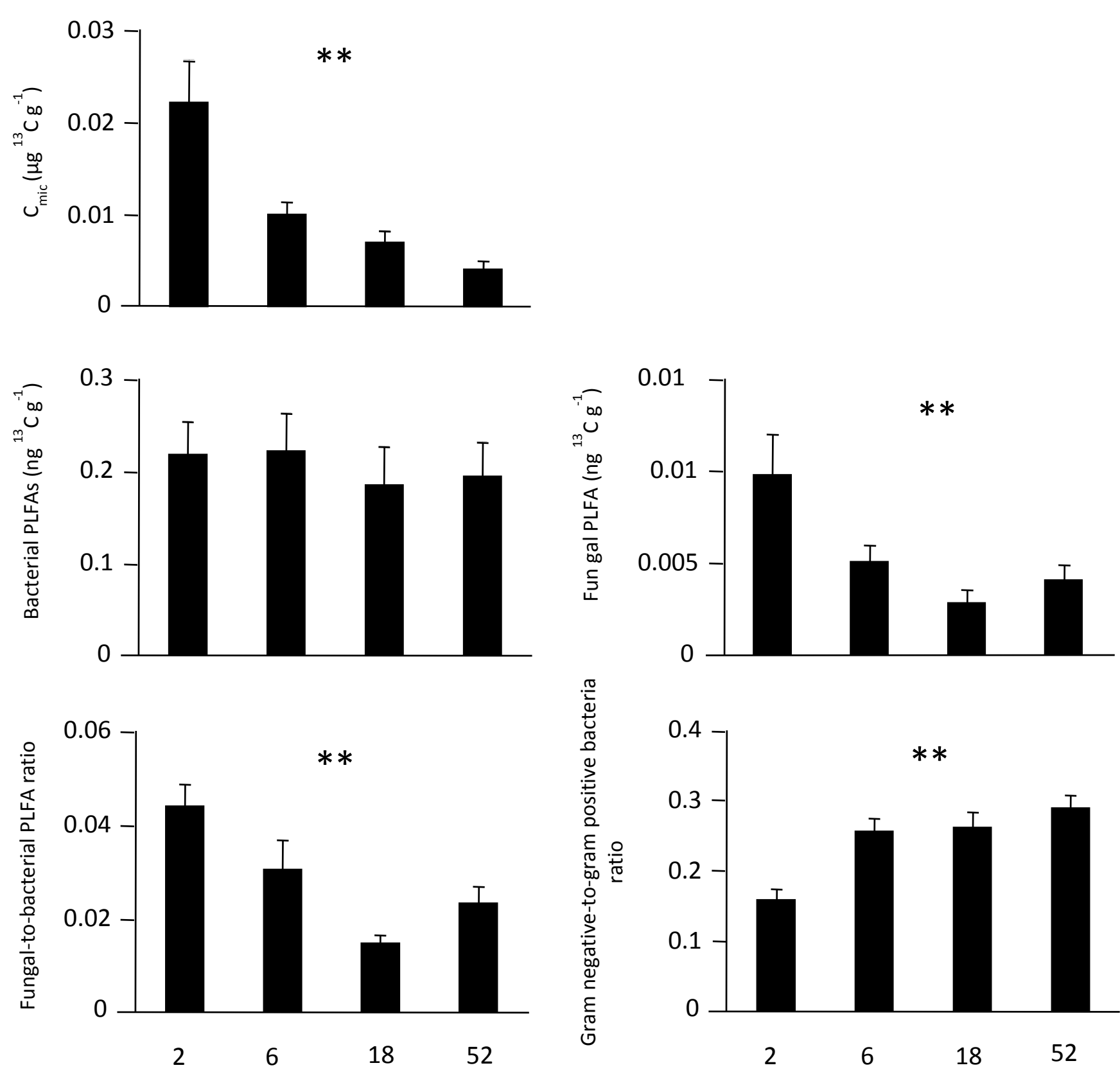

Figure 3 Variations with time (weeks after glucose addition) in incorporation of glucose $C$ into soil microbial biomass $\left(C_{\text {mic }}\right)$, total bacterial biomass, fungal biomass, fungal-to-bacterial biomass ratio and gram negative-to-gram positive bacteria ratio; means with standard errors. Repeated measures GLM; $* *, P<0.01, * * *, P<0.001$. 


\section{Discussion}

\section{Microbial community composition}

We analysed the impact of management of permanent grassland, i.e. fertilizer addition and herbicide application targeting either dicotyledons or monocotyledons, on soil microbial community structure and incorporation of labile C (glucose) into soil microorganisms. Generally, microbial community composition changed with season as indicated by changes in the fungal-to-bacterial as well as gram negative-to-gram positive bacteria ratio. Soil communities rely on resource input from dead organic matter (leaf litter and roots; 'brown C') but also from root exudates originating from recently fixed C ('green C'). Microbial biomass $\left(\mathrm{C}_{\text {mic }}\right)$ was at a maximum six weeks after addition of glucose in July coinciding with maximum rates of photosynthesis and high input of root exudates entering the soil (Kuzyakov and Cheng, 2001), underlining the importance of root derived $C$ for soil microorganisms. Differences in $C_{\text {mic }}$ between fertilized and non-fertilized treatments were less pronounced at later sampling dates, presumably due to the fertilizer application early in the experiment and the effects diminishing later.

$\mathrm{C}_{\text {mic }}$ as well as bacterial PLFA decreased with fertilization supporting earlier findings that soil microorganisms in grassland are negatively affected by fertilization (De Vries et al. 2007). Notably, the unfavourable effect of fertilization was not related to changes in root biomass and soil pH, known to regulate microbial biomass (Bååth and Anderson 2003), as both did not differ significantly between treatments (Rose and Leuschner 2012; F. Wemheuer, unpubl. data). In contrast to the root biomass the aboveground yield did increase significantly with fertilization (Petersen et al. 2013). N fertilization is known to reduce $\mathrm{C}$ allocation into roots and belowground (Marschner et al. 1996; Bazot et al. 2006), which again emphasis the dependency of microorganisms on root derived resources. In parallel also the AM fungi declined in fertilized treatments as indicated by the NLFA marker for AM fungi. This suggests that to cover the demand of nutrients in non-fertilized treatments plants more heavily invested in mycorrhizal symbionts; likely associated with an increase in $\mathrm{C}$ allocation to roots and increased $\mathrm{C}$ input into the rhizosphere. Higher abundance of AM fungi in non-fertilized as compared to $\mathrm{P}$ and/or $\mathrm{N}$ fertilized grassland has been reported previously (Son and Smith 1988; Bradley et al. 2006; Denef et al. 2009), and it has been suggested that $\mathrm{N}$ deposition disrupts the relationship between AM fungi and plants (Bradley et al. 2006). Non-fertilized grasslands generally have 
been suggested to favour fungi at the expense of bacteria (Bardgett and McAlister 1999; Grayston et al. 2001), but this is not universally the case (De Vries et al. 2007; 2013; Denef et al., 2009). In our study the fungal-to-bacterial ratio also did not respond to fertilization. However, the community structure of microorganisms differed between fertilized and nonfertilized treatments but the response varied with sward composition. In non-fertilized treatments of the DR sward microbial community structure differed from that in the control and the MR sward. This suggests that fertilization counteracted effects caused by variations in sward composition. In accordance with these findings, it has been proposed that the addition of $\mathrm{P}$ fertilizer masks the ability of plant species to shape their rhizosphere microbial community (Veresoglou et al. 2011). Further, differences in microbial community structure between DR sward and the control and MR sward, with the latter two being similar, suggests that reduction of dicotyledons more strongly influence microbial community structure than reduction of monocotyledons.

\section{Microbial incorporation of glucose carbon}

We hypothesized that bacteria incorporate glucose fast, but also lose the incorporated glucose C fast, whereas fungi have a slow incorporation, but a more stable $\mathrm{C}$ pool. In contrast to this hypothesis, fungal-to-bacterial ${ }^{13} \mathrm{CPLFA}_{\text {and }}$ APE of PLFA concentrations ratios were highest at the first sampling date (two weeks after labelling), indicating that initially fungi more efficiently captured glucose $\mathrm{C}$ than bacteria. The significant decline in the fungal-to-bacterial ${ }^{13} \mathrm{C}_{\text {PLFA }}$ and APE of PLFA concentrations ratio, the latter exceeding one at the first two sampling dates, suggests that fungi respond in a more opportunistic way to increased availability of easily available $\mathrm{C}$ resources in soil using pulses of resources but being inferior to bacteria in continuously exploiting microbial residues formed by pulsed resource input. Similar to our findings Denef et al. (2007; 2009) found $\mathrm{C}$ from pulse labelling of plants with ${ }^{13} \mathrm{CO}_{2}$ to be incorporated predominantly into fungi with the incorporation into bacteria increasing with time in grassland, underlining the ability of fungi to efficiently exploit low molecular weight organic substances such as root exudates.

Fungi are known to comprise very different functional groups with some specialized in fast exploitation of low molecular weight C compounds such as glucose (sugar fungi; Garrett 1951). Presumably, these fungi comprising predominantly Zygomycota, such as Mucor and 
Mortierella, were responsible for the fast incorporation of glucose in our experiment. Unfortunately, the fungal PLFA marker 18:2w6,9 does not allow separation of different groups of saprotrophic fungi. Despite this lack of information, the results suggest that saprotrophic fungi efficiently capture low molecular weight $\mathrm{C}$ compounds entering the soil in pulses which contrasts the widely held view that these resources are more efficiently captured by bacteria (Moore et al., 2005). Remarkably, the concentration of ${ }^{13} \mathrm{C}$ in bacterial PLFAs did not decrease significantly over the time of 52 weeks, indicating that bacteria were capable either to store $\mathrm{C}$ in stable pools or that glucose $\mathrm{C}$ used for metabolism was replaced by continuous uptake of labelled C from soil pools, presumably originating from residues of microorganisms which died during the experiment. As sequestration of labelled $C$ into inert bacterial pools is unlikely, glucose $\mathrm{C}$ used for respiration likely was replaced. Therefore, the results suggest that microbial residues are processed predominantly by bacteria not by fungi. Again, these results are conform to the finding of Denef et al. (2007), i.e. that in grassland incorporation of C from pulse labelling of plants with ${ }^{13} \mathrm{CO}_{2}$ into bacteria increases with time, which has been attributed to preferential bacterial use of dead root material or fungal necromass as $\mathrm{C}$ source. As indicated by the increase in the gram negative-to-gram positive bacteria ${ }^{13} C_{\text {PLFA }}$ ratio incorporation of $\mathrm{C}$ from microbial residues after two weeks was more pronounced in gram negative as compared to gram positive bacteria. Similarly, Zhang et al. (2013) found glucose C to be preferentially incorporated into gram positive as compared to gram negative bacteria. Elfstrand et al. (2008) suggested gram positive bacteria to be more strongly linked to Coriginating from decomposing green manure than gram negative bacteria, potentially explaining different results from $\mathrm{CO}_{2}$ pulse labelling and glucose addition experiments on the incorporation of labile $\mathrm{C}$ into gram positive as compared to gram negative bacteria (Butler et al. 2003; Bird et al. 2011; Bahn et al. 2013).

With fertilization the fungal-to-bacterial ${ }^{13} C_{\text {PLFA }}$ ratio increased, while bacterial ${ }^{13} \mathrm{C}$ incorporation remained at the same, suggesting that fungi efficiently competed with bacteria for these resources. Liljeroth et al. (1990) and Ågren et al. (2001) found the efficiency of microorganisms to be increased by $\mathrm{N}$ fertilization. Our results suggest that this is restricted to or at least more pronounced in fungi as compared to bacteria. 
Differences in sward composition little affected microbial community structure and also microbial capture of low molecular weight $C$ resources. As described above the amount of PLFAs and also the incorporation of labelled glucose differed little between sward types.

\section{Conclusion}

The results suggest that the capacity to incorporate glucose $\mathrm{C}$ in fungi is most pronounced early after glucose addition and declines later, whereas the incorporation of glucose $\mathrm{C}$ into bacteria varies little for at least 52 weeks. Further, the fungal-to-bacterial APE ratio of PLFA concentrations exceeding one after two and six weeks indicate that early after glucose addition

${ }^{13} \mathrm{C}$ concentration in fungal PLFA is higher than in bacterial PLFAs, while later the opposite is the true. This suggests that in relative terms initially fungi are more efficient in capturing low molecular weight $\mathrm{C}$ compounds entering the soil in pulses than bacteria. Further, the results suggest that microbial residues are processed predominantly by bacteria not by fungi. Supporting earlier findings the results indicate that NPK fertilization negatively affects soil microorganisms especially bacteria. However, fertilizer addition increased the efficiency of fungi but not bacteria to capture glucose $\mathrm{C}$. Differences in the composition of plant functional groups in swards little affected microbial community structure and the capture of low molecular weight $\mathrm{C}$ resources by microorganisms suggesting that incorporation into microorganisms and processing of these resources resists changes in plant community composition.

\section{Acknowledgements}

The study formed part of the Cluster of Excellence 'Functional Biodiversity Research' funded by the Ministry of Science and Culture of Lower Saxony and the 'Niedersächsisches Vorab'. We thank Mark Maraun for advice and help in data analyses, and Guido Humpert and Karin Schmidt for support in the laboratory. Sincere thanks to Martin Blumenberg for GC-MS measurements. 


\section{References}

Abraham W, Hesse C, Pelz O (1998) Ratios of carbon isotopes in microbial lipids as an indicator of substrate usage. Applied and Environmental Microbiology 64, 4202-4209.

Aerts R, Bakker C, De Caluwe H (1992) Root turnover as determinant of the cycling of C, N, and $P$ in a dry heathland ecosystem. Biogeochemistry 15, 175-190.

Ågren GI, Bosatta E, Magill AH (2001) Combining theory and experiment to understand effects of inorganic nitrogen on litter decomposition. Oecologia 128, 94-98.

Bååth E, Anderson T-H (2003) Comparison of soil fungal/bacterial ratios in a pH gradient using physiological and PLFA-based techniques. Soil Biology and Biochemistry 35, 955-963.

Bahn M, Lattanzi F A, Hasibeder R, Wild B, Koranda M, Danese V, Brüggemann N, Schmitt M, Siegwolf R, Richter A (2013) Responses of belowground carbon allocation dynamics to extended shading in mountain grassland. New Phytologist 198, 116-26.

Bardgett RD, McAlister E (1999) The measurement of soil fungal:bacterial biomass ratios as an indicator of ecosystem self-regulation in temperate meadow grasslands. Biology and Fertility of Soils 29, 282-290.

Bazot S, Ulff L, Blum H, Nguyen C, Robin C (2006) Effects of elevated $\mathrm{CO}_{2}$ concentration on rhizodeposition from Lolium perenne grown on soil exposed to 9 years of $\mathrm{CO}_{2}$ enrichment. Soil Biology and Biochemistry 38, 729-736.

Bird J A, Herman DJ, Firestone MK (2011) Rhizosphere priming of soil organic matter by bacterial groups in a grassland soil. Soil Biology and Biochemistry 43, 718-725.

Bligh E, Dyer W (1959) A rapid method of total lipid extraction and purification. Canadian Journal of Biochemestry and Physiology 37, 911-917.

Bradley K, Drijber RA, Knops J (2006) Increased N availability in grassland soils modifies their microbial communities and decreases the abundance of arbuscular mycorrhizal fungi. Soil Biology and Biochemistry 38, 1583-1595.

Butler JL, Williams MA, Bottomley PJ, Myrold DD (2003) Microbial community dynamics associated with rhizosphere carbon flow. Applied and Environmental Microbiology 69, 6793-6800.

Daufresne T, Loreau M (2001) Ecological stoichiometry, primary producer-decomposer interactions, and ecosystem persistence. Ecology 82, 3069-3082.

De Deyn GB, Quirk H, Yi Z, Oakley S, Ostle NJ, Bardgett RD (2009) Vegetation composition promotes carbon and nitrogen storage in model grassland communities of contrasting soil fertility. Journal of Ecology 97, 864-875. 
De Vries FT, Bloem J, van Eekeren N, Brusaard L, Hoffland E (2007) Fungal biomass in pastures increases with age and reduced N input. Soil Biology and Biochemistry 39, 1620-1630.

De Vries FT, Thébault E, Liiri M, Birkhofer K, Tsiafouli MA, Bjørnlund L, Bracht Jørgensen H, Brady MV, Christensen S, De Ruiter PC, d'Hertefeldt T, Frouz J, Hedlund K, Hemerik L, Hol WHG, Hotes S, Mortimer SR, Setälä H, Sgardelis SP, Uteseny K, Van der Putten WH, Wolters V, Bardgett RD (2013) Soil food web properties explain ecosystem services across European land use systems. Proceedings of the National Academy of Sciences of the United States of America 110, 14296-301.

Demoling F, Figueroa D, Bååth E (2007) Comparison of factors limiting bacterial growth in different soils. Soil Biology and Biochemistry 39, 2485-2495.

Denef K, Bubenheim H, Lenhart K, Vermeulen J, van Cleemput O, Boeckx P, Müller C (2007) Community shifts and carbon translocation within metabolically-active rhizosphere microorganisms in grasslands under elevated $\mathrm{CO}_{2}$. Biogeoscience 4, 769-779.

Denef K, Roobroeck D, Manimel Wadu MCW, Lootens P, Boeckx P (2009) Microbial community composition and rhizodeposit-carbon assimilation in differently managed temperate grassland soils. Soil Biology and Biochemistry 41, 144-153.

Eisenhauer N, Beßler H, Engels C, Gleixner G, Habekost M, Milcu A, Partsch S, Sabais ACW, Scherber C, Steinbeiss S, Weigelt A, Weisser WW, Scheu S (2010) Plant diversity effects on soil microorganisms support the singular hypothesis. Ecology 91, 485-496.

Elfstrand S, Lagerlöf J, Hedlund K, Mårtensson A (2008) Carbon routes from decomposing plant residues and living roots into soil food webs assessed with ${ }^{13} \mathrm{C}$ labelling. Soil Biology and Biochemistry 40, 2530-2539.

Evershed RP, Crossman ZM, Bull ID, Mottram H, Dungait JAJ, Maxfield PJ, Brennand EL (2006) ${ }^{13} \mathrm{C}$-Labelling of lipids to investigate microbial communities in the environment. Current Opinion in Biotechnology 17, 72-82.

Fornara DA, Tilman D (2008) Plant functional composition influences rates of soil carbon and nitrogen accumulation. Journal of Ecology 96, 314-322.

Frey SD, Six J, Elliott ET (2003) Reciprocal transfer of carbon and nitrogen by decomposer fungi at the soil-litter interface. Soil Biology and Biochemistry 35, 1001-1004.

Frostegård A, Bååth E (1996) The use of phospholipid fatty acid analysis to estimate bacterial and fungal biomass in soil. Biology and Fertility of Soils 22, 59-65.

Frostegård A, Tunlid A, Bååth E (1991) Microbial biomass measured as total lipid phosphate in soils of different organic content. Journal of Microbiol Methods 14, 151-163.

Frostegård A, Tunlid A, Bååth E (2011) Use and misuse of PLFA measurements in soils. Soil Biology and Biochemistry 43, 1621-1625. 
Garrett SD (1951) Ecological groups of soil fungi: a survey of substrate relationships. New Phytologist 50, 149-166.

Gessner MO, Swan CM, Dang CK, McKie BG, Bardgett RD, Wall DH, Hättenschwiler S (2010) Diversity meets decomposition. Trends in Ecology and Evolution 25, 372-380.

Grayston SJ, Griffith GS, Mawdsley JL, Campbell CD, Bardgett RD (2001) Accounting for variability in soil microbial communities of temperate upland grassland ecosystems. Soil Biology and Biochemistry 33, 533-551.

Harpole WS, Tilman D (2007) Grassland species loss resulting from reduced niche dimension. Nature 446, 791-793.

Hütsch BW, Augustin J, Merbach W (2002) Plant rhizodeposition-an important source for carbon turnover in soils. Journal of Plant Nutrition and Soil Science 165, 397-407.

Innes L, Hobbs PJ, Bardgett RD (2004) The impacts of individual plant species on rhizosphere microbial communities in soils of different fertility. Biology and Fertility of Soils 40, 7-13.

Isselstein J, Jeangros B, Pavlu V (2005) Agronomic aspects of biodiversity targeted management of temperate grasslands in Europe - A review. Agronomy Research 3, 139-151.

Jastrow JD, Amonette JE, Bailey VL (2007) Mechanisms controlling soil carbon turnover and their potential application for enhancing carbon sequestration. Climate Change 80, 5-23.

Jones MB, Donnelly A (2004) Carbon sequestration in temperate grassland ecosystems and the influence of management, climate and elevated $\mathrm{CO}_{2}$. New Phytologist 164, 423-439.

Kuzyakov Y, Cheng W (2001) Photosynthesis controls of rhizosphere respiration and organic matter decomposition. Soil Biology and Biochemistry 33, 1915-1925.

Liljeroth E, van Veen JA, Miller HJ (1990) Assimilate translocation to the rhizosphere of two wheat lines and subsequent utilization by rhizosphere microorganisms at two soil nitrogen concentrations. Soil Biology and Biochemistry 22, 1015-1021.

Marschner H, Kirkby EA, Cakmak I (1996) Effect of mineral nutritional status on shoot-root partitioning of photoassimilates and cycling of mineral nutrients. Journal of Experimental Botany 47, 1255-1263.

Marshall CB, McLaren JR, Turkington R (2011) Soil microbial communities resistant to changes in plant functional group composition. Soil Biology and Biochemistry 43, 78-85.

Moore JC, McCann K, De Ruiter PC (2005) Modeling trophic pathways, nutrient cycling, and dynamic stability in soils. Pedobiologia 49, 499-510.

Ngosong C, Gabriel E, Ruess L (2012) Use of the signature fatty acid 16:1w5 as a tool to determine the distribution of arbuscular mycorrhizal fungi in soil. Journal of Lipids 2012, 236807. 
Olsson PA, Baath E, Jakobsen (1997) Phosphorus effects on the mycelium and storage structures of an arbuscular mycorrhizal fungus as studied in the soil and roots by analysis of Fatty Acid signatures. Applied and environmental Microbiology 63, 3531-3538.

Nold SC, Boschker HTS, Pel R, Laanbroek HJ, (1999) Ammonium addition inhibits ${ }^{13} \mathrm{C}$-methane incorporation into methanotroph membrane lipids in a freshwater sediment. FEMS Microbiology Ecology 29 81-89.

Paterson E, Osler G, Dawson LA, Gebbing T, Sim A, Ord B (2008) Labile and recalcitrant plant fractions are utilised by distinct microbial communities in soil: Independent of the presence of roots and mycorrhizal fungi. Soil Biology and Biochemistry 40, 1103-1113.

Petersen U, Wrage N, Köhler L, Leuschner C, Isselstein J (2012) Manipulating the species composition of permanent grasslands-A new approach to biodiversity experiments. Basic and Applied Ecology 13, 1-9.

Petersen U, Wrage-Mönnig N, Isselstein J (2013) Effects of herbicide application to control sward composition in different management variants. International Journal of Biodiversity Science, Ecosystem Services and Management, 1-11.

Post WM, Kwon KC (2000) Soil carbon sequestration and land-use change: processes and potential. Global Change Biology 6, 317-327.

Potthoff M, Loftfield N, Buegger F, Wick B, John B, Joergensen RG, Flessa H (2003) The determination of $\delta^{13} \mathrm{C}$ in soil microbial biomass using fumigation-extraction. Soil Biology and Biochemistry 35, 947-954.

Rinnan R, Bååth E (2009) Differential utilization of carbon substrates by bacteria and fungi in tundra soil. Applied and Environmental Microbiology 75, 3611-3620.

Rose L, Leuschner C (2012) The diversity-productivity relationship in a permanent temperate grassland: negative diversity effect, dominant influence of management regime. Plant Ecology and Diversity 5, 265-274.

Rousk J, Bååth E (2011) Growth of saprotrophic fungi and bacteria in soil. FEMS Microbiology Ecology 78, 17-30.

Ruess L, Chamberlain PM (2010) The fat that matters: Soil food web analysis using fatty acids and their carbon stable isotope signature. Soil Biology and Biochemistry 42, 1898-1910.

Sala O, Chapin F, Armesto J J, Berlow E, Bloomfield J, Dirzo R, Huber-Sanwald E, Huenneke LF, Jackson RB, Kinzig A, Leemans R, Lodge DM, Mooney HA, Oesterheld M, Poff NL, Sykes MT, Walker BH, Walker M, Wall DH (2000) Global biodiversity scenarios for the year 2100. Science 287:1770-1774.

Son CL, Smith SE (1988) Mycorrhizal growth responses: interactions between photon irradiance and phosphorus nutrition. New Phytologist 108, 305-314. 
Suding KN, Collins SL, Gough L, Clark C, Cleland EE, Gross KL, Milchunas DG, Pennings S (2005) Functional- and abundance-based mechanisms explain diversity loss due to $\mathrm{N}$ fertilization. Proceedings of the National Academy of Sciences of the United States of America 102, 4387-4392.

Vance ED, Brookes PC, Jenkinson DS (1987) An extraction method for measuring soil microbial biomass C. Soil Biology and Biochemistry 19, 703-707.

Van Hees PAW, Jones DL, Finlay R, Godbold DL, Lundström US (2005) The carbon we do not see-the impact of low molecular weight compounds on carbon dynamics and respiration in forest soils: a review. Soil Biology and Biochemistry 37, 1-13.

Veresoglou SD, Mamolos AP, Thornton B, Voulgari OK, Sen R, Veresoglou DS (2011) Mediumterm fertilization of grassland plant communities masks plant species-linked effects on soil microbial community structure. Plant and Soil 344, 187-196.

Vitousek PM, Mooney HA, Lubchenco J, Melillo JM (1997) Human domination of Earth's ecosystems. Science 277, 494-499.

Wu J, Joergensen RG, Pommerening B, Chaussod R, Brookes PC (1990) Measurement of soil microbial biomass $C$ by fumigation-extraction - an automated procedure. Soil Biology and Biochemistry 22, 1167-1169.

Yao H, Thornton B, Paterson E (2012) Incorporation of ${ }^{13} \mathrm{C}$-labelled rice rhizodeposition carbon into soil microbial communities under different water status. Soil Biology and Biochemistry $53,72-77$.

Zeller V, Bardgett RD, Tappeiner U (2001) Site and management effects on soil microbial properties of subalpine meadows: a study of land abandonment along a north-south gradient in the European Alps. Soil Biology and Biochemistry 33, 639-649.

Zhang H, Ding W, Yu H, He X (2013) Carbon uptake by a microbial community during 30-day treatment with ${ }^{13} \mathrm{C}$-glucose of a sandy loam soil fertilized for 20 years with NPK or compost as determined by a GC-C-IRMS analysis of phospholipid fatty acids. Soil Biology and Biochemistry 57, 228-236. 


\title{
Chapter 4
}

\section{Fertilizer addition lessens the flux of microbial carbon to higher trophic levels in soil food webs of grassland}

\author{
Kathleen Lemanski \& Stefan Scheu
}
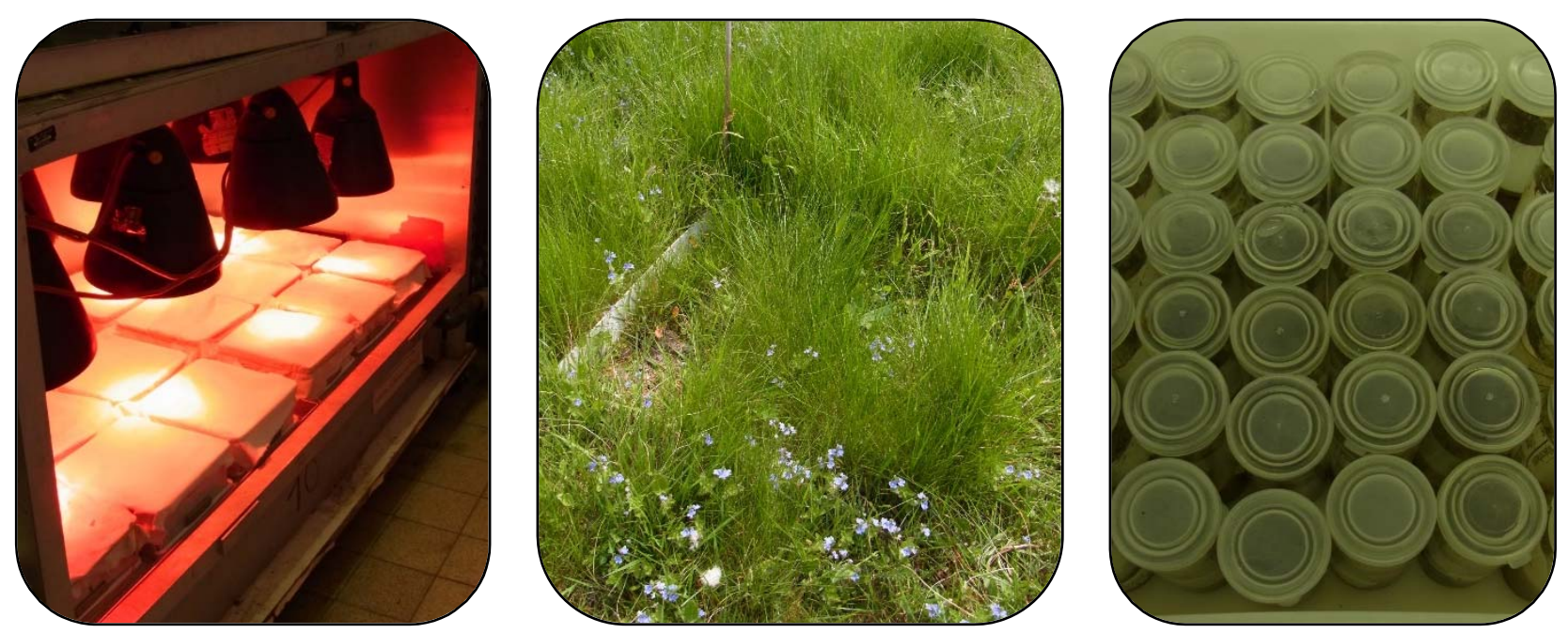

Published in: Lemanski K, Scheu S (2014) Fertilizer addition lessens the flux of microbial carbon to higher trophic levels in soil food webs of grassland. Oecologia 176, 487-496. 


\section{Abstract}

Roots and root derived carbon (C) compounds are increasingly recognised to form important resources for soil animal food webs. We used ${ }^{13} \mathrm{C}$ labelled glucose as model $\mathrm{C}$ compound representing root exudates to follow the incorporation of root derived $\mathrm{C}$ into the soil animal food web of temperate grassland over a period of 52 weeks. We investigated variations in glucose $\mathrm{C}$ incorporation with fertilizer addition and sward composition, i.e. variations in plant functional groups. The approach allowed differentiating trophic chains based on primary decomposers feeding on litter and phytophagous species feeding on roots (i.e., not incorporating glucose C) from those based on secondary decomposers feeding on microorganisms (thereby assimilating glucose C). Each of the studied soil animal species incorporated glucose $\mathrm{C}$, indicating that the majority of grassland soil animal species relies on microorganisms as food resources with microorganisms being fuelled by root exudates. However, incorporation of glucose $\mathrm{C}$ into soil animal species varied markedly with species identity suggesting that detritivorous microarthropods complement each other in channelling microbial $\mathrm{C}$ through soil food webs. Fertilizer addition markedly reduced the concentration of glucose $\mathrm{C}$ in most soil animal species as well as absolute transfer of glucose $\mathrm{C}$ into oribatid mites as major secondary decomposers. The results suggest that fertilizer addition shifts the basis of the decomposer food web towards the use of unlabelled resources, presumably roots, i.e., towards a herbivore system, thereby lessening the link between microorganisms and microbial grazers and hampering the propagation of microbial $\mathrm{C}$ to higher trophic levels.

\section{Keywords}

Soil arthropods, trophic interactions, stable isotopes, rhizodeposition, root exudates 


\section{Introduction}

In Europe grasslands are among the most important agricultural systems, covering over $30 \%$ of the arable land (Isselstein et al. 2005). Management practices of arable systems including grasslands are receiving increased interest in the last years as they affect major ecosystem services, such as carbon (C) sequestration and storage in soil organic matter (Post and Kwon 2000; Jones and Donnelly 2004). Further, changes in land use are among the most important drivers for the present and expected global decline in biodiversity (Vitousek et al. 1997; Sala et al. 2000). In particular increased fertilizer input into arable systems threatens biodiversity and ecosystem functioning (Suding et al. 2005; Harpole and Tilman 2007) despite arthropod abundance often is increased in fertilized grasslands (Siemann 1998; Haddad et al. 2000). In contrast to the aboveground system, effects of fertilizer addition on the belowground system and on the flux of $\mathrm{C}$ into decomposer food webs are poorly studied (Eisenhauer et al. 2012; Reid et al. 2012). Knowledge on the effect of fertilizers on the belowground system is important as fertilizer addition affects both the composition of grassland systems and the investment of plants into belowground components, such as roots and root exudates (Högberg et al. 2010; Eisenhauer et al. 2012).

Belowground food-webs rely on $\mathrm{C}$ produced by plants. Aboveground $\mathrm{C}$ resources enter the belowground system either via root derived compounds synthesized from currently assimilated $\mathrm{C}$ by plants or via plant litter, i.e. dead plant residues. The importance of root derived resources has long been underestimated, however, recent studies suggest that the majority of soil animals rely on C derived from live roots (Albers et al. 2006; Ostle et al. 2007; Pollierer et al. 2007; Pollierer et al. 2012). Live root tissue may be consumed directly by herbivores but also provide an array of other root derived resources including exudates consisting of low molecular weight compounds, such as sugars, organic acids and amino acids that are easily available to soil organisms (Hodge et al. 1996). Photosynthate C inputs via roots are affected by a number of factors, such as nitrogen availability (Hodge et al. 1996), plant species composition (Grayston et al. 1998) and aboveground herbivory (Holland et al. 1996). However, knowledge to what extend these factors modify the provision and incorporation of root derived $\mathrm{C}$ into soil animal food webs is lacking.

To follow the channelling of $C$ through soil food webs requires knowledge on the trophic structure of and food relationships between soil biota. Soil food webs comprise a number of 
trophic levels including primary decomposers, secondary decomposers and predators (Scheu and Falca 2000). Primary decomposers predominantly rely on plant litter and plant derived dead organic matter as food resources, whereas secondary decomposers predominantly feed on microorganisms and microbial residues (Scheu and Falca 2000; Pollierer et al. 2009).

However, rather than comprising distinct trophic levels species are forming a gradient from those predominantly feeding on litter to those predominantly feeding on microorganisms (Scheu and Falca 2000; Eissfeller et al. 2013). Predators have been assumed to predominantly feed on secondary decomposers thereby channelling $C$ to higher trophic levels via microorganisms rather than via detritivores relying on litter C (Scheu 2002), but the relative importance of these two pathways to the nutrition of higher trophic levels is little understood (Ferlian et al. 2012; Eitzinger et al. 2013; Klarner et al. 2013). Natural variations in the ratio between stable isotopes of $\mathrm{C}\left({ }^{13} \mathrm{C} /{ }^{12} \mathrm{C}\right)$ and nitrogen $\left({ }^{15} \mathrm{~N} /{ }^{14} \mathrm{~N}\right)$ have been shown to be a powerful tool for analysing the trophic structure of soil animal communities (Scheu and Falca 2000; Tiunov 2007). Further, isotope tracers enriched in ${ }^{13} \mathrm{C}$ and ${ }^{15} \mathrm{~N}$ allow following $\mathrm{C}$ and nitrogen fluxes through belowground systems including soil animal communities (Ostle et al. 2007; Pollierer et al. 2007; Strickland et al. 2012). Glucose is a common component of root exudates (Hodge et al. 1996) and in the present study we used ${ }^{13} \mathrm{C}$ labelled glucose as model compound to track the incorporation of $\mathrm{C}$ in root exudates into belowground food webs. Using glucose as model compound Strickland et al. (2012) showed labile C compounds to propagate into multiple belowground $\mathrm{C}$ pools, including higher level predators such as mesostigmatid mites within three days.

We traced the incorporation of glucose $\mathrm{C}$ into major components of soil animal food webs of temperate grassland for a period of one year and investigated variations in glucose $\mathrm{C}$ incorporation with fertilizer addition and sward composition, i.e. variations in plant functional groups. Tracing the incorporation of glucose $\mathrm{C}$ into the soil animal food web we aimed at (1) identifying root exudate associated trophic chains and their dynamics, allowing to differentiate between species feeding mainly on litter and plant tissue and those feeding on microorganisms, (2) investigating the influence of fertilizer addition and sward composition on the incorporation of root exudate $\mathrm{C}$ into the soil animal food web of grassland, and (3) testing if changes in the abundance of dicotyledonous plants, especially legumes, alters the incorporation of glucose C into soil invertebrates is lessened by fertilizer application. 


\section{Material and methods}

\section{Study site and experimental design}

The experiment was carried out within the framework of the 'GRASSMAN' (Grassland Management) experiment investigating consequences of grassland management intensity and sward composition for grassland functionality (Petersen et al. 2012). The study site is located in the Solling, a mountain range in northern Germany $\left(51^{\circ} 44^{\prime} \mathrm{N}, 9^{\circ} 23^{\prime} \mathrm{E} ; 490 \mathrm{~m}\right.$ a.s.l.). Mean annual temperature is $6.9^{\circ} \mathrm{C}$ and mean annual precipitation is $1028 \mathrm{~mm}$ (average of 1969-1990; German Weather Service). Prior to the experiment the site was used for cattle grazing. Vegetation is classified as nutrient poor montane mesic Lolio-Cynosuretum. The soil is characterized as Haplic Cambisol.

The experiment was set up in 2008 in a full factorial design comprising the factors sward composition (three levels differing in the proportion of monocotyledons and dicotyledons) and fertilization (two levels). Each treatment level was replicated six times. For setting up the experiment the site was mown and plots of a size of $15 \times 15 \mathrm{~m}$ were established. Sward types of different plant composition were established in 2009 by applying herbicides targeting either dicotyledons (Starane, Dow AgroSciences, Munich, Germany; active ingredients fluroxypyr and triclopyr, and Duplosan KV, Du Pont de Nemours, Neu-Isenburg, Germany; active ingredient methylchlorophenoxy propinoic acid; both 3 I ha-1) or monocotyledons (Select 240 EC, Stähler Int., Stade, Germany; active ingredient clethodim; $0.5 \mathrm{I} \mathrm{ha-1}$ ) resulting in sward types reduced in dicotyledons (DR) or monocotyledons (MR); plots not treated with herbicides served as control (Ctr). In 2011 the proportion of plant functional groups were 75.0, 68.1 and $71.7 \%$ for grasses, 24.6, 29.9 and 26.9\% for herbs, and 0.5, 2.0 and 1.4\% for legumes in DR, MR and Ctr treatments, respectively (T. From, unpubl. data). Fertilization treatments included NPK fertilizer addition (+NPK) and no fertilizer addition (-NPK). Fertilization started in 2008 with the addition of Nand was continued in 2009 until 2012 by the addition of $\mathrm{N}$ split into two equal applications per year while the combined $\mathrm{P}$ and $\mathrm{K}$ fertilizer was applied once per year, resulting in an application of $180-30-100 \mathrm{~kg} \mathrm{N-P-K} \mathrm{ha-1} \mathrm{y}^{-1}$ on respective plots. Fertilizer application significantly increased aboveground biomass production (Rose et al. 2012). All plots were mown annually in July. More details on the study site and design of the experiment are given in Petersen et al. (2012). 


\section{${ }^{13} \mathrm{C}$ labelling and analysis}

In May $20110.5 \mathrm{~g}{ }^{13} \mathrm{C}$ labelled glucose $\left(99\right.$ atom $\%{ }^{13} \mathrm{C}$ ) dissolved in $500 \mathrm{ml}$ water was applied to an enclosed area of $0.5 \times 0.5 \mathrm{~m}$ at each plot. In each of the individual 36 plots soil samples were taken after two weeks (June 2011), six weeks (July 2011), 18 weeks (October 2011) and 52 weeks (May 2012). For each sample approximately $0.2 \times 0.2 \mathrm{~m}$ of soil to a depth of $5 \mathrm{~cm}$ was taken with a spade. Grass shoots were cut and the arthropods were extracted using a modified heat extractor (Kempson et al. 1963). Arthropods were transferred into collection vials and stored in $70 \%$ ethanol until species determination and ${ }^{13} \mathrm{C}$ analysis. Control samples were taken the year before (2010) for analysing natural variations in stable isotope ratios.

The most abundant species of oribatid mites [Liebstadia similis (Michael), Eupelops plicatus (C.L. Koch) and Platynothrus peltifer (C.L. Koch)], gamasid mites [Pachylaelaps laeuchlii (Schweizer)], uropodid mites [Uropoda minima (Kramer)] and collembolans [Protaphorura armata (Tullberg), Lepidocyrtus cyaneus (Tullberg) and Lepidocyrtus lanuginosus (Gmelin)] were taken for stable isotope analysis. Animals were transferred into tin capsules and dried at $60^{\circ} \mathrm{C}$ for $24 \mathrm{~h}$ prior to measurement of stable isotopes. For small species up to 60 individuals had to be pooled to obtain enough material for the analyses, and if necessary, individuals from replicates were pooled. Stable isotope ratios and C content were determined using a coupled system of an elemental analyser (NA 1100, CE Instruments or Euro EA 3000, EuroVector S.p.A.; Milan, Italy) and a mass spectrometer (Delta Plus, Finnigan MAT or Delta V Plus, Thermo Electron; Bremen, Germany) coupled via an interface (Conflo III, Finnigan MAT or Conflo IV, Thermo Electron; Bremen, Germany) (Werner et al. 1999). More details on stable isotope analysis and the constraints of the technique in respect to the amount of tissue necessary for the analysis are reported in Langel and Dyckmans (2014).

C isotope ratios were calculated using the $\delta$ notation (\%o) relative to Vienna Pee Dee Belemnite standard (V-PDB) calculated as $\delta^{13} \mathrm{C}=\left(\frac{\mathrm{R}_{\text {sample }}}{\mathrm{R}_{\mathrm{V} \text {-PDB }}}-1\right) \times 1000$, where $\mathrm{R}_{\text {sample }}$ and $\mathrm{R}_{\mathrm{V} \text {-PDB }}$ are the ${ }^{13} \mathrm{C} /{ }^{12} \mathrm{C}$ ratios of the sample and V-PDB (0.0111802), respectively. Concentration of glucose $\mathrm{C}$ in soil animal species was measured as shift in $\delta^{13} \mathrm{C}$ signatures calculated as $\Delta^{13} C=\delta^{13} C_{\text {labelled }}-\delta^{13} C_{\text {control }}$, where $\delta^{13} C_{\text {labelled }}$ is the animal signature in glucose addition plots and $\delta^{13} \mathrm{C}_{\text {control }}$ is the animal signature in control plots without glucose addition. The amount of 
excess ${ }^{13} \mathrm{C}$ in animal species was calculated as ${ }^{13} C_{\text {animal }}=C_{\text {animal }} \times A P E$, where $C_{\text {animal }}$ is the amount of $C$ in the respective species and APE is the atom percent excess calculated as

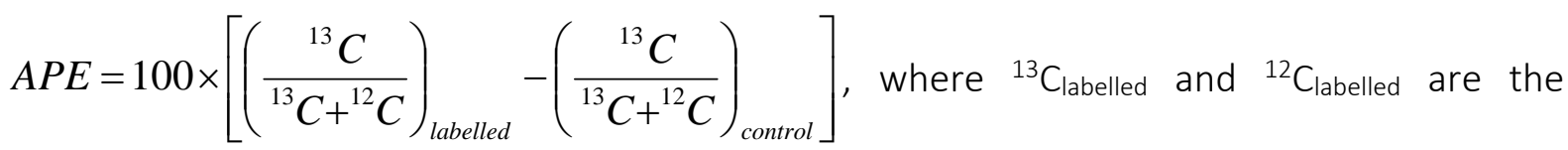
abundance of $\mathrm{C}$ isotopes in the labelled and ${ }^{13} \mathrm{C}_{\text {control }}$ and ${ }^{12} \mathrm{C}_{\text {control }}$ are the respective values in unlabelled samples. The amount of $\mathrm{C}$ in the respective species [biomass; $\mathrm{mg} \mathrm{C} \mathrm{m}^{-2}$ ] was calculated from the average individual body mass (determined from samples for stable isotope analysis), the abundance (determined by heat extraction) and the $\mathrm{C}$ concentration (measured by elemental analysis; see above).

\section{Statistical analysis}

As some samples had to be pooled thus reducing the number of replicates, it was not possible to calculated all main effects and interactions for all species in one analysis. As sward composition did not significantly affect animal abundance and the incorporation of glucose $\mathrm{C}$ into any of the species data were pooled for sward. Total amount of $\mathrm{C}$ and ${ }^{13} \mathrm{C}$ in animal species, and animal $\Delta^{13} \mathrm{C}$ signatures were analysed by repeated measures GLM including species as fixed factor and time as repeated factor. Further, total $\mathrm{C},{ }^{13} \mathrm{C}$ and $\Delta^{13} \mathrm{C}$ signatures of individual species were analysed by repeated measures ANOVA with time as repeated factor. Statistical analyses were performed using SAS 9.2 (SAS Institute, Cary, NC, USA).

\section{Results}

\section{Natural variations in stable isotope ratios}

Plant shoot $\delta^{13} \mathrm{C}$ and $\delta^{15} \mathrm{~N}$ values were on average $-27.60 \pm 0.43 \%$ (SD) and $0.50 \pm 0.68 \%$, respectively. In soil animals $\delta^{13} \mathrm{C}$ values ranged from $-26.97 \pm 0.12 \%$ in E. plicatus to $-24.71 \pm$ $0.11 \%$ in $U$. minima and $\delta^{15} \mathrm{~N}$ values from $2.02 \pm 1.15 \%$ in $P$. peltifer to $8.81 \pm 0.59 \%$ in $U$. minima (Fig. 1). 


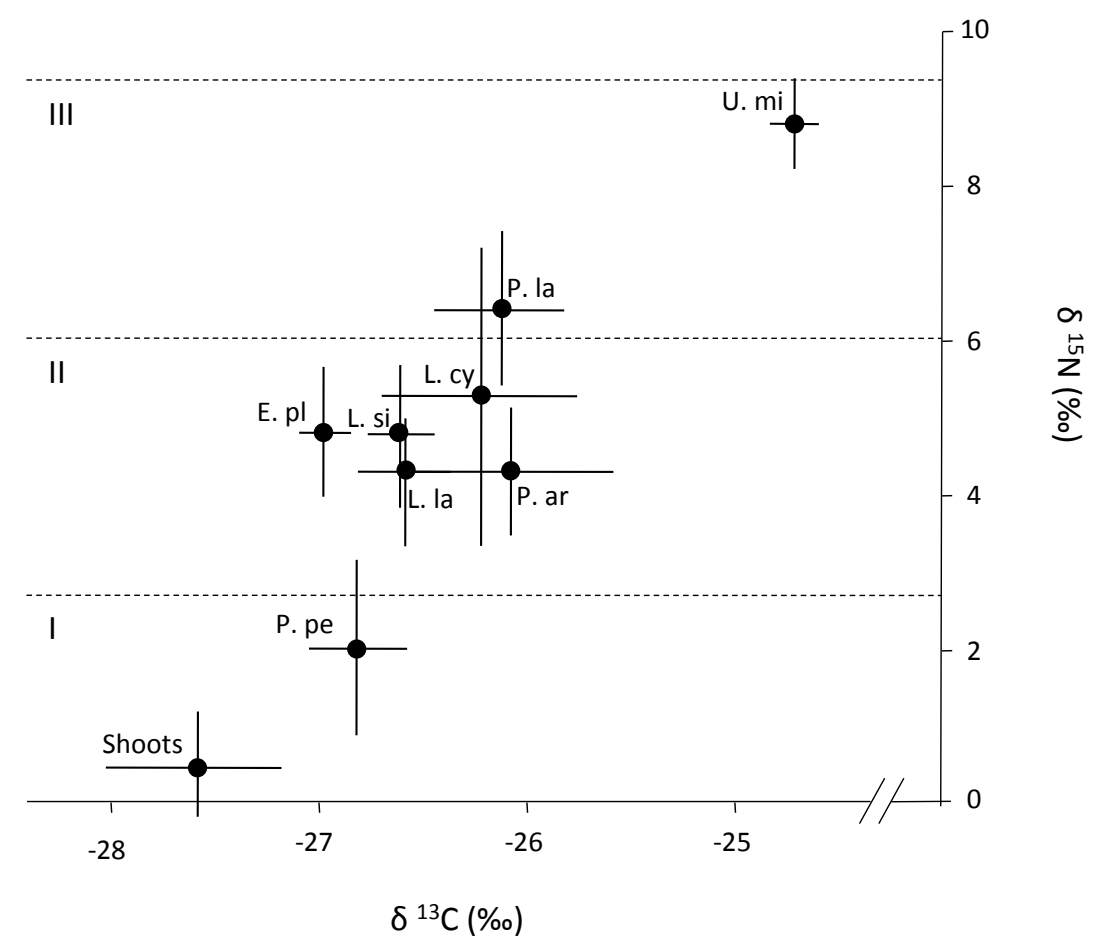

Figure 1 Natural variations in stable isotope signatures $\left(\delta^{13} \mathrm{C}\right.$ and $\left.\delta^{15} \mathrm{~N}\right)$ of plant shoots and animal species. P.ar: Protaphorura armata, L.cy: Lepidocyrtus cyaneus, L.la: Lepidocyrtus lanuginosus, L.si: Liebstadia similis, E.pl: Eupelops plicatus, P.pe: Platynothrus peltifer, P.la: Pachylaelaps laeuchlii and U.mi: Uropoda minima. Dashed horizontal lines represent estimated trophic level boundaries based on the mean $\delta^{15} \mathrm{~N}$ signature of shoots, with an enrichment of $0.5 \%$ for primary decomposers $(\mathrm{I})$ and $3.4 \%$ for secondary decomposer (II) and predators (III) (Post 2002; Vanderklift and Ponsard 2003). Samples were taken in 2010, one year before starting the labelling; means \pm SD.

\section{Biomass of soil animals}

Animal biomass measured as amount of $C$ in soil animal species varied between $0.30 \mathrm{mg} \mathrm{C} \mathrm{m}{ }^{-2}$ for both U. minima (non-fertilized treatments 18 weeks after glucose addition) and L. lanuginosus (fertilized treatments 2 weeks after glucose addition), and 6.2 and $6.4 \mathrm{mg} \mathrm{C} \mathrm{m}{ }^{-2}$ for $P$. armata and $P$. peltifer both in non-fertilized treatments 18 and 52 weeks after glucose addition, respectively (Table 1, and Fig. 2). As indicated by repeated GLM, total $\mathrm{C}$ in soil animals increased with time $\left(F_{3,150}=5.83, P<0.001\right)$, and varied between species and fertilizer addition (species $x$ fertilizer interaction; $F_{7,50}=3.69, P=0.003$ ). Separate ANOVAs for each species indicated that the increase with time was mainly due to L. lanuginosus and E. plicatus, and the significant interaction between species and fertilizer was mainly due to increased animal $\mathrm{C}$ in 
non-fertilized treatments in P. peltifer and L. similis (Table 1 and Fig. 2). Generally, the amount of $\mathrm{C}$ in soil animal species did not vary significantly with sward composition.

\section{Incorporation of ${ }^{13} \mathrm{C}$ into soil animals}

Each of the studied soil animal species incorporated glucose C, however, incorporation markedly differed between species. Glucose $\mathrm{C}$ concentrations, measured as $\Delta^{13} \mathrm{C}$ signatures, reached a maximum of $72 \%$ in L. lanuginosus in non-fertilized treatments after 2 weeks. After 52 weeks enrichment in ${ }^{13} \mathrm{C}$ in both Lepidocyrtus species was negligible whereas $\Delta^{13} \mathrm{C}$ values of P. peltifer still were high (28\%o). The amount of glucose C incorporated into soil animals was high in the oribatid mites $P$. peltifer and L. similis with an average of 214 and $73 \mu \mathrm{g}^{13} \mathrm{C} \mathrm{m}^{-2}$ in non-fertilized treatments, respectively, whereas it was low in the uropodid mite U. minima and the collembolan L. lanuginosus with an average of 4 (non-fertilized treatments) and $5 \mu \mathrm{g}^{13} \mathrm{C} \mathrm{m}^{-2}$ (fertilized treatments), respectively (Fig. 2).

As indicated by GLM, concentrations of glucose $\mathrm{C}$ measured as $\Delta^{13} \mathrm{C}$ signatures significantly varied between species, and with time and fertilizer addition (time $\mathrm{x}$ species $\mathrm{x}$ fertilizer interaction; $\left.F_{21,150}=2.75, P=0.0003\right)$. Generally, glucose $C$ concentrations in soil animals in non-fertilized treatments exceeded those in fertilized treatments and this was most pronounced early in the experiment. Overall, concentrations of glucose $\mathrm{C}$ into soil animals declined with time. The amount of glucose $\mathrm{C}$ incorporated into soil animals followed a similar pattern than glucose $\mathrm{C}$ concentrations in soil animals and varied between species, time and fertilizer addition (time $x$ species $x$ fertilizer interaction; $F_{21,150}=7.23, P<0.0001$ ).

In general, concentrations of glucose $\mathrm{C}$ in soil animals in non-fertilized exceed those in fertilized treatments, however, this was not significant for the oribatid mite E. plicatus, the uropodid mite U. minima and only in trend for the collembolan L. lanuginosus (Table 2). The amount of glucose $\mathrm{C}$ incorporated into soil animal species followed a similar pattern but the effect was generally less pronounced compared to concentrations of glucose $\mathrm{C}$ and only significant for the oribatid mites L. similis and P. peltifer (Table 3). Separate ANOVAs for individual species suggest that both concentrations and amount of glucose $\mathrm{C}$ incorporated into soil animals varied significantly or in trend with time and fertilizer addition for the collembolans L. lanuginosus and L. cyaneus, and the oribatid mite P. peltifer (Table 2 and 3). In the two Lepidocyrtus species 
concentrations of glucose $\mathrm{C}$ in non-fertilized exceeded that in fertilized treatments after 2 weeks, but the differences diminished later in the experiment. In contrast, concentrations of glucose $C$ in $P$. peltifer at the first sampling dates was similar in fertilized and non-fertilized treatments but significantly higher in non-fertilized treatments at later sampling dates (Fig. 2). Changes in concentrations of glucose $C$ in soil animal species with time were similar in the collembolans L. lanuginosus and L. cyaneus, and the oribatid mites E. plicatus and L. similis, whereas for the amount of glucose $C$ this was only true for L. lanuginosus, L. cyaneus and $E$. plicatus. Incorporation of glucose $\mathrm{C}$ into these species was at a maximum at the first sampling date 2 weeks after labelling and decreased thereafter. Glucose C concentrations were highest in L. lanuginosus after 2 weeks ( $\Delta^{13} \mathrm{C}$ of $59 \%$ ), but then declined rapidly and vanished after 18 weeks. In contrast, in the gamasid mite P. laeuchlii concentrations of glucose $C$ were much lower (maximum $\Delta^{13} \mathrm{C}$ of $6 \%$ after 2 weeks), but also declined slower reaching $4 \%$ after 52 weeks. In contrast to L. lanuginosus, L. cyaneus and E. plicatus, concentrations and amounts of glucose $C$ in $P$. peltifer, $P$. armata and U. minima were highest later in the experiment and for the amount of glucose $C$ this also applied for L. similis and P. laeuchlii. Generally, neither concentrations nor amounts of glucose $\mathrm{C}$ in soil animals varied with sward composition. 
Table 1. Repeated measures ANOVA table of F- and P-values on the effect of the addition of NPK fertilizer and sampling date on the biomass of soil animal species $\left(\mathrm{g} \mathrm{C} \mathrm{m}^{-2}\right)$. The two degree of freedom (df) values are for effect and error. Significant effects are given in bold. For full species names see Fig. 1.

\begin{tabular}{|c|c|c|c|c|c|c|c|c|c|}
\hline \multirow[b]{2}{*}{ Species } & \multicolumn{3}{|c|}{ Time } & \multicolumn{3}{|c|}{ Fertilizer } & \multicolumn{3}{|c|}{ Time x Fertilizer } \\
\hline & $\mathrm{df}$ & $F$ & $P$ & $\mathrm{df}$ & $F$ & $P$ & $\mathrm{df}$ & $F$ & $P$ \\
\hline L. lanuginosus & 3,18 & 4.89 & 0.012 & 1,4 & 0.07 & 0.798 & 3,18 & 0.57 & 0.640 \\
\hline L. cyaneus & 3,12 & 1.87 & 0.189 & 1,6 & 0.16 & 0.708 & 3,12 & 0.37 & 0.775 \\
\hline P. armata & 3,24 & 2.13 & 0.129 & 1,8 & 0.97 & 0.354 & 3,24 & 0.17 & 0.902 \\
\hline E. plicatus & 3,18 & 3.35 & 0.049 & 1,6 & 2.08 & 0.200 & 3,18 & 0.04 & 0.741 \\
\hline L. similis & 3,24 & 1.60 & 0.216 & 1,8 & 9.60 & 0.015 & 3,24 & 0.17 & 0.914 \\
\hline P. peltifer & 3,24 & 0.55 & 0.652 & 1,8 & 8.98 & 0.017 & 3,24 & 0.59 & 0.629 \\
\hline P. laucheii & 3,18 & 3.16 & 0.050 & 1,6 & 2.88 & 0.141 & 3,18 & 0.82 & 0.500 \\
\hline U. minima & 3,12 & 0.27 & 0.765 & 1,4 & 3.57 & 0.132 & 3,12 & 0.53 & 0.604 \\
\hline
\end{tabular}

Table 2. Repeated measures ANOVA table of $\mathrm{F}$ - and P-values on the effect of the addition of NPK fertilizer and sampling date on $\Delta^{13} \mathrm{C}$ signatures in soil animals. The two degree of freedom (df) values are for effect and error. Significant effects are given in bold. For full species names see Fig. 1.

\begin{tabular}{|c|c|c|c|c|c|c|c|c|c|}
\hline \multirow[b]{2}{*}{ Species } & \multicolumn{3}{|c|}{ Time } & \multicolumn{3}{|c|}{ Fertilizer } & \multicolumn{3}{|c|}{ Time $x$ Fertilizer } \\
\hline & df & $F$ & $P$ & $\mathrm{df}$ & $F$ & $P$ & $\mathrm{df}$ & $F$ & $P$ \\
\hline L. lanuginosus & 3,18 & 67.87 & $<0.001$ & 1,4 & 4.29 & 0.084 & 3,18 & 3.41 & 0.101 \\
\hline L. cyaneus & 3,12 & 124.62 & $<0.001$ & 1,6 & 16.51 & 0.015 & 3,12 & 7.16 & 0.030 \\
\hline P. armata & 3,24 & 34.63 & $<0.001$ & 1,8 & 24.88 & 0.001 & 3,24 & 2.21 & 0.113 \\
\hline E. plicatus & 3,18 & 17.30 & 0.003 & 1,6 & 1.49 & 0.269 & 3,18 & 1.00 & 0.370 \\
\hline L. similis & 3,24 & 50.91 & $<0.001$ & 1,8 & 11.78 & 0.009 & 3,24 & 2.85 & 0.107 \\
\hline P. peltifer & 3,24 & 4.99 & 0.008 & 1,8 & 7.91 & 0.023 & 3,24 & 2.53 & 0.081 \\
\hline P. laucheii & 3,18 & 3.08 & 0.054 & 1,6 & 15.48 & 0.008 & 3,18 & 1.51 & 0.247 \\
\hline U. minima & 3,12 & 7.57 & 0.015 & 1,4 & 2.24 & 0.209 & 3,12 & 1.25 & 0.338 \\
\hline
\end{tabular}


Table 3. Repeated measures ANOVA table of F- and P-values on the effect of the addition of NPK fertilizer and sampling date on the amount of ${ }^{13} \mathrm{C}$ in soil animal populations. The two degree of freedom (df) values are for effect and error. Significant effects are given in bold. For full species names see Fig. 1.

\begin{tabular}{|c|c|c|c|c|c|c|c|c|c|}
\hline \multirow[b]{2}{*}{ Species } & \multicolumn{3}{|c|}{ Time } & \multicolumn{3}{|c|}{ Fertilizer } & \multicolumn{3}{|c|}{ Time $x$ Fertilizer } \\
\hline & $\mathrm{df}$ & $F$ & $P$ & df & $F$ & $P$ & df & $F$ & $P$ \\
\hline L. lanuginosus & 3,18 & 33.74 & 0.000 & 1,4 & 1.76 & 0.233 & 3,18 & 4.33 & 0.056 \\
\hline L. cyaneus & 3,12 & 19.40 & 0.002 & 1,6 & 0.20 & 0.679 & 3,12 & 0.28 & 0.725 \\
\hline P. armata & 3,24 & 27.97 & $<0.001$ & 1.8 & 0.32 & 0.588 & 3,24 & 1.93 & 0.165 \\
\hline E. plicatus & 3,18 & 8.83 & 0.002 & 1,6 & 1.70 & 0.240 & 3,18 & 0.41 & 0.707 \\
\hline L. similis & 3,24 & 59.32 & $<0.001$ & 1,8 & 5,51 & 0.047 & 3,24 & 0.66 & 0.515 \\
\hline P. peltifer & 3,24 & 14.98 & 0.002 & 1,8 & 8.15 & 0.021 & 3,24 & 17.89 & 0.001 \\
\hline P. laucheii & 3,18 & 77.49 & $<0.001$ & 1,6 & 0.06 & 0.820 & 3,18 & 2.41 & 0.101 \\
\hline U. minima & 3,12 & 5.68 & 0.012 & 1,4 & 1.01 & 0.373 & 3,12 & 2.52 & 0.107 \\
\hline
\end{tabular}




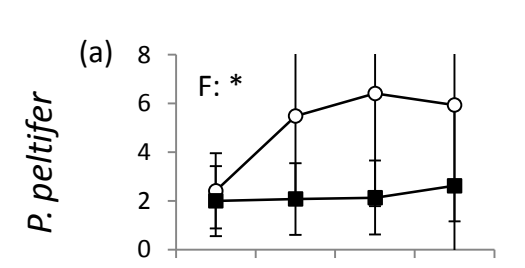

(b) 80
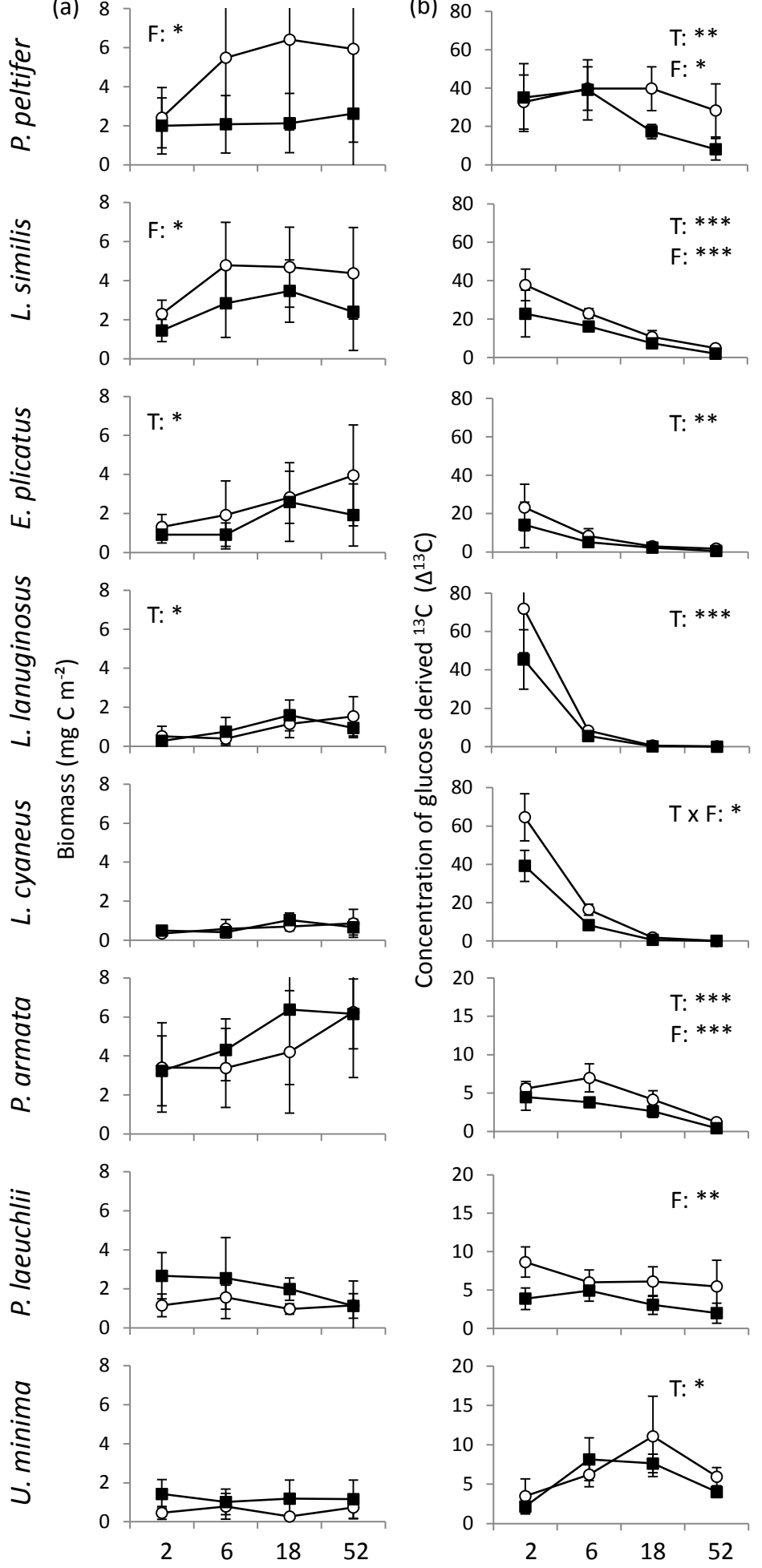
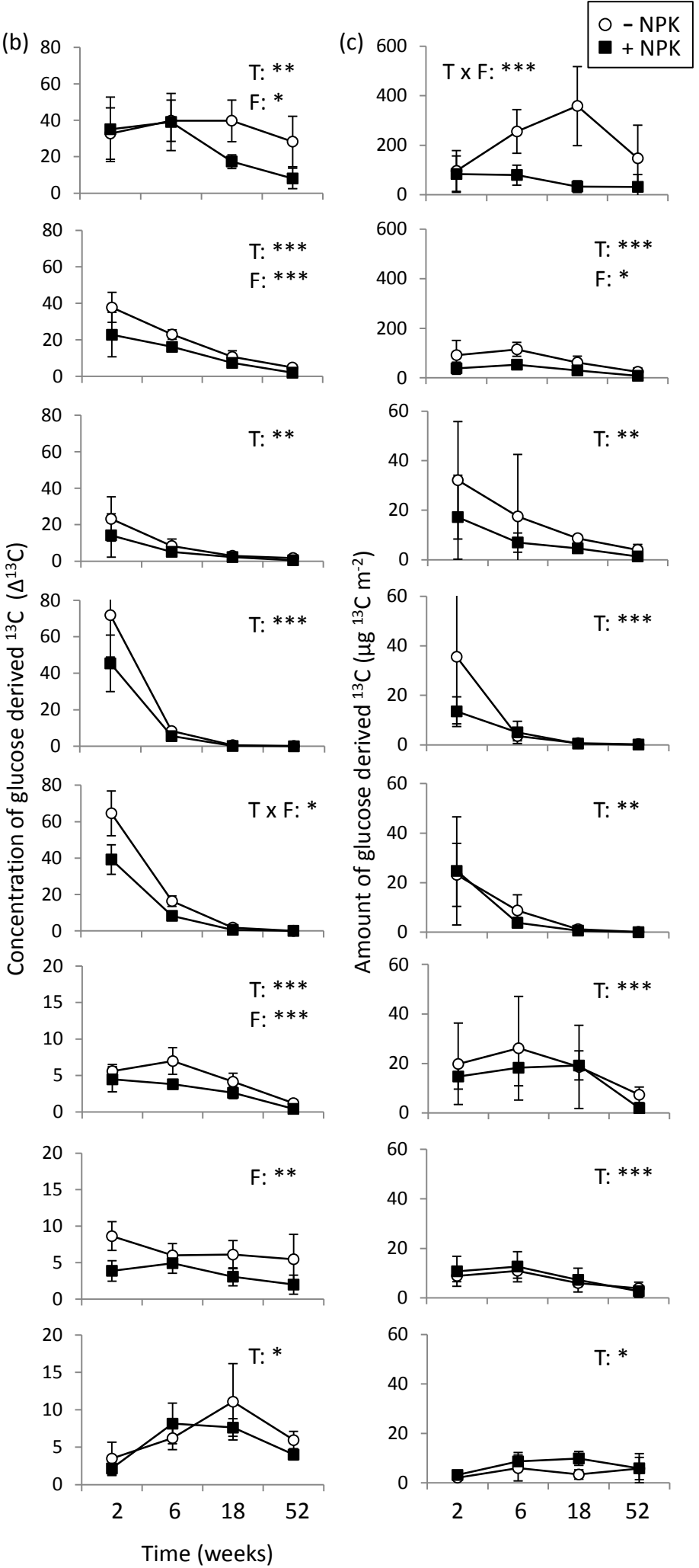

Figure 2 Changes in (a) animal biomass as measured by the amount of $C$ in animal populations, (b) concentrations of glucose derived ${ }^{13} \mathrm{C}$ in soil animal species $\left({ }^{13} \mathrm{C}\right.$ signatures), and (c) the amount of ${ }^{13} \mathrm{C}$ of added glucose in soil animal species (see Methods for calculation) with time (weeks after ${ }^{13} \mathrm{C}$ glucose addition) and due to the addition of NPK fertilizer. T: Time, F: Fertilizer; ${ }^{* * *} P<0.001 * * P<0.01 * P<$ 0.05 ; means \pm SD. For full species names see Fig. 1 . Species are ordered according to the amount of glucose derived ${ }^{13} \mathrm{C}$ incorporated. Note different scales in concentration of glucose derived ${ }^{13} \mathrm{C}\left(\Delta^{13} \mathrm{C}\right)$ and amount of glucose derived ${ }^{13} \mathrm{C}$ in soil animal species. 


\section{Discussion}

We traced the incorporation of glucose $\mathrm{C}$, mimicking root exudates, into the soil animal food web of grassland. Thereby, we identified trophic chains related to root exudates and evaluated the influence of management regime (i.e., fertilizer addition and sward composition) on flux of $\mathrm{C}$ into the belowground systems. We aimed at differentiating species feeding as primary decomposer on litter or as phytophagous species feeding on roots (i.e., not incorporating glucose C) from those functioning as secondary decomposers feeding on microorganisms (assimilating glucose $\mathrm{C}$ ). Each of the examined animal species was enriched in ${ }^{13} \mathrm{C}$, suggesting that virtually all dominant species to a certain extent function as secondary decomposers and rely on root exudates. However, there were strong differences between species in the extent they incorporated glucose $\mathrm{C}$, and the incorporation patterns varied with time and land use management, i.e. fertilization.

\section{Variation in incorporation of glucose $\mathrm{C}$ between species}

Natural abundances in stable isotope ratios suggested the majority of species to function as secondary decomposers feeding on microorganisms. Conform to this positioning each of the species studied incorporated glucose C, but incorporation markedly varied between species. Following the incorporation of glucose $\mathrm{C}$ into soil animals therefore allowed refining the trophic positioning based on natural variations in stable isotope ratios. Concentrations of glucose $\mathrm{C}$ were at a maximum in two Lepidocyrtus species indicating that these collembolan species are closely associated with the root exudate based energy channel. The three oribatid mite species had intermediate positions with concentrations of glucose $C$ in the animals increasing in the order E. plicatus $<L$. similis $<P$. peltifer, suggesting that their association to the root exudate based channel increases in this order but that they also include litter based resources. Recent studies described E. plicatus and P. peltifer either as primary decomposers (Eissfeller et al. 2013) or as secondary decomposers feeding predominantly on fungi (Schneider et al. 2004; Pollierer et al. 2012). However, these studies were performed in forests, where litter resources are more important than in pastures, where mown grass is removed after cutting. Fitting to this interpretation, Crotty et al. (2011) presumed poduromorph Collembola to shift trophic niches acting as primary decomposers in grassland but as secondary decomposers in woodland. 
Concentrations of glucose $C$ were lowest in $P$. armata, indicating that this species feeds little on microorganisms but rather on litter or roots and associated mycorrhiza. Direct feeding on roots of Protaphorura species have been shown previously (Larsen et al. 2007; Endlweber et al. 2009), whereas other experiments showed $P$. armata to also feed on fungi and even nematodes (Jørgensen et al. 2003; Scheu and Simmerling 2004; Jørgensen et al. 2005; Heidemann et al. 2014). Our results suggest that in grassland root feeding predominates.

Temporal variations in the incorporation of glucose $C$

Investigating the incorporation of glucose $\mathrm{C}$ into soil microorganisms Lemanski and Scheu (2014) found the amount of ${ }^{13} \mathrm{C}$ from glucose in bacteria to remain at a similar level over a period of 52 weeks, whereas in saprotrophic fungi it was high initially but then decreased fast. Considering these dynamics, species associated with the fungal energy channel are expected to have high initial $\Delta^{13} \mathrm{C}$ signature decreasing fast with time to almost nil after 18 weeks; this pattern resembles that of $L$. lanuginosus and L. cyaneus suggesting that they heavily rely on fungal food. This is in line with studies suggesting Lepidocyrtus species to predominantly feed on microorganisms in particular fungi (Chahartaghi et al. 2005; Pollierer et al. 2012).

Temporal changes in concentrations of glucose $C$ in $L$. similis and E. plicatus were similar to those of the two Lepidocyrtus species, but the incorporation of glucose $\mathrm{C}$ was slower, presumably reflecting the slower life cycle and stronger sclerotization of oribatid mites as compared to collembolans (Mitchell 1977; Behan-Pelletier 2003). The dynamics of incorporation of glucose $\mathrm{C}$ into $P$. peltifer, the third oribatid mite species studied, deviated from that of the other two species as it was much more constant with concentrations of glucose $C$ decreasing slowly after six weeks. This suggests that this species more heavily relies on bacterial food rather than on fungi. This is in contrast to recent studies suggesting that in forests $P$. peltifer mainly feeds on leaf litter and fungi (Pollierer et al. 2009, 2012; Eissfeller et al. 2013). Potentially, P. peltifer switches to bacteria dominated food resources in grassland where, in contrast to forests, organic layers colonized predominantly by fungi are poorly developed (see above).

Mesostigmatid mites (Uropodina and Gamasina) are among the most important predatory soil arthropods (Ruf and Beck 2005; Klarner et al. 2013). Uropodid mites are assumed to predominantly feed on nematodes, whereas gamasid mites are assumed to feed on larger animals, such as collembolans, insect larvae and enchytraeid worms (Karg 1993; Koehler 1999). 
Both of the studied mesostigmatid mites, P. laeuchlii (Gamasina) and U. minima (Uropodina), have been assumed to predominantly feed on secondary decomposers (Klarner et al. 2013). Concentrations of glucose $\mathrm{C}$ in $\mathrm{P}$. laeuchlii decreased moderately with time indicating that it predominantly feeds on bacterial feeding prey species such as bacterial feeding nematodes. Concentrations of glucose $\mathrm{C}$ into U. minima peaked after 18 weeks, presumably reflecting low tissue turnover rate of uropodid mites (Koehler 1999). Earlier studies found predatory mites to pick up the $\mathrm{C}$ signal from labelled resources quickly but changes in the incorporation of $\mathrm{C}$ from these resources have only been followed for 3 days to 4 weeks (Ruf et al. 2006; Strickland et al. 2012). In our study, incorporation of glucose C into U. minima also started early in the experiment but then continued to increase until week 18 suggesting that this species also is closely associated with the bacterial channel, presumably via feeding on bacterial feeding nematodes. Association of both of the studied mesostigmatid mite species with the bacterial channel supports the suggestion that mesostigmatid mite species reaching high density predominantly feed on nematodes (Klarner et al. 2013), with the results of our study indicating that the nematodes consumed comprise mainly of bacterial feeding species.

\section{Variation in incorporation of glucose $\mathrm{C}$ with fertilizer addition and sward composition}

Generally, the addition of fertilizer decreased concentrations and amounts of glucose $\mathrm{C}$ in soil animal species. As at our study site the addition of fertilizer has been shown to little affect the amount of glucose $\mathrm{C}$ in microorganisms but to reduce total microbial biomass (Lemanski and Scheu 2014), decreased incorporation of glucose C into soil animals likely was due to reduced availability of microbial biomass as food rather than reduced amount of glucose $\mathrm{C}$ in microorganisms. As suggested earlier, detritivorous soil animals may switch diet if resources become scarce or more palatable resources become available (Scheu and Folger 2004; Endlweber et al. 2009). Lower concentrations of glucose $C$ in soil animals suggest that they switched towards incorporation of non-labelled resources, presumably by feeding on roots, i.e. by switching from functioning as decomposers towards functioning as herbivores. Generally, reduced incorporation of glucose $\mathrm{C}$ into soil animals in fertilized treatments suggests that fertilizer addition weakens trophic links between microorganisms and microbial grazers. Reduced amount of glucose $\mathrm{C}$ in soil animal populations further suggests that fertilizer addition reduces the flux of microbial $\mathrm{C}$ to higher trophic levels. In particular this applied to microbial 
feeding species such as L. similis and P. peltifer. Notably, the abundance of soil invertebrates was little affected by fertilizer addition; only the abundance of $L$. similis and $P$. peltifer declined in fertilized plots. Low abundance and biomass of L. similis and P. peltifer was associated by low incorporation of glucose $\mathrm{C}$ in fertilized treatments supporting our conclusion that fertilizer addition lessens the flux of microbial $\mathrm{C}$ into the soil food web and into higher trophic levels. Overall, the results indicate that via favouring root feeding fertilization strengthens the herbivore as compared to the decomposer channel. This resembles the aboveground system where increased nutrient supply increases plant nutrient concentrations (Reich et al. 2001; Gruner et al. 2008), thereby favouring herbivores and increasing herbivory, i.e. the use of live plant tissue by consumers (Haddad et al. 2000). Presumably, similar to aboveground food webs, plant nutritional status is a key factor inducing shifts in the diet of decomposer animals towards more intensive root feeding.

In contrast to the addition of fertilizer, differences in sward composition did not affect the incorporation of glucose $\mathrm{C}$ into the soil animal food web which is in accordance with our previous study showing only minor effects of sward composition on the structure of soil microbial communities and their incorporation of glucose C (Lemanski and Scheu 2014). Notably, however, the herbicide-induced changes in sward composition were small, presumably due to the fact that herbicide application stopped in 2008 (see Keuter et al. 2014).

Overall, results of the study suggest that easily available C resources, such as glucose, and the associated incorporation of these resources into microorganisms are of prime importance for fuelling soil food webs. This supports the increasing evidence that belowground systems heavily rely on root exudates as $\mathrm{C}$ source. Each of the studied soil animal species incorporated glucose C, indicating that the majority of grassland soil animal species rely on microorganisms as food resources with microorganisms being fuelled by root exudates. However, incorporation of glucose $C$ into soil animal species varied markedly between species suggesting that detritivorous microarthropods complement each other in channelling microbial C through soil food webs. Reduced incorporation of glucose $C$ into the soil food web with fertilizer addition suggests that fertilizer, addition lessens the link between microorganisms and microbial grazers thereby hampering the propagation of microbial $C$ to higher trophic levels. Reduced concentrations of glucose $\mathrm{C}$ in microarthropods due to fertilizer addition suggest increased root 
feeding and flux of $\mathrm{C}$ of live root into the soil food web resembling increased herbivory due to increased plant tissue nutrient concentrations.

\section{Acknowledgments}

The study formed part of the Cluster of Excellence 'Functional Biodiversity Research' funded by the Ministry of Science and Culture of Lower Saxony and the 'Niedersächsisches Vorab'. We thank Mark Maraun for advice in data analysis, as well as Georgia Erdmann, Christel Fischer, Bernhard Klarner and Nicole Scheunemann for help in sorting and identifying species. Special thanks to Odette Gonzalez for support in determining Collembola.

\section{References}

Albers D, Schaefer M, Scheu S (2006) Incorporation of plant carbon into the soil animal food web of an arable system. Ecology 87, 235-245.

Behan-Pelletier V (2003) Acari and Collembola biodiversity in Canadian agricultural soils. Canadian Journal of Soil Science 83,279-288.

Chahartaghi M, Langel R, Scheu S, Ruess L (2005) Feeding guilds in Collembola based on nitrogen stable isotope ratios. Soil Biology and Biochemistry 37, 1718-1725.

Crotty F V, Blackshaw RP, Murray PJ (2011) Tracking the flow of bacterially derived ${ }^{13} \mathrm{C}$ and ${ }^{15} \mathrm{~N}$ through soil faunal feeding channels. Rapid Communications in Mass Spectrometry 25, 1503-1513.

Eisenhauer N, Cesarz S, Koller R, Worm K, Reich PB (2012) Global change belowground: impacts of elevated $\mathrm{CO}_{2}$, nitrogen, and summer drought on soil food webs and biodiversity. Global Change Biology 18, 435-447.

Eissfeller V, Beyer F, Valtanen K, Hertel, D, Maraun M, Polle A, Scheu S (2013) Incorporation of plant carbon and microbial nitrogen into the rhizosphere food web of beech and ash. Soil Biology and Biochemistry 62, 76-81.

Eitzinger B, Micic A, Körner M, Traugott M, Scheu S (2013) Unveiling soil food web links: New PCR assays for detection of prey DNA in the gut of soil arthropod predators. Soil Biology and Biochemistry 57, 943-945.

Endlweber K, Ruess L, Scheu S (2009) Collembola switch diet in presence of plant roots thereby functioning as herbivores. Soil Biology and Biochemistry 41, 1151-1154. 
Ferlian O, Scheu S, Pollierer MM (2012) Trophic interactions in centipedes (Chilopoda, Myriapoda) as indicated by fatty acid patterns: Variations with life stage, forest age and season. Soil Biology and Biochemistry 52, 33-42.

Grayston SJ, Wang S, Campbell CD, Edwards AC (1998) Selective influence of plant species on microbial diversity in the rhizosphere. Soil Biology and Biochemistry 30, 369-378.

Gruner DS, Smith JE, Seabloom EW, Sandin SA, Ngai JT, Hillebrand H, Harpole,WS, Elser JJ, Cleland EE, Bracken MES, Borer ET, Bolker BM, (2008) A cross-system synthesis of consumer and nutrient resource control on producer biomass. Ecology Letters 11, 74055.

Haddad NM, Haarstad J, Tilman D (2000) The effects of long-term nitrogen loading on grassland insect communities. Oecologia 124, 73-84.

Harpole WS, Tilman D (2007) Grassland species loss resulting from reduced niche dimension. Nature 446, 791-793.

Heidemann K, Hennies A, Schakowske J, Blumenberg L, Ruess L, Scheu S, Maraun M (2014) Free-living nematodes as prey for higher trophic levels of forest soil food webs. Oikos. doi: 10.1111/j.1600-0706.2013.00872.x

Hodge A, Grayston S, Ord B (1996) A novel method for characterisation and quantification of plant root exudates. Plant and Soil 148, 97-104.

Högberg MN, Briones MJI, Keel SG, Metcalfe DB, Campbell C, Midwood AJ, Thornton B, Hurry V, Linder S, Näsholm T, Högberg P (2010) Quantification of effects of season and nitrogen supply on tree below-ground carbon transfer to ectomycorrhizal fungi and other soil organisms in a boreal pine forest. New Phytologist 187, 485-493.

Holland JN, Cheng W, Crossley DA (1996) Herbivore-induced changes in plant carbon allocation: assessment of below-ground C fluxes using carbon-14 Oecologia 107, 87-94.

Isselstein J, Jeangros B, Pavlu V (2005) Agronomic aspects of biodiversity targeted management of temperate grasslands in Europe - A review. Agronomy Research 3, 139-151.

Jones MB, Donnelly A (2004) Carbon sequestration in temperate grassland ecosystems and the influence of management, climate and elevated $\mathrm{CO}_{2}$. New Phytologist 164, 423-439.

Jørgensen HB, Elmholt S, Petersen H (2003) Collembolan dietary specialisation on soil grown fungi. Biology and Fertility of Soils 39, 9-15.

Jørgensen HB, Johansson T, Canbäck B, Hedlund K, Tunlid A (2005) Selective foraging of fungi by collembolans in soil. Biology Letters 1, 243-246.

Karg W (1993) Acari (Acarina), Milben. Parasitiformes (Anactinochaeta). Cohors Gamasina Leach. Raubmilben, second. Gustav Fischer, Jena. 
Kempson D, Lloyd M, Ghelardi R (1963) A new extractor for woodland litter. Pedobiologia 3, 121.

Keuter A, Veldkamp E, Corre MD (2014) Asymbiotic biological nitrogen fixation in a temperate grassland as affected by management practices. Soil Biology and Biochemistry 70, 38-46.

Klarner B, Maraun M, Scheu S (2013) Trophic diversity and niche partitioning in a species rich predator guild - Natural variations in stable isotope ratios $\left({ }^{13} \mathrm{C} /{ }^{12} \mathrm{C},{ }^{15} \mathrm{~N} /{ }^{14} \mathrm{~N}\right)$ of mesostigmatid mites ( Acari, Mesostigmata) from Central European beech forests. Soil Biology and Biochemistry 57, 327-333.

Koehler HH (1999) Predatory mites (Gamasina, Mesostigmata). Agriculture, Ecosystems and Environment74, 395-410.

Langel R, Dyckmans J (2014) Combined C-13 and N-15 isotope analysis on small samples using a near-conventional elemental analyzer/isotope ratio mass spectrometer setup. Rapid Communications in Mass Spectrometry 28, 1019-1022.

Larsen T, Gorissen A, Krogh PH, Ventura M, Magid J (2007) Assimilation dynamics of soil carbon and nitrogen by wheat roots and Collembola. Plant and Soil 295, 253-264.

Lemanski K, Scheu S (2014) Incorporation of ${ }^{13} \mathrm{C}$ labelled glucose into soil microorganisms of grassland: Effects of fertilizer addition and plant functional group composition. Soil Biology and Biochemistry 69, 38-45.

Mitchell M (1977) Life history strategies of oribatid mites. In: Dindal DL (ed) Biology of Oribatid Mites. State University, New York, pp 65-69.

Ostle N, Briones MJI, Ineson P, Cole L, Staddon P, Sleep D (2007) Isotopic detection of recent photosynthate carbon flow into grassland rhizosphere fauna. Soil Biology and Biochemistry 39, 768-777.

Petersen U, Wrage N, Köhler L, Leuschner C, Isselstein J (2012) Manipulating the species composition of permanent grasslands-A new approach to biodiversity experiments. Basic and Applied Ecology 13, 1-9.

Pollierer MM, Dyckmans J, Scheu S, Haubert D (2012) Carbon flux through fungi and bacteria into the forest soil animal food web as indicated by compound-specific ${ }^{13} \mathrm{C}$ fatty acid analysis. Functional Ecology 26, 978-990.

Pollierer MM, Langel R, Körner C, Maraun M, Scheu S (2007) The underestimated importance of belowground carbon input for forest soil animal food webs. Ecology Letters 10, 729736. 
Pollierer MM, Langel R, Scheu S, Maraun M (2009) Compartmentalization of the soil animal food web as indicated by dual analysis of stable isotope ratios $\left({ }^{15} \mathrm{~N} /{ }^{14} \mathrm{~N}\right.$ and $\left.{ }^{13} \mathrm{C} /{ }^{12} \mathrm{C}\right)$. Soil Biology and Biochemistry 41, 1221-1226.

Post D (2002) Using stable isotopes to estimate trophic position: models, methods, and assumptions. Ecology 83, 703-718.

Post WM, Kwon KC (2000) Soil carbon sequestration and land-use change: processes and potential. Global Change Biology 6, 317-327.

Reich PB, Knops J, Tilman D, Craine J, Ellsworth D, Tjoelker M, Lee T, Wedin D, Naeem S, Bahauddin D, Hendrey G, Jose S,Wrage K, Goth J, Bengston W (2001) Plant diversity enhances ecosystem responses to elevated $\mathrm{CO}_{2}$ and nitrogen deposition. Nature 410, 809-812.

Reid JP, Adair EC, Hobbie SE, Reich PB (2012) Biodiversity, Nitrogen Deposition, and $\mathrm{CO}_{2}$ Affect Grassland Soil Carbon Cycling but not Storage. Ecosystems 15, 580-590.

Rose L, Coners H, Leuschner C (2012) Effects of fertilization and cutting frequency on the water balance of a temperate grassland. Ecohydrology 5, 64-72.

Ruf $A$, Beck $L$ (2005) The use of predatory soil mites in ecological soil classification and assessment concepts, with perspectives for oribatid mites. Ecotoxicology and Environmental Safety 62, 290-299.

Ruf A, Kuzyakov Y, Lopatovskaya O (2006) Carbon fluxes in soil food webs of increasing complexity revealed by ${ }^{14} \mathrm{C}$ labelling and ${ }^{13} \mathrm{C}$ natural abundance. Soil Biology and Biochemistry 38, 2390-2400.

Sala O, Chapin F, Armesto J J, Berlow E, Bloomfield J, Dirzo R, Huber-Sanwald E, Huenneke LF, Jackson RB, Kinzig A, Leemans R, Lodge DM, Mooney HA, Oesterheld M, Poff NL, Sykes MT, Walker BH, Walker M, Wall DH (2000) Global biodiversity scenarios for the year 2100. Science 287, 1770-1774.

Scheu S (2002) The soil food web: structure and perspectives. European Journal of Soil Biology $38,11-20$

Scheu S, Falca M (2000) The soil food web of two beech forests (Fagus sy/vatica) of contrasting humus type: stable isotope analysis of a macro- and a mesofauna-dominated community. Oecologia 123, 285-296.

Scheu S, Folger M (2004) Single and mixed diets in Collembola: effects on reproduction and stable isotope fractionation. Functional Ecology 18, 94-102.

Scheu S, Simmerling F (2004) Growth and reproduction of fungal feeding Collembola as affected by fungal species, melanin and mixed diets. Oecologia 139, 347-353. 
Schneider K, Migge S, Norton RA, Scheu S, Langel R, Reineking A, Maraun M (2004) Trophic niche differentiation in soil microarthropods (Oribatida, Acari): evidence from stable isotope ratios $\left({ }^{15} \mathrm{~N} /{ }^{14} \mathrm{~N}\right)$. Soil Biology and Biochemistry 36, 1769-1774.

Siemann E (1998) Experimental tests of effects of plant productivity and diversity on grassland arthropod diversity. Ecology 79, 2057-2070.

Strickland MS, Wickings K, Bradford MA (2012) The fate of glucose, a low molecular weight compound of root exudates, in the belowground foodweb of forests and pastures. Soil Biology and Biochemistry 49, 23-29.

Suding KN, Collins SL, Gough L, Clark C, Cleland EE, Gross KL, Milchunas DG, Pennings S (2005) Functional- and abundance-based mechanisms explain diversity loss due to $\mathrm{N}$ fertilization. Proceedings of the National Academy of Sciences of the United States of America 102, 4387-4392.

Tiunov A (2007) Stable isotopes of carbon and nitrogen in soil ecological studies. Biology Bulletin 34, 395-407.

Vanderklift $\mathrm{M}$ a, Ponsard S (2003) Sources of variation in consumer-diet delta ${ }^{15} \mathrm{~N}$ enrichment: a meta-analysis. Oecologia 136, 169-82.

Vitousek P, Mooney H, Lubchenco J, Melillo J (1997) Human domination of Earth's ecosystems. Science 7 494-499.

Werner R, Bruch B, Brand W (1999) ConFlo III - An interface for high precision $\delta^{13} \mathrm{C}$ and $\delta^{15} \mathrm{~N}$ analysis with an extended dynamic range. Rapid Communications in Mass Spectrometry $13,1237-1241$. 


\section{Chapter 5}

General Discussion

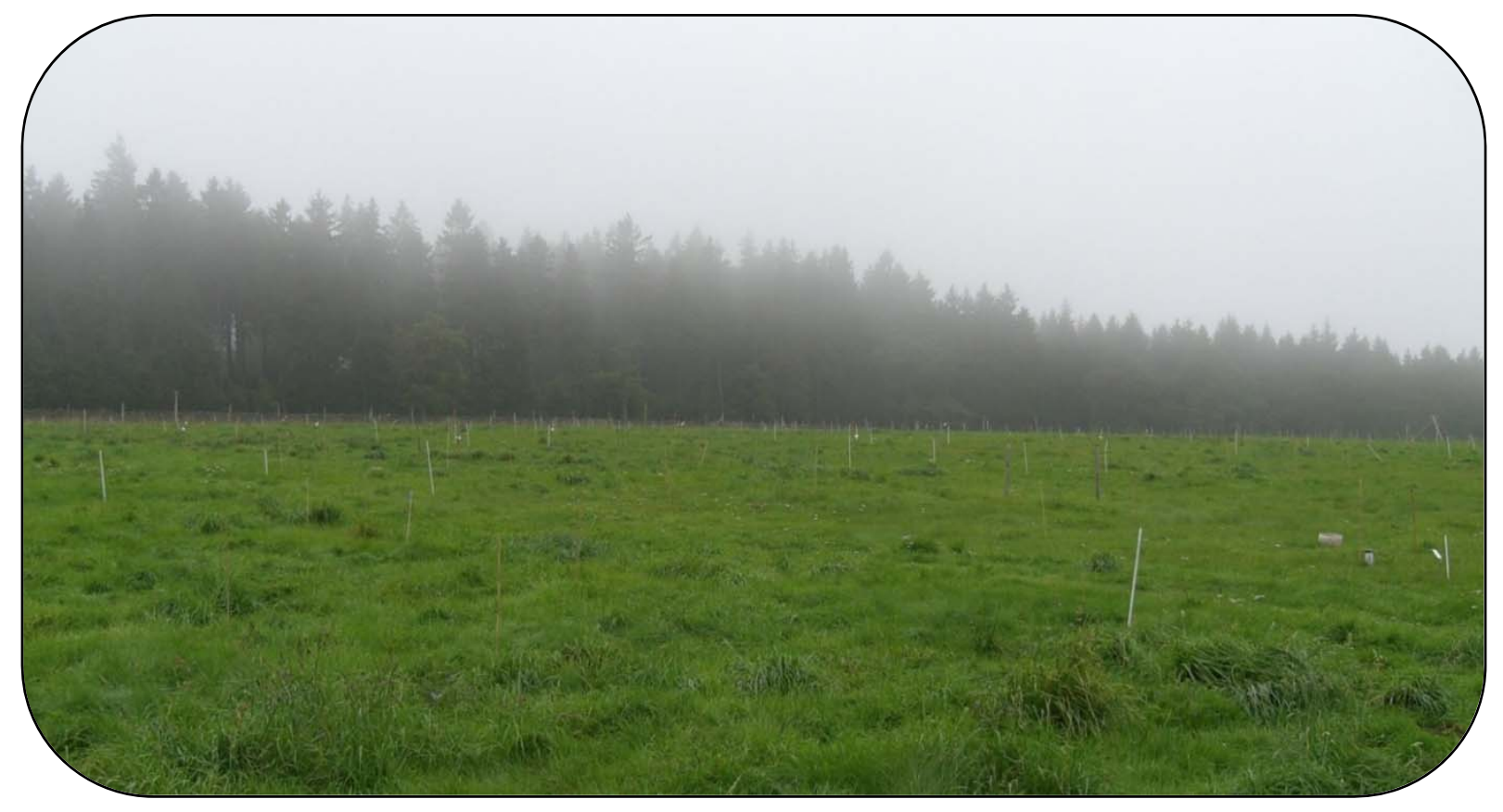


This thesis presents major advances in understanding the influence of agricultural management on soil biota and the $\mathrm{C}$ flux within belowground food webs. I took advantage of the GRASSMANN-Experiment, representing a gradient in agricultural management including fertilizer addition, cutting frequency and sward composition in a temperate grassland. Fertilizer application was identified as strongest impact on soil organisms suggesting to lessening the root derived C path into soil food webs, but to strengthen the herbivore one. Furthermore, the established concept of a slow fungal and fast bacterial energy channel is challenged, as this study shows fungi to have a faster incorporation of glucose $\mathrm{C}$ than bacteria in relative terms.

\section{Microbial community composition}

The studies described in chapters 2 and 3 show that microbial biomass $\left(C_{\text {mic }}\right)$ and communities react sensitively to management treatments. In the first study (chapter 2) $C_{\text {mic }}$ decreased in treatments cut once combined with fertilizer addition. However, in treatments with three cuts, $\mathrm{C}_{\text {mic }}$ did not decline with fertilizer addition, suggesting that cutting frequency lessens the adverse effect of fertilizer input. The second study (chapter 3 ), conducted roughly a year later with repeated sampling, supports the negative effect of fertilizer on $\mathrm{C}_{\text {mic }}$ (cutting frequency was not considered in this study). Beneficial effects of defoliation and adverse effects of $\mathrm{N}$ fertilization on $\mathrm{C}_{\text {mic }}$ in grasslands have been reported previously (Mawdsley and Bardgett 1997; de Vries et al. 2007). Assuming that $C_{\text {mic }}$ is correlated with $C$ released by roots (Darrah 1991), both treatment effects may be linked to root exudation whereby defoliation is suggested to increase root $C$ release (Holland et al. 1996; Paterson et al. 2003). In contrast, fertilization has been documented to reduce belowground C allocation (Bazot et al. 2006). In our study (chapter 3) both $\mathrm{C}_{\text {mic }}$ and $\mathrm{AM}$ (arbuscular mycorrhiza) fungi declined with fertilization, suggesting that to cover the demand of nutrients in non-fertilized treatments plants more heavily invest in mycorrhizal symbionts; likely associated with an increase in C allocation to roots and increased $\mathrm{C}$ input into the rhizosphere. Low abundance of AM fungi in fertilized grassland has been reported previously (Denef et al. 2009; Son and Smith 1988), and it has been suggested that $N$ fertilization disrupts the relationship between AM fungi and plants (Bradley et al. 2006).

In both studies (chapter 2 and 3), a higher proportion of fungi was associated with reduced proportions of monocots. This is in line with Smith et al. (2008) who found the fungal-to- 
bacterial ratio to be higher in swards dominated by forbs including legumes. In contrast, Lange et al. (2014) found legumes to decrease fungal biomass. Bacterial PLFA biomarkers did not vary with sward composition, indicating that fungi respond more sensitively to changes in plant functional group composition as compared to bacteria.

\section{Microbial incorporation of glucose $\mathrm{C}$}

Results of the second study (chapter 3 ) documented the flux of $\mathrm{C}$ into microorganisms using ${ }^{13} \mathrm{C}$ labelled glucose, mimicking root exudates, over a period of one year. In fertilized treatments the fungal-to-bacterial ${ }^{13} \mathrm{C}$ ratio increased, whilst bacterial ${ }^{13} \mathrm{C}$ incorporation remained at the same level, suggesting that fertilizer addition increases the efficiency of resource capture by fungi but not by bacteria. In contrast, Denef et al. (2009) documented a decreased enrichment of ${ }^{13} \mathrm{C}$ in fungal PLFA with $\mathrm{N}$ fertilization. Results of both studies (chapter 2 and 3 ) emphasize the sensitivity of fungi to changes in management as compared to bacteria.

Notably, the fungal-to-bacterial atom percent excess ratio of PLFAs exceeded 1 in the first two sampling dates, after two and six weeks, indicating higher ${ }^{13} \mathrm{C}$ concentration in fungal as compared to bacterial PLFAs, while at later sampling dates the opposite was the case. This suggests that, in relative terms, fungi are initially more efficient in capturing low molecular weight $\mathrm{C}$ compounds entering the soil in pulses than bacteria, which challenges the idea of a slow fungal and a fast bacterial channel. Our findings are supported by other recent studies, which found $\mathrm{C}$ from pulse labelling of plants with ${ }^{13} \mathrm{CO}_{2}$ to be incorporated predominantly into fungi, underlining the ability of fungi to efficiently exploit low molecular weight organic substances, such as root exudates (Butler et al. 2003; Denef et al. 2009). Denef et al. (2007) postulated a fungi-mediated transfer of root derived $\mathrm{C}$ to bacterial communities from fungal residues or dead root material rather than from fresh root exudates. This idea is supported by our finding that the capacity to incorporate glucose $\mathrm{C}$ into fungi is most pronounced soon (two and six weeks) after glucose addition and declines at later stages, whereas the incorporation of glucose C into bacteria varies little with time, at least over a period of one year. Therefore, microbial residues indeed presumably are processed predominantly by bacteria not by fungi. 


\section{Animal abundances}

In the first study (chapter 2), the abundance of entomobryid collembolllans and in trend oribatid mites declined with fertilizer addition, which is supported by results of the third study (chapter 4), where biomass of the oribatid mites L. similis and P. peltifer were lower in fertilized treatments. Interestingly, most of these animals are secondary decomposers relying on microorganisms as food resource (Chahartaghi et al. 2005; Schneider and Maraun 2005; Maraun et al. 2011). The decline in abundances of these groups therefore likely was due to reduced $\mathrm{C}_{\mathrm{mic}}$ in fertilized treatments. In contrast, abundances of dipterans and beetles increased with fertilizer addition but decreased with cutting frequency. Frouz (1999) reported the number of dipteran larvae to increase with increased plant litter input, suggesting dipterans to benefit from higher resource supply, e.g. due to increased plant biomass. This is consistent with results of the present study and suggests that the increase in abundance of dipterans was mainly due to detritivorous species. The majority of beetles comprised Staphylinidae which typically live as generalist predators feeding on small arthropods (Bohac 1999). As the abundance of microarthropods was hardly affected by experimental treatments, variations in the abundance of beetles likely were due to changes in the abundance of dipteran larvae. However, Staphylinidae may also have benefited from denser vegetation in treatments with fertilizer addition and cut only once per year as they prefer shaded microhabitats and benefit from improved overwintering conditions (Bohac 1999; Collins et al. 2003; Dauber et al. 2005). Considering feeding strategies suggests that taxa directly feeding on plant material, either as herbivores or litter feeders, benefit from fertilization. In contrast, those associated with root exudates are negatively affected.

Overall, the results of both studies (chapter 3 and 4 ) indicate that examined soil invertebrate communities are rather insensitive to variations in grassland management practices, as the majority of taxa did not respond to experimental treatments. Similarly, earlier studies reported inconsistent responses of soil invertebrates to $\mathrm{N}$ fertilization with increases or decreases in abundances typically being limited to certain taxa and most taxa being unresponsive (Bardgett and Cook 1998; Cole et al. 2006; Eisenhauer et al. 2013). Notably, the effect of management was most striking at the bottom of the food web, i.e., in microorganisms, invertebrates consisting of primary and secondary decomposers and only little in predators suggesting that management effects diminish at higher trophic levels. 


\section{Incorporation of glucose $\mathrm{C}$ into animals}

Results of the third study (chapter 4) documented the $\mathrm{C}$ flux into soil invertebrates using ${ }^{13} \mathrm{C}$ labelled glucose, simulating root exudates via microorganisms. Notably, all examined soil animal species incorporated glucose $\mathrm{C}$ suggesting that all of them at least partially rely on microorganisms as food resources. However, incorporation of glucose $\mathrm{C}$ into soil animal species varied markedly with species identity. Due to the different amounts and temporal patterns of incorporation of glucose C, I was able to ascribe individual species to distinct food resources. Species feeding on root exudates associated microorganisms have high ${ }^{13} \mathrm{C}$ incorporation, whereas species relying on litter or roots and associated mycorrhiza have low ${ }^{13} \mathrm{C}$ incorporation. Furthermore, the particular temporal pattern of incorporation of glucose $\mathrm{C}$ into fungi and bacteria (chapter 3) enabled us to differentiate between species feeding on fungi or on bacteria. For example, both Lepidocyrtus species initially had a high ${ }^{13} \mathrm{C}$ incorporation, which declined quickly to almost nil suggesting that they heavily rely on fungi as food resources. In contrast, $P$. armata had very low ${ }^{13} \mathrm{C}$ incorporation over the whole year suggesting this species to feed directly on plant material. Those distinct incorporation patterns stress the complementarity of microarthropod species in channelling $C$ through soil food webs.

Fertilization reduced concentrations of glucose $\mathrm{C}$ incorporation in most microarthropods suggesting that fertilizer addition shifts the basis of the decomposer food web towards utilization of unlabelled resources, presumably roots, i.e. towards a herbivore system, thereby lessening the link between microorganisms and microbial grazers and hampering the propagation of microbial $\mathrm{C}$ to higher trophic levels. Consistent with these findings previous studies suggested that soil animals switch to other diets when resources become scarce or more palatable resources become available (Scheu and Folger 2004; Endlweber et al. 2009). Overall, the results indicate that fertilization strengthens herbivores feeding on roots as compared to those animals feeding as secondary decomposer on microorganisms, which is in line with results of the first study (chapter 2).

Differences in sward composition hardly affected glucose $\mathrm{C}$ incorporation, neither into microorganisms nor into soil animals (chapter 3 and 4), presumably because herbicide-induced changes in sward composition were limited due to the fact that herbicides were only applied once in 2008. 


\section{Conclusion}

Overall, this thesis documents the faster incorporation of glucose $\mathrm{C}$ into fungi in comparison to bacteria, challenging the idea of a slow fungal and a fast bacterial channel. Fertilizer addition reduced $\mathrm{C}_{\mathrm{mic}}$ and abundances of secondary decomposers, presumably due to decreased root exudation, which serves as food resource for microorganisms, which in turn are key resources for secondary decomposers. In contrast to organisms relying on root exudates, animals relying directly on plant material, either as herbivores or as litter feeders, benefited from fertilizer addition as it resulted in higher biomass and higher nutritional status of plants. Soil animals are suggested to switch diet if resources become scarce or more palatable resources become available.

These results advanced the understanding of soil food web structure and its role in managed grassland. They document the value of innovative techniques, especially stable isotope analysis using glucose as ${ }^{13} \mathrm{C}$ tracer. The combination of stable isotope analysis, fatty acid analysis and compound specific ${ }^{13} \mathrm{C}$ analyses provide a powerful tool for studying the structure and the flux of $\mathrm{C}$ through the bacterial and fungal channel of grassland and terrestrial ecosystems in general.

\section{References}

Bardgett RD, Cook R (1998) Functional aspects of soil animal diversity in agricultural grasslands. Applied Soil Ecology 10, 263-276.

Bazot S, Ulff L, Blum H, Nguyen C, Robin C (2006) Effects of elevated $\mathrm{CO}_{2}$ concentration on rhizodeposition from Lolium perenne grown on soil exposed to 9 years of $\mathrm{CO}_{2}$ enrichment. Soil Biology and Biochemistry 38, 729-736.

Bohac J (1999) Staphylinid beetles as bioindicators. Agriculture, Ecosystems and Environment 74, 357-372.

Bradley K, Drijber RA, Knops J (2006) Increased N availability in grassland soils modifies their microbial communities and decreases the abundance of arbuscular mycorrhizal fungi. Soil Biology and Biochemistry 38, 1583-1595.

Butler JL, Williams MA, Bottomley PJ, Myrold DD (2003) Microbial community dynamics associated with rhizosphere carbon flow. Applied and Environmental Microbiology 69, 6793-6800. 
Chahartaghi M, Langel R, Scheu S, Ruess L (2005) Feeding guilds in Collembola based on nitrogen stable isotope ratios. Soil Biology and Biochemistry 37, 1718-1725.

Cole L, Bradford MA, Shaw PJA, Bardgett RD (2006) The abundance, richness and functional role of soil meso- and macrofauna in temperate grassland-A case study. Applied Soil Ecology 33, 186-198.

Collins KL, Boatman ND, Wilcox A, Holland JM (2003) Effects of different grass treatments used to create overwintering habitat for predatory arthropods on arable farmland. Agriculture, Ecosystems and Environment 96, 59-67.

Darrah P (1991) Models of rhizosphere II. A quasi three-dimensional simulation of the microbial population dynamics around a growing root releasing soluble exudates. Plant Soil 138, 147-158.

Dauber J, Purtauf T, Allspach A, Frisch J, Voigtländer K, Wolters V (2005) Local vs . Iandscape controls on diversity: a test using surface-dwelling soil macroinvertebrates of differing mobility. Global Ecology and Biogeography 14, 213-221.

De Vries FT, Bloem J, van Eekeren N, Brusaard L, Hoffland E (2007) Fungal biomass in pastures increases with age and reduced $\mathrm{N}$ input. Soil Biology and Biochemistry 39, 1620-1630.

Denef K, Bubenheim H, Lenhart K, Vermeulen J, van Cleemput O, Boeckx P, Müller C (2007) Community shifts and carbon translocation within metabolically-active rhizosphere microorganisms in grasslands under elevated $\mathrm{CO}_{2}$. Biogeoscience 4, 769-779.

Denef K, Roobroeck D, Manimel Wadu MCW, Lootens P, Boeckx P (2009) Microbial community composition and rhizodeposit-carbon assimilation in differently managed temperate grassland soils. Soil Biology and Biochemistry 41, 144-153.

Eisenhauer N, Dobies T, Cesarz S, Hobbie SE, Meyer RJ, Worm K, Reich PB (2013) Plant diversity effects on soil food webs are stronger than those of elevated $\mathrm{CO}_{2}$ and $\mathrm{N}$ deposition in a long-term grassland experiment. Proceedings of the National Academy of Sciences 110, 6889-6894.

Endlweber K, Ruess L, Scheu S (2009) Collembola switch diet in presence of plant roots thereby functioning as herbivores. Soil Biology and Biochemistry 41, 1151-1154.

Frouz J (1999) Use of soil dwelling Diptera (Insecta, Diptera) as bioindicators: a review of ecological requirements and response to disturbance. Agriculture, Ecosystems \& Environment 74, 167-186.

Holland JN, Cheng W, Crossley DA (1996) Herbivore-induced changes in plant carbon allocation: assessment of below-ground C fluxes using carbon-14. Oecologia 107, 87-94.

Lange M, Habekost M, Eisenhauer N, Roscher C, Bessler H, Engels C, Oelmann Y, Scheu S, Wilcke W, Schulze ED, Gleixner G (2014) Biotic and Abiotic Properties Mediating Plant Diversity Effects on Soil Microbial Communities in an Experimental Grassland. PLoS One 9, e96182. 
Maraun M, Erdmann G, Fischer BM, Pollierer MM, Norton R A, Schneider K, Scheu S (2011) Stable isotopes revisited: Their use and limits for oribatid mite trophic ecology. Soil Biology and Biochemistry 43, 877-882.

Mawdsley JL, Bardgett RD (1997) Continuous defoliation of perennial ryegrass (Lolium perenne) and white clover (Trifolium repens) and associated changes in the composition and activity of the microbial population of an upland grassland soil. Biology and Fertility of Soils 24, $52-58$.

Paterson E, Thornton B, Sim A, Pratt S (2003) Effects of defoliation and atmospheric $\mathrm{CO}_{2}$ depletion on nitrate acquisition, and exudation of organic compounds by roots of Festuca rubra. Plant and Soil 250, 293-305.

Scheu S, Folger M (2004) Single and mixed diets in Collembola: effects on reproduction and stable isotope fractionation. Functional Ecology 18, 94-102.

Schneider K, Maraun M (2005) Feeding preferences among dark pigmented fungal taxa ("Dematiacea") indicate limited trophic niche differentiation of oribatid mites (Oribatida, Acari). Pedobiologia 49, 61-67.

Smith RS, Shiel RS, Bardgett RD, Millward D, Corkhill P, Evans P, Quirk H, Hobbs PJ, Kometa ST, (2008) Long-term change in vegetation and soil microbial communities during the phased restoration of traditional meadow grassland. Journal of Applied Ecology 45, 670-679.

Son CL, Smith SE (1988) Mycorrhizal growth responses: interactions between photon irradiance and phosphorus nutrition. New Phytologist 108, 305-314. 


\section{Acknowledgements/Danksagung}

Zu allererst möchte ich Stefan danken. Von seinem enormen Wissen, seinen unermüdlichen Korrekturen und seiner stets offenen Tür habe ich sehr profitiert. Auch werden mir die Exkursionen in die Pyrenäen und nach Giglio unvergesslich bleiben.

Mark danke ich vor allem für die statistische Beratung (und natürlich dafür, dass er in Erwägung gezogen hat mich in die Fußballdiskussionsrunde aufzunehmen), außerdem ihm und auch Teja Tscharntke, weil sie Teil meines Thesis Committees sind.

In die Welt der Fettsäuren hat mich Guido eingeführt. Er stand mir immer mit Rat und Tat zur Seite und ist mir über das Berufliche hinaus ein guter Freund geworden. Des Weiteren bedanke ich mich für das technische Engagement von Christel, Ingrid und Susanne.

Die ganze AG Tierökologie hat mich warmherzig aufgenommen und es war wunderschön, in einem so angenehmen Klima arbeiten zu dürfen. Besonders leicht ist mir der Einstieg natürlich durch die „Collemboladies" Simone, Olga und Georgia gefallen, die immer ein flottes Liedchen auf den Lippen hatten und so manchen Schabernack im Kopf (der meistens auch in die Tat umgesetzt wurde). Euch herzlichen Dank dafür und auch für die kompetente fachliche Unterstützung.

Auch von den „Neuen“ (Odette und Tanja) im Büro bekam ich Unterstützung. Was hätte ich nur ohne Odettes Hilfe bei den Collembolen getan? Vielen Dank!

Von meiner großartigen, etwas verrückten, aber durch und durch liebenswürdigen Patchworkfamilie habe ich stets Unterstützung erfahren. Ich danke euch allen und doch jedem/jeder auf spezielle Art!

Über die langjährigen Freundschaften mit Tarek, Leni, Claudi und Eric bin ich einfach nur glücklich. Ebenso über neu gewonnene Freundschaften wie die mit Merle, Torben und Marleen, die mir allesamt zeigten, dass es neben der Arbeit noch einen Haufen Spaß gibt. Danke, dass es Euch gibt!

Ganz besonderen Dank natürlich meinem Freund Bastian, der es immer wieder schafft mich die Leichtigkeit finden zu lassen, die ich zum Arbeiten und zum Leben brauche. 


\section{List of publications}

\section{Published in peer-reviewed journals:}

Lemanski K, Scheu S (2014) Incorporation of ${ }^{13} \mathrm{C}$ labelled glucose into soil microorganisms of grassland: Effects of fertilizer addition and plant functional group composition. Soil Biology and Biochemistry 69, 38-45.

Lemanski K, Scheu S (2014) Fertilizer addition lessens the flux of microbial carbon to higher trophic levels in soil food webs of grassland. Oecologia 176, 487-496.

Lemanski K, Scheu S. Influence of fertilizer addition, cutting frequency and herbicide application on soil organisms in grassland. Biology and Fertility of Soils. doi: 10.1007/s00374-0140963-2. Accepted. 


\section{Thesis declarations}

Chapter 2 comprises a manuscript that is currently submitted to a peer reviewed Journal.

Chapters 3 and 4 comprise manuscripts that have been published in peer-reviewed journals.

In all manuscripts I am the first author and I have analysed the data, written the manuscripts, and developed the main ideas and created tables and figures.

The study design was developed in the framework of the 'GRASSMANN' (Grassland Management) experiment, which forms part of the Cluster of Excellence "Functional Biodiversity Research" (FBR).

\section{Plagiarism Declaration}

I declare that I have written this doctoral thesis independently. All persons contributing to the manuscripts have been named so. All sentences or passages quoted from other people's work have been specifically acknowledged by clear cross-referencing. I have not submitted this thesis in any form for another degree at any university or institution.

Kathleen Lemanski

Göttingen, September 2014 